\title{
LESA verlengde nevengeul Junne
}





\section{LESA verlengde nevengeul Junne}

S.P.J. van Delft, G.J. Maas

Dit onderzoek is uitgevoerd door Wageningen Environmental Research in opdracht van en gefinancierd door het ministerie van Landbouw, Natuur en Voedselkwaliteit in het kader van het Kennisbasis onderzoeksthema 'System Earth Management' (projectnummer KB-24-001-017) en het ministerie van Infrastructuur en Milieu en het waterschap Vechtstromen in het kader van het Programma Lumbricus, onderzoeksthema Boeiende Beekdalen.

Wageningen Environmental Research

Wageningen, december 2018 
Delft, S.P.J. van, G.J. Maas, 2018. Lesa verlengde nevengeul Junne. Wageningen, Wageningen Environmental Research, Rapport 2917. 76 blz.; 31 fig.; 3 tab.; 16 ref.

In blijvend gestuwde systemen kan de aanleg stuw-passerende-nevengeulen een goed alternatief zijn voor beek- en rivierherstel. Het programma 'Ruimte voor de Vecht' voorziet in een verlenging van de bestaande nevengeul Junne volgens het principe 'Bouwen met Natuur'. Onderzoek naar de hydromorfologische ontwerpeisen, maatregelen en het beheer van de nevengeul vindt plaats in het Programma Lumbricus Boeiende Beekdalen Proeftuin Oost. Het doel van de verlenging is een $3250 \mathrm{~m}$ lange, langzaam stromende beek of rivier op zand (KRW-type R6/ R7), nieuw areaal stroomdalgraslanden (N2000-habitattype H6120) en overstromingsmilieus voor KRW-doelsoorten. Landschapsecologische systeemanalyse toont aan dat de kans op laterale geulverleggingen door het cohesieve karakter van de bodem in de oeverzone klein is, maar er een risico is op verticale erosie van de bedding. Voor stroomdalgraslanden, overstromingsmilieus en alluviale bossen zijn er realisatiekansen in het gebied. Deze worden sterk beïnvloed door de verwachte wijziging van de grondwaterstanden als gevolg van de aanleg van de nevengeul.

Trefwoorden: landschapsecologische systeemanalyse, Overijsselse Vecht, rivierherstel, kaderrichtlijn water, natura2000, stroomdalgrasland, nevengeul, bodem, geomorfologie, habitat

Dit rapport is gratis te downloaden van https://doi.org/10.18174/467150 of op www.wur.nl/environmental-research (ga naar 'Wageningen Environmental Research' in de grijze balk onderaan). Wageningen Environmental Research verstrekt geen gedrukte exemplaren van rapporten.

@2 2018 Wageningen Environmental Research (instituut binnen de rechtspersoon Stichting Wageningen Research), Postbus 47, 6700 AA Wageningen, T 0317480700 ,

www.wur.nl/environmental-research. Wageningen Environmental Research is onderdeel van Wageningen University \& Research.

- Overname, verveelvoudiging of openbaarmaking van deze uitgave is toegestaan mits met duidelijke bronvermelding.

- Overname, verveelvoudiging of openbaarmaking is niet toegestaan voor commerciële doeleinden en/of geldelijk gewin.

- Overname, verveelvoudiging of openbaarmaking is niet toegestaan voor die gedeelten van deze uitgave waarvan duidelijk is dat de auteursrechten liggen bij derden en/of zijn voorbehouden.

Wageningen Environmental Research aanvaardt geen aansprakelijkheid voor eventuele schade voortvloeiend uit het gebruik van de resultaten van dit onderzoek of de toepassing van de adviezen.

Wageningen Environmental Research Rapport 2917 | ISSN 1566-7197

Foto omslag: Michaël van Buuren 


\section{Inhoud}

$\begin{array}{ll}\text { Woord vooraf } & 5\end{array}$

$\begin{array}{ll}\text { Samenvatting } & 7\end{array}$

1

$\begin{array}{ll}\text { Inleiding } & 9\end{array}$

1.1 Aanleiding 9

$\begin{array}{lll}1.2 & \text { Onderzoeksvragen } & 11\end{array}$

$\begin{array}{lll}1.3 & \text { Werkwijze } & 12\end{array}$

$\begin{array}{lll}1.4 & \text { Resultaat } & 13\end{array}$

Geologie, landschap en bodem $\quad 14$

2.1 Geologie 14

2.2 Geomorfologische kaart $1890 \quad 14$

$2.3 \quad$ Landschapsontwikkeling sinds $1754 \quad 16$

$\begin{array}{lll}2.4 & \text { Bodemkaart } & 17\end{array}$

$\begin{array}{lll}2.5 & \text { Ondergrond } & 20\end{array}$

$\begin{array}{lll}2.6 & \text { Verwerkte gronden } & 23\end{array}$

$\begin{array}{lll}2.7 & \text { Grondwaterstandverloop } & 26\end{array}$

$\begin{array}{ll}2.8 & \text { Inundatiekarakteristieken } \\ 2.9 & 29\end{array}$

$2.9 \quad$ EGV grond- en oppervlaktewater $\quad 32$

$2.10 \mathrm{pH}$-profiel $\quad 33$

3 Ontwerp nevengeul, bodemsubstraat en grondwatersituatie 36

3.1 Transecten $\quad 36$

3.2 Deeltraject A (transect R1 en R3) 39

3.3 Deeltraject B en C (transect R2) 40

$\begin{array}{lll}3.4 & \text { Conclusies } & 40\end{array}$

4 Landschapsecologische analyse $\quad 41$

$\begin{array}{lll}4.1 & \text { Fysisch-geografische positie } & 41\end{array}$

$\begin{array}{lll}4.2 & \text { Potentiële vegetatieontwikkeling } & 43\end{array}$

$\begin{array}{lll}4.3 & \text { Advies moerassige laagte } & 46\end{array}$

$\begin{array}{lll}4.4 & \text { Huidige situatie } & 46\end{array}$

$4.5 \mathrm{Na}$ inrichting $\quad 51$

$5 \quad$ Conclusie $r 52$

$\begin{array}{ll}\text { Literatuur } & \mathbf{5 4}\end{array}$

Bijlage 1 Landschapsontwikkeling op de kaart 55

$\begin{array}{lll}\text { Bijlage 2 } & \text { Boorpuntenkaart } & 62\end{array}$

$\begin{array}{lll}\text { Bijlage } 3 & \text { Potentiële vegetaties } & 64\end{array}$

Bijlage 4 Kenmerkende plantengemeenschappen habitattypen $\quad 66$

$\begin{array}{lll}\text { Bijlage 5 Methoden voor het bepalen van de realisatiekansen } & 68\end{array}$

Bijlage 6 Realisatiekansen habitattypen $\quad 72$ 



\section{Woord vooraf}

Dit rapport maakt deel uit van het onderzoek dat binnen het Programma Lumbricus, thema Boeiende Beekdalen, pijler Ontwikkelpaden, wordt uitgevoerd in Proeftuin Vecht. De opgave die het thema Boeiende Beekdalen zich stelt, is om met het Lumbricus-doel bij te dragen aan de ontwikkeling van een flexibele en klimaat-robuuste inrichting van beken en beekdalen met de hierbij behorende beheerstrategieën. Daarbij wordt de ervaring met 'Building with Nature'-principes gebruikt. Bouwen met de natuur betekent meer ruimte laten voor en gebruikmaken van natuurlijke processen binnen de kaders die de gebruiksfuncties van de watergang bieden.

De proeftuin Vecht biedt met de ontwikkeling van een verlengde nevengeul Junne een unieke kans om snel en vanaf het begin bij het ontwerp en uitvoering van een bypass betrokken te raken.

De contouren van het ontwerp voor de verlengde nevengeul zijn neergezet in twee ontwerpsessies met inbreng (hydrologie en ecologie) van het waterschap Vechtstromen en begeleid door onderzoekers (toegepaste geomorfologie) en ontwerpers van Wageningen Environmental Research. Het resultaat van deze ontwerpsessies is vertaald naar een definitief ontwerp. Onderdeel van het ontwerpproces was een landschapsecologische systeemanalyse (LESA). Een LESA voorziet in de onmisbare en essentiële informatie van het natuurlijke systeem die nodig is om in het ontwerp ook werkelijk te kunnen 'Bouwen met de natuur'. De vertraging die in de uitvoer van de bypass Junne als gevolg van de MER-plicht is ontstaan, kan ten volle worden benut om op basis van de LESA de realisatiekansen voor de gestelde doelen op waarde te schatten en de maatregelen zo nodig daaraan bij te stellen.

Gilbert Maas en Bas van Delft 


\section{Samenvatting}

Een goed alternatief voor beek- en rivierherstel in blijvend gestuwde systemen kan de aanleg van stuw-passerende-nevengeulen zijn. Gebruikmakend van het verval over de stuw kunnen vrij afstromende geultracés voldoen aan de randvoorwaarden voor ecologisch herstel, zoals voldoende stroomsnelheid, een natuurlijke morfologie en een ongestoorde vegetatieontwikkeling.

In het kader van het programma Ruimte voor de Vecht is het plan opgevat de bestaande stuwpasserende-nevengeul Junne stroomopwaarts te verlengen. Het doel van deze verlenging is het creëren van:

- een 3250 m lange, langzaam stromende beek of rivier op zand (KRW-type R6/ R7), die bovendien vispasseerbaar is;

- nieuw areaal stroomdalgraslanden (N2000-habitattype H6120);

- overstromingsmilieus voor KRW-doelsoorten.

De verlenging van de nevengeul vindt plaats volgens het principe 'Bouwen met Natuur'. Ontwerp en ontwikkeling van de geul na aanleg zijn onderwerp van onderzoek in het Programma Lumbricus Boeiende Beekdalen Proeftuin Oost. Het onderzoek richt zich onder andere op de hydro-morfologische ontwerpeisen, het beheer, welke maatregelen nodig zijn om het morfologische proces op gang brengen en in een dynamisch evenwicht in stand te houden, en hoe de ecologische doelrealisatie in de tijd verloopt.

Voor het ontwerp van de verlengde nevengeul is een landschapsecologische systeemanalyse uitgevoerd (LESA). Het doel van de LESA was antwoord te geven op vijf onderzoeksvragen, die hieronder achtereenvolgens worden behandeld.

\section{Hoe zit het projectgebied fysisch-geografisch in elkaar?}

Het projectgebied ligt in het bereik van een afgesneden verlaten meanderbocht van de Vecht, opgevuld met veen en klei. De binnenzijde van de meanderbocht bestaat uit een kronkelwaard met meanderruggen en -geulen. Een deel van de kronkelwaard is afgegraven en de restgeul gedempt. De drainagebasis in de dalvlakte wordt sterk beïnvloed door het peil van de Vecht. In de laagste delen van de dalvlakte treedt kwel aan maaiveld op.

\section{Verwachte invloed van het substraat op de hydro-morfologische ontwikkeling van de nevengeul}

Het cohesieve karakter van de bodem in de oeverzone van de nevengeul heeft een stabiliserende werking op potentiële morfologische processen in de geul. Laterale verplaatsing van de geul is op grond van de samenstelling van de bodem in de oeverzone en de relatief geringe breedtediepteverhouding niet of nauwelijks te verwachten. Door de samenstelling van het beddingsubstraat en het relatief hoge verhang van de geul is er een risico op verticale erosie.

Het peilverschil tussen de Vecht en de nevengeul bedraagt maximaal ca. 0,80 m. Rivierkwel vanuit de Vecht naar de nevengeul kan lokaal destabiliserend werken op de oevers van de nevengeul.

De aanleg van de nevengeul leidt naar verwachting tot een grondwaterstanddaling.

\section{Welke locatie is - gezien de eisen en randvoorwaarden die eraan worden gesteld - geschikt als moerassige laagte annex vispaaiplaats?}

Het zoekgebied voor een moerassige laagte valt samen met een terreindepressie met grondwatertrap IIa, met een GHG op $5 \mathrm{~cm}-\mathrm{mv}$. en een GLG op $70 \mathrm{~cm}-\mathrm{mv}$. Afgraven van een deel van deze laagte met een wisselende diepte van $20 \mathrm{~cm}$ tot maximaal ca. $50 \mathrm{~cm}$ beneden het huidige maaiveld lijkt een goede uitgangssituatie te geven voor een moeraslaagte waarin het paaien kan plaatsvinden en de larven kunnen opgroeien. 


\section{Wat betekent fysisch-geografische positie voor de realisatiekansen van gewenste natuurtypen?}

De droogste koppen van de kronkelwaard lijken op basis van de GVG geschikt voor de ontwikkeling van stroomdalgrasland (H6120V). De inundatiefrequentie is hier echter te laag. Het meest logisch is dat er in de kronkelwaard allerlei overgangen zullen optreden van stroomdalgrasland naar droog schraalgrasland en heide. Alleen de allerlaagste terreindelen met grondwatertrap wIa en (w)IIa zijn geschikt voor blauwgraslanden (H6410). Voor alle andere delen is een te lage GVG de beperkende factor. De kansen voor 'Vochtige alluviale bossen (beekbegeleidende bossen)' (H91E0C) lijken beperkt tot de restgeul en de laagste delen van de voormalige beddingen.

\section{Hoe worden deze realisatiekansen beïnvloed door de voorgestelde inrichting?}

De grondwaterstanden in het dal zullen als gevolg van het lagere peil in de verlengde nevengeul dalen. Dat betekent een forse verdroging in het noordelijke deel van dit deelgebied. Voor stroomdalgraslanden betekent dat dat deze lager op de gradiënt tot ontwikkeling zullen komen en dat ook de oeverwal ten noordwesten van de inlaat deels geschikt wordt voor dit habitattype. De hoogste kop van de kronkelwaardrug zal hiermee zeker te droog worden en ver buiten het bereik van de verwachte inundaties komen te liggen. Ophoging van de kronkelwaard tot 6,5 m +NAP raden wij af.

Een sterk negatief effect van de grondwaterstanddaling verwachten we voor de realisatiekansen voor blauwgraslanden/overstromingsvegetaties. Stroomafwaarts van het inlaatwerk zal het gebied vrijwel ongeschikt worden voor dit habitattype. Deels kan dit ondervangen worden door in de opgevulde voormalige beddingen (code $\mathrm{H}$ op de kaart met vergaven gronden, zie $\S 2.6$ ) het opgebrachte materiaal te verwijderen. 


\section{$1 \quad$ Inleiding}

\section{$1.1 \quad$ Aanleiding}

Het omvormen van gestuwde en genormaliseerde waterlopen naar vrij afstromende beken of rivieren is in Nederland niet altijd mogelijk in verband met conflicterende belangen en randvoorwaarden. Een goed alternatief voor beek- en rivierherstel in blijvend gestuwde systemen kan de aanleg van stuwpasserende-nevengeulen zijn. Stuw-passerende-nevengeulen zijn te beschouwen als halfnatuurlijke equivalenten van natuurlijke stroomgeulverleggingen (avulsies). Gebruikmakend van het verval over de stuw kunnen vrij afstromende tracés om de stuw worden aangelegd. Hierdoor ontstaat de mogelijkheid te voldoen aan de randvoorwaarden voor ecologisch herstel, zoals voldoende stroomsnelheid, natuurlijke morfologie en een ongestoorde vegetatieontwikkeling. Hoewel er in Nederland enkele van deze stuw-passerende-geulen zijn aangelegd, zijn er nog veel vragen over het ecologisch functioneren van deze geulen, de bijdrage ervan aan het behalen van de KRW-doelen en het ecologisch herstel beekdalbreed (Natura 2000).

Een van de voorbeelden van een stuw-passerende-nevengeul is de nevengeul om stuw Junne in de Overijsselse Vecht. Deze stuw-passerende-nevengeul is aangelegd in 2011-2012 en is $1400 \mathrm{~m}$ lang. Via een cascade is deze geul net bovenstrooms van de stuw aan de Vecht gekoppeld en stroomt ca. $700 \mathrm{~m}$ benedenstrooms van de stuw weer terug in de Vecht. Het verval over de stuw is ca. $2 \mathrm{~m}$. De gronden om de nevengeul zijn in eigendom en beheer van Staatsbosbeheer.

\section{Verlenging nevengeul}

In het kader van het programma Ruimte voor de Vecht is het plan opgevat de bestaande stuwpasserende-nevengeul stroomopwaarts te verlengen (Figuur 1.1). Het project 'Verlenging Nevengeul Junne' combineert verschillende doelen. In de eerste plaats is het een project van waterschap Vechtstromen voor de Kaderrichtlijn Water (KRW) en het Natura 2000-programma. Het gaat hierbij om het realiseren van:

- 1900 m lange, langzaam stromende beek of rivier op zand (KRW-type R6/ R7), die bovendien ook vispasseerbaar is;

- overstromingsmilieus voor KRW-doelsoorten;

- uitbreiding van het areaal stroomdalgraslanden (N2000).

\section{Proeftuin Lumbricus}

Tegelijkertijd is deze geulverlenging een proefproject in het kader van het thema 'Boeiende Beekdalen' van het programma Lumbricus. De proef richt zich op het uitbreiden van de nevengeul volgens het principe 'Bouwen met Natuur'. Onderzoeksvragen in dit proefproject hebben betrekking op de hydromorfologische ontwerpeisen en het beheer waaraan een dergelijke geul moet voldoen. In hoeverre kan een nevengeul zichzelf ontwikkelen, welke maatregelen zijn nodig om dat proces op gang te brengen en hoe verloopt het morfologisch proces en de ecologische doelrealisatie in de tijd? Daarnaast is het noodzakelijk de risico's voor waterveiligheid en gebruik nader te bestuderen (Maas en Van Slobbe, 2017). Meer informatie over het Programma Lumbricus kan verkregen worden via de website van het programma: http://www.programmalumbricus.nl/thema/boeiende-beekdalen/.

In het kader van Lumbricus Boeiende Beekdalen is een beknopte versie van de LESA uitgevoerd, een 'mini-LESA'. Het doel van deze landschapsecologische systeemanalyse is meervoudig. In de eerste plaats geeft de LESA een beeld van het bestaande fysisch-geografische systeem. Dit is van belang voor het ontwerp van de verlengde nevengeul volgens de principes van 'Bouwen met Natuur'. Waar kan de nevengeul landschapsecologisch gezien het beste worden aangelegd, wat zijn de geschikte ontwerpdimensies van de geul en welke hydro-morfologische processen kunnen we verwachten op basis van het bodemmateriaal waarin de geul wordt aangelegd? In de tweede plaats geeft de LESA inzicht in de mogelijke effecten van de aanleg van de geul op het systeem. Zijn er bijvoorbeeld effecten te verwachten op het grondwaterregiem door de aanleg van de geul? En ten slotte geeft de 


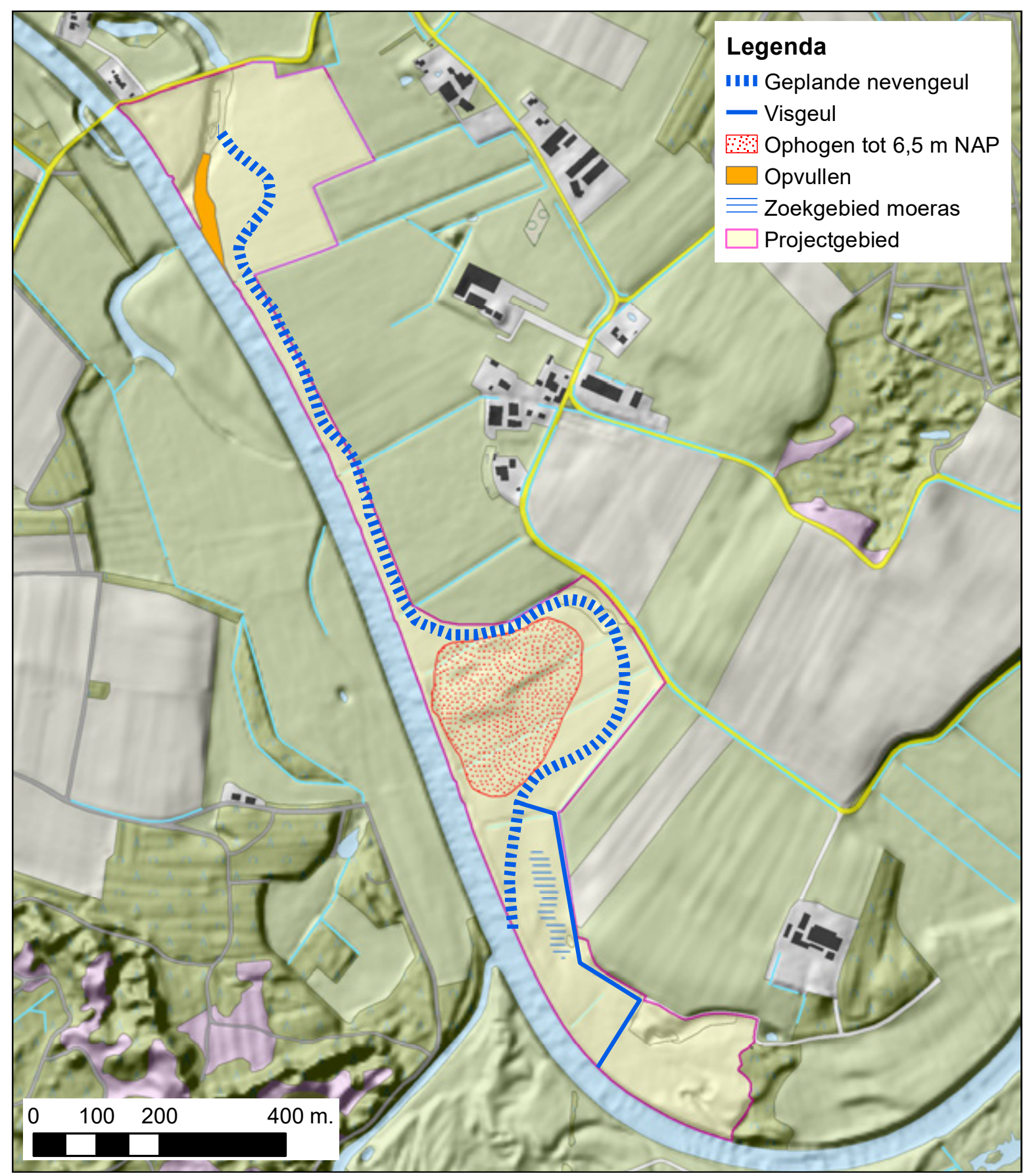

Figuur 1.1 Begrenzing projectgebied en maatregelen op hoofdlijnen (zie ook WENR, 2017; Arcadis 2017).

Uitgangspunt voor deze analyse is het plan zoals dat is uitgewerkt in de tekening van 15 september 2017 (Maas et al., 2018; Arcadis 2017) en de begrenzing van het projectgebied voor de verlengde nevengeul. Dit plan is tot stand gekomen in een ontwerpsessie met vertegenwoordigers van waterschap Vechtromen en het Programma Lumbricus Boeiende Bekdalen (Maas et al., 2018). De hydraulische eisen voor de nevengeul zijn vastgelegd in een memo (Van der Scheer, 2017). Het projectgebied van de bestaande nevengeul is buiten beschouwing gelaten. In Figuur 1.1 zijn de belangrijkste inrichtingsmaatregelen schematisch aangegeven. In het definitieve ontwerp zijn deze nader uitgewerkt. Relevant voor dit onderzoek zijn de volgende inrichtingsmaatregelen:

- Het aanleggen van een verlengde nevengeul, deels door het tracé van een vroegere meander; 
- Het aanleggen van een moeraslaagte, deels als paaiplaats voor vis;

- Het graven van een vismigratiegeul, aansluitend op deze laagte;

- Het deels ophogen van een voormalige kronkelwaard ten behoeve van stroomdalgraslanden;

- Het dempen van de instroomopening van de bestaande nevengeul bij de stuw van Junne.

In het ontwerpproces bouwen met natuur zijn drie deelgebieden (Figuur 1.2) onderscheiden:

a. Inlaat nevengeul vanuit de Vecht; voormalige meanderbocht met veel ruimte voor procesnatuur; integrale ontwerp opgave voor stroomdalgraslanden (H6120), langzaam stromende (en in een dynamisch evenwicht verkerende) beek op zand (R6/7) en overstromingsgrasland;

b. Smalle, ca. $35 \mathrm{~m}$ brede zone parallel aan de Vecht; beperkte ruimte voor procesnatuur i.v.m. risico op oeverinstabiliteit; ontwerp opgave: stabiele langzaam stromende beek op zand (R6/7);

c. Uitstroom in bestaande nevengeul met matig veel ruimte voor procesnatuur; ontwerp opgave: langzaam stromende beek op zand (R6/7) in een dynamisch evenwicht.

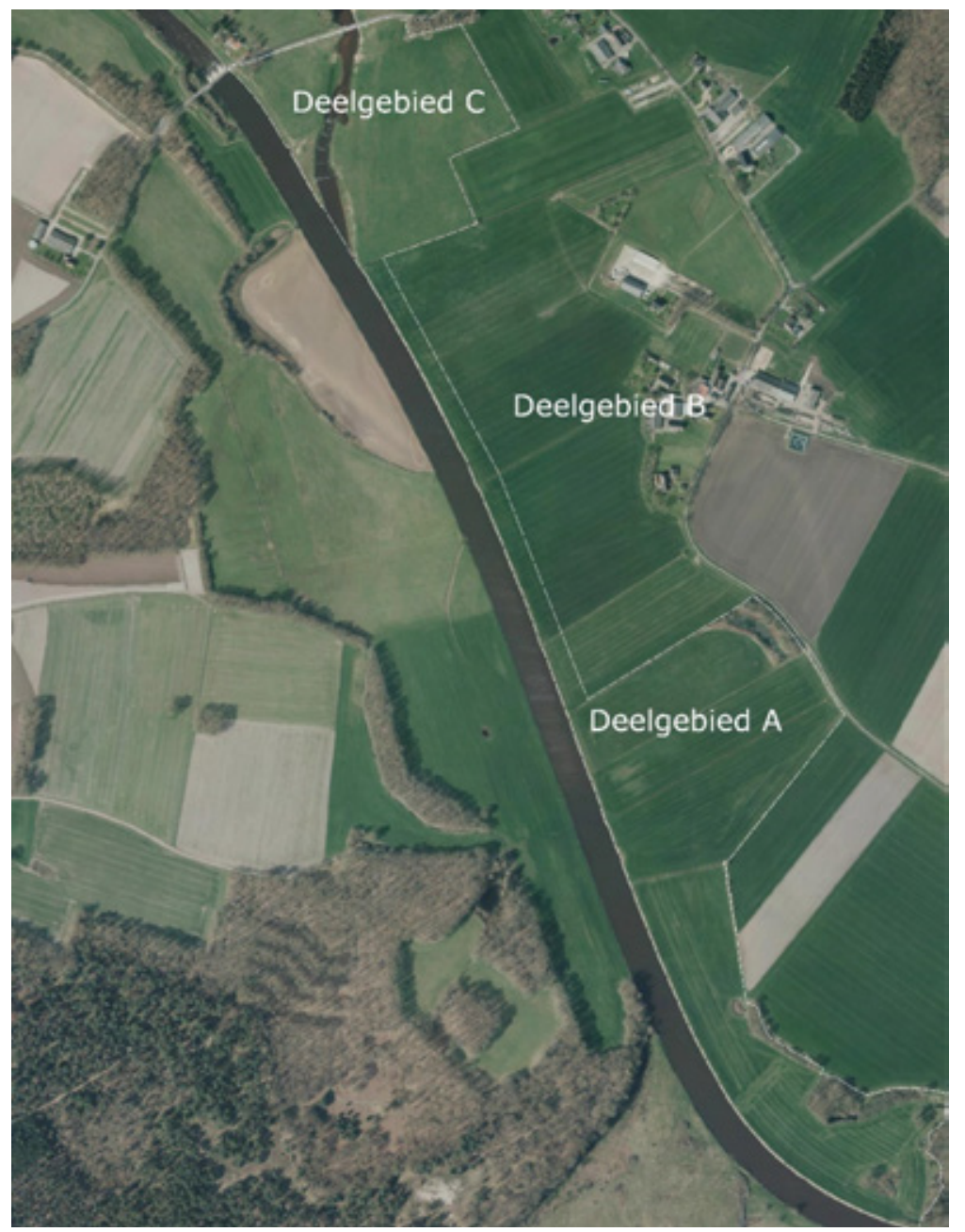

Figuur 1.2 Deelgebieden.

\subsection{Onderzoeksvragen}

\section{Hoe zit het projectgebied fysisch-geografisch in elkaar?}

De geomorfologische/bodemkundige gesteldheid in combinatie met de hydrologische positie is bepalend voor het landschapsecologisch functioneren van het projectgebied.

\section{Wat is het substraat waar de verlengde nevengeul doorheen gaat stromen?}

Dit is relevant om een inschatting te kunnen maken van de mate waarin natuurlijke morfologische processen gaan plaatsvinden, gegeven het debiet en verhang in de nevengeul. Maar ook voor een 
inschatting van risico's op ongewenste neveneffecten, zoals oeverinstabiliteit van de geul in het tracé van de nevengeul parallel aan de Vecht, of effecten op de grondwaterstand.

3. Welke locatie is - gezien de eisen en randvoorwaarden die eraan worden gesteld geschikt als moerassige laagte annex vispaaiplaats?

Voor de vissoorten zoals de kwabaal gelden behoud of uitbreidingsdoelen, waaraan de moerassige laagte en de vismigratiegeul een bijdrage moeten leveren. Voor het optimaal functioneren moeten deze een bepaalde diepte hebben en worden eisen gesteld aan overstromingsfrequentie en waterkwaliteit.

4. Wat betekent de fysisch-geografische positie voor de realisatiekansen van gewenste natuurtypen?

Het zuidelijke deel, waarin ook het zoekgebied voor de moerassige laagte ligt, valt binnen N2000 gebied Vecht en Beneden Regge (Vechtstromen 2016; Jalink et al., 2017). Voor de volgende terrestrische Habitattypen en enkele aanvullende vegetatietypen zijn de realisatiekansen beoordeeld:

- H6120 - 'Stroomdalgraslanden' op zandige oeverwallen en kronkelwaarden

- H6410 - 'Blauwgrasland' in de delen met vochtig grasland

- H7140 - 'Overgangs- en trilvenen' in oude meanders

- H91E0C - 'Bossen op alluviale grond met Alnus glutinosa en Fraxinus excelsior'

- H4010A - 'Vochtige heiden (hogere zandgronden)' op de drogere dalflanken

5. Hoe worden deze realisatiekansen beïnvloed door de voorgestelde inrichting?

De voorgestelde inrichting en andere maatregelen die samenhangen met 'Ruimte voor de Vecht', zoals aanpassingen in het peilbeheer, zijn van invloed op de realisatiekansen voor natuurtypen.

\subsection{Werkwijze}

De landschapsecologische systeemanalyse die in dit project is uitgevoerd, is een beknopte versie (mini-LESA) van de analyse zoals beschreven in de Landschapsleutel (Kemmers et al., 2011; Van Delft et al., 2015) en omvat de volgende onderdelen:

1. Bureauanalyse van de geologische en geomorfologische uitgangssituatie van het studiegebied.

2. Analyse van de landschapsontwikkeling van het studiegebied vanaf 1754 .

3. Een gedetailleerde bodemkartering met beschrijving van bodemprofielen, humusprofielen en $\mathrm{pH}-$ profielen tot een diepte van maximaal 2,5 m-mv. Voor een beschrijving van de opnamemethode en de locatie van de boorpunten zie Bijlage 2.

4. Meting van grondwaterstanden en elektrisch geleidingsvermogen (EGV) in een aantal boorgaten.

5. Uitwerking profielen in twee lengteprofielen langs het tracé van de verlengde nevengeul en één dwarsprofiel van de Vecht naar de hogere gronden buiten het winterbed:

- Inzicht in het substraat waar de verlengde nevengeul doorheen stroomt;

- Indicatie van grondwaterstandverloop en drainerende werking Vecht en verlengde nevengeul.

6. Interpretatie van de gegevens op basis van landschapsecologische indeling van de

Landschapsleutel (Kemmers et al., 2011; Van Delft et al., 2015) in:

- Landschappelijke bodemkaart;

- Realisatiekansen habitattypen huidige situatie, inclusief knelpuntenanalyse;

- Inschatting benodigde dieptes voor moeraszone en vismigratiegeul;

- Inschatting effect maatregelen op realisatiekansen habitattypen en knelpunten.

Het veldwerk is uitgevoerd in september 2017. 


\section{$1.4 \quad$ Resultaat}

Het resultaat van deze LESA is:

1. Een set kaarten en dwarsprofielen die betrekking hebben op de verschillende fysisch-geografische kenmerken van het studiegebied. Elk kenmerk is voorzien van een korte toelichting. De volgende aspecten komen achtereenvolgens aan de orde:

- Geologische en geomorfologische uitgangssituatie

- Landschapsontwikkeling vanaf 1754

- Bodemkaart

- Textuur ondergrond

- Bodemverwerking en maaiveldverlaging

- Grondwaterstandverloop en inundatiekarakteristiek

- EGV en pH van het oppervlakte- en grondwater

2. Beschrijving en analyse van het substraat en de grondwatersituatie in het lengteprofiel van de ontwerp-nevengeul en een beschrijving en analyse van het dwarsprofiel door de nevengeul en het aangrenzende stroomdalgrasland.

3. Realisatiekans voor de Natura 2000-habitattypen:

- Fysisch-geografische positie

- Potentiële vegetatieontwikkeling

- Advies moerassige laagte

- Realisatiekansen en knelpunten huidige situatie

- Effect inrichting op realisatiekansen en inrichting 


\section{Geologie, landschap en bodem}

\section{$2.1 \quad$ Geologie}

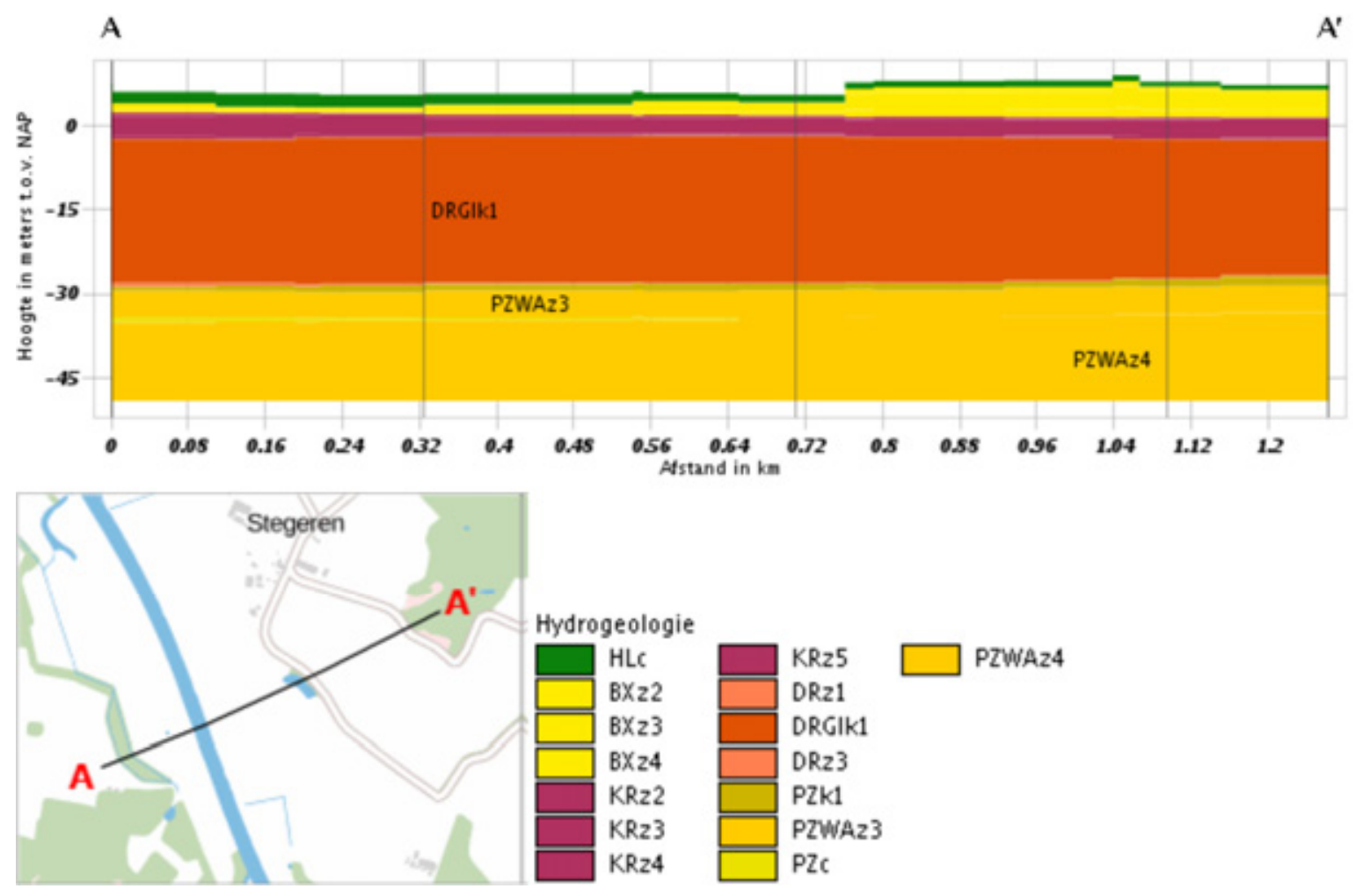

Figuur 2.1 Hydro-geologische doorsnede dwars op het Vechtdal. PZWAz = Formatie van Peize en Waalre (overwegend grof zand); DRGik = Formatie van Drenthe, laagpakket van Gieten (keileem); $K R z=$ formatie van Kreftenheye (overwegend grof zand, kalkloos tot kalkrijk); BXz = formatie van Boxtel (zand, fijn en grof, leemarm tot sterk lemig en leem; HLc = holocene afzettingen van de vecht (zand en klei). Bron: www.dinoket.nl (REGIS II v2.2).

In Figuur 2.1 is een geologische dwarsdoorsnede opgenomen van de bovenste $50 \mathrm{~m}$ onder het Vechtdal ter hoogte van de oude Vechtarm. Volgens dit model bestaat de bovenste $4 \mathrm{~m}$ voornamelijk uit afzettingen die tot de Formatie van Boxtel gerekend worden en een laag holocene afzettingen van de Vecht. Vanaf ca. $2 \mathrm{~m}$ +NAP begint de Formatie van Kreftenheye met grove en deels kalkrijke rivierzanden. Bij boringen van RHDHV in de omgeving van de Karshoek werden deze afzettingen ondiep aangetroffen en zijn in een aantal gevallen ook schelpresten waargenomen, hetgeen een aanwijzing is dat een deel van deze afzettingen ook kalkhoudend is (Jalink \& Van Delft, 2017). De basis van het bovenste watervoerend pakket wordt hier gevormd door de keileem (Formatie van Drenthe), die rond -2 m NAP begint en hier ca. $15 \mathrm{~m}$ dik is. Naar verwachting zullen grondwaterstromen door de formaties van Boxtel en Kreftenheye plaatsvinden, met lokale stromingen over leemlagen binnen de Formaties van Kreftenheye en Boxtel.

\subsection{Geomorfologische kaart 1890}

De geomorfologie van het Vechtdal wordt sterk bepaald door het dynamische karakter dat de rivier in het verleden heeft gekend, deels onder invloed van menselijk handelen. Zo lijkt de sterke meandering deels samen te hangen met de zandverstuivingen die veelvuldig voorkwamen langs de Vecht en toegeschreven moeten worden aan het intensieve gebruik van de woeste gronden. Deze processen 
worden elders uitvoerig besproken (o.a. Wolfert et al., 1996, 2009; Wolfert, 2001; Quick, 2016). Hier wordt alleen ingegaan op de invloed op de geomorfologie en bodem in relatie tot het functioneren van het projectgebied en directe omgeving.

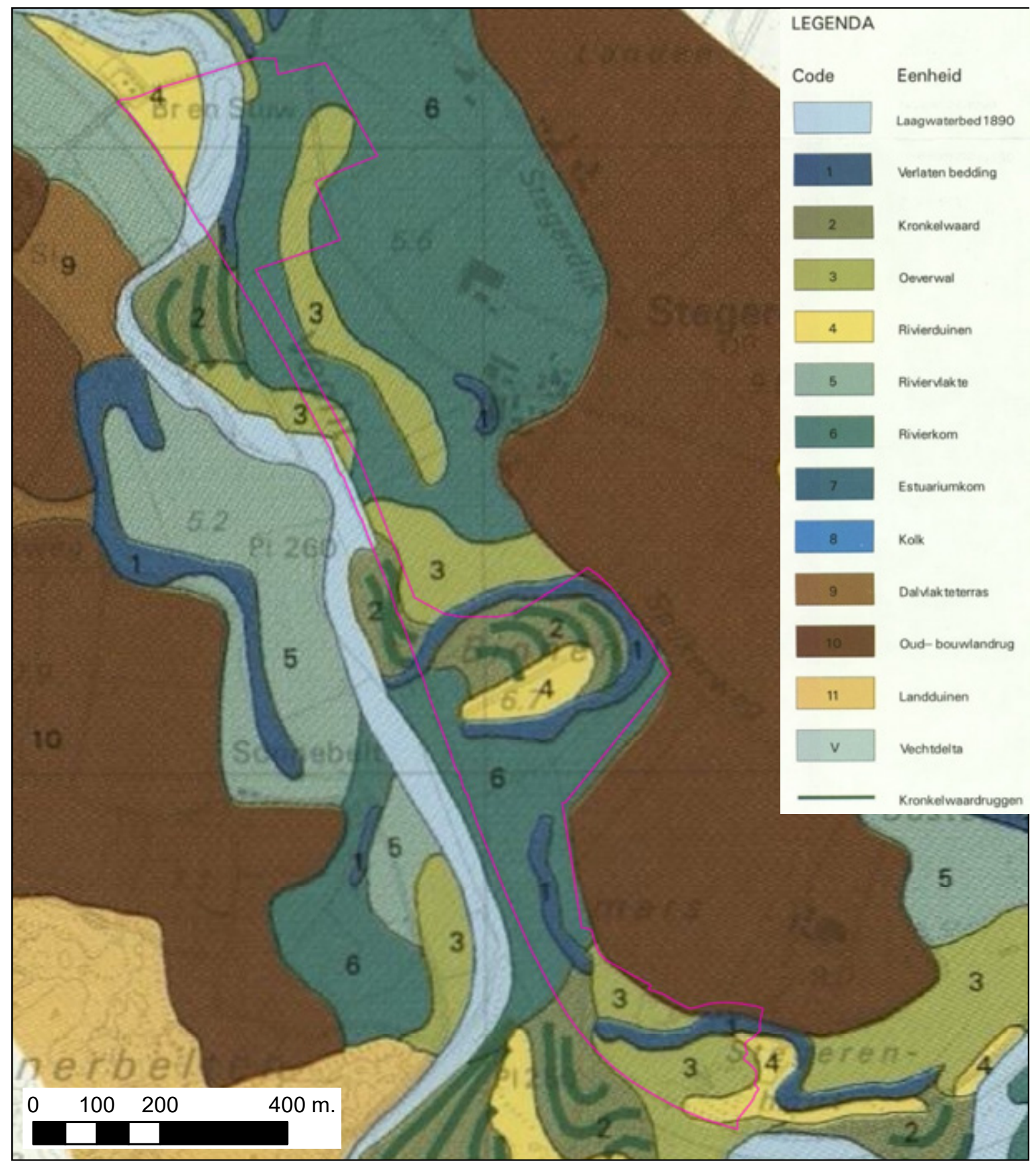

Figuur 2.2 Geomorfologische gesteldheid van de Overijsselse vecht rond 1890 (Wolfert et al., 1996). De eenheden 7, 8 en $V$ komen in deze uitsnede niet voor.

De situatie aan het einde van de dynamische periode (ca. 1890) wordt goed beschreven in Figuur 2.2. Behalve in het noorden, waar de bestaande nevengeul begint, stroomt de Vecht niet meer door het projectgebied. Verspreid zijn nog wel verlaten beddingen te herkennen, waarvan nu nog restanten voorkomen in het zuidoosten en ten noordoosten van de kronkelwaard bij de Spijkerweg, in beide gevallen tegen de hogere gronden aan. Binnen de grote, hoefijzervormige verlaten bedding is een kronkelwaard tot ontwikkeling gekomen die ook nu nog deels gaaf en goed herkenbaar is, alleen het tot rivierduin verstoven deel is later door afgraving verdwenen. In het meest zuidwestelijke deel en verspreid in de noordelijke helft van het projectgebied komen oeverwallen voor en kleine stukken van kronkelwaarden. Het centrale deel, ten zuiden van de kronkelwaard, bestaat uit een rivierkom. 


\subsection{Landschapsontwikkeling sinds 1754}

In Bijlage 1 is de landschappelijke ontwikkeling in het projectgebied weergegeven op basis van kaartfragmenten van topografische kaarten (bronnen: Provincie Overijssel http://gisopenbaar.overijssel.nl/viewer/app/atlasvanoverijssel_basis/v1 en Topotijdreis http://www.topotijdreis. $\mathrm{nl} /$ ). Twee van deze kaarten die de ontwikkeling in de laatste eeuw goed illustreren, zijn opgenomen in Figuur 2.3.
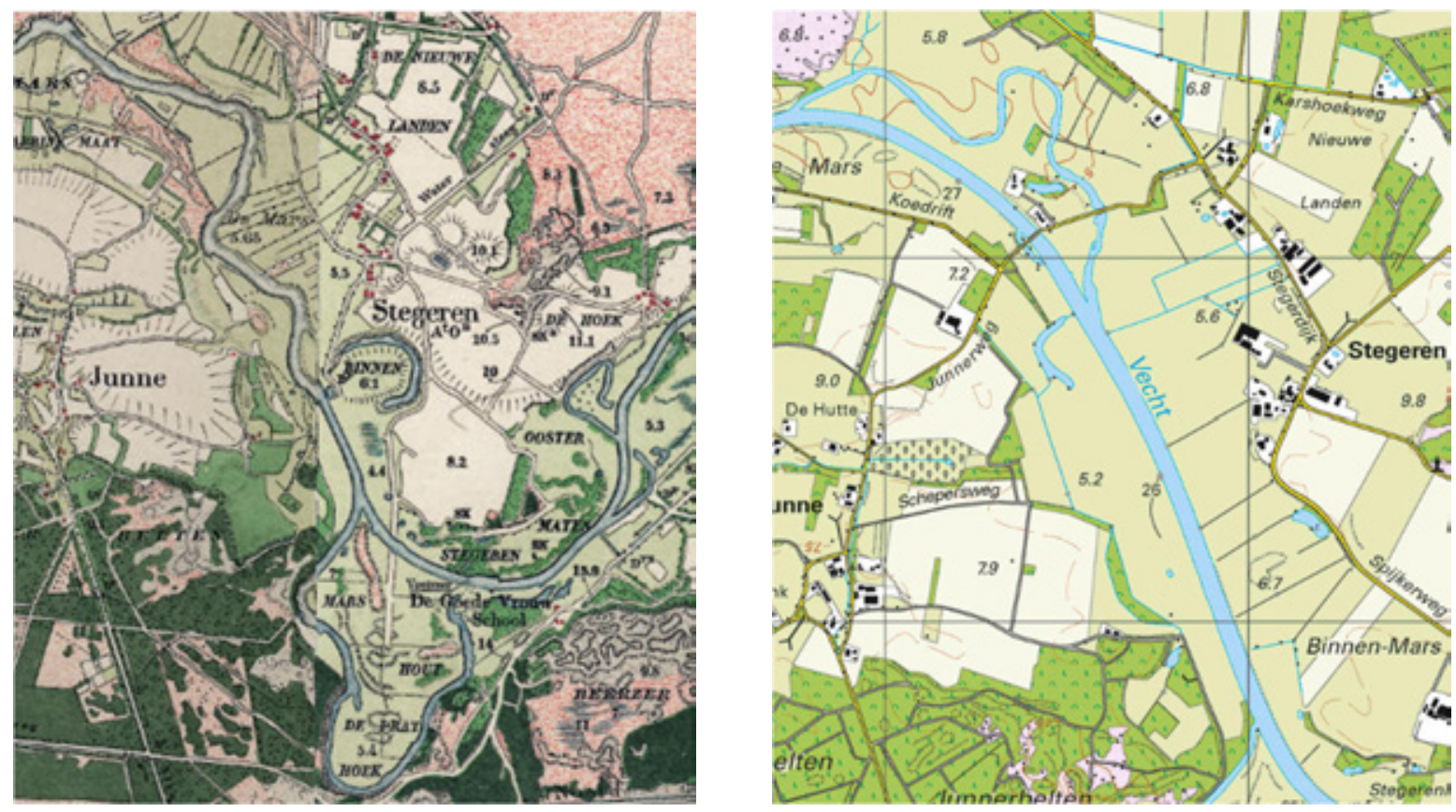

Figuur 2.3 Topografische kaarten van het projectgebied en omgeving uit 1904 en 2014 .

Op de oudste kaart (Hattinga, 1754) is te zien dat de bedding langs de Spijkerweg al verlaten was, er is stroomafwaarts nog wel een verbinding met de Vecht. Onduidelijk is of dit een natuurlijke afsnijding was of dat deze is doorgegraven. Het hele tracé van de Prathoek tot bij Junne is vrij recht ingetekend. De Vecht wordt geflankeerd door verspreid bos en grasland, met op de hogere gronden bouwland en heide. In 1787 is op de kaart van Hottinger de bocht aan de westkant, bij De Mars, zichtbaar; mogelijk is het ontbreken ervan op de vorige kaart een onzuiverheid in de kaart. Deze situatie blijft grotendeels onveranderd tot op de Bonne-kaart van 1904, waar de meander van de Prathoek is afgesneden. Omdat kaarten altijd achterlopen bij de werkelijkheid, moet dat ergens in de jaren daarvoor gebeurd zijn. Vanuit het dorpje Stegeren loopt een weg als ontsluiting van de kronkelwaard. Ten noorden hiervan, bij De Mars, is in de graslanden een slagenverkaveling te zien, wat wijst op gebruik als hooiland; in de kronkelwaard en ten zuiden ervan (inclusief Prathoek) komen weidegronden met verspreid bos voor. In 1908 is ook de meander bij De Mars afgesneden, de doorsteek bij Junne staat al wel als gepland ingetekend. Langs de oostzijde van de meander is een weg aangelegd naar het pontje waarmee de afgesneden Prathoek bereikbaar is. Op de kaart van 1931 is ook de meander bij Junne afgesneden en de stuw bij Junne aangelegd. De meander aan de Spijkerweg is in 1936 gedeeltelijk verland of gedempt, maar nog wel als natte laagte aangegeven. De slagenverkaveling bij De Mars is niet meer aangegeven; in plaats daarvan is reliëf ingetekend, wat verband houdt met de oeverwallen die hier gelegen hebben. In 1954 is de meander aan de Spijkerweg teruggebracht tot zijn huidige omvang; er is nog wel een afwatering te zien door een duiker naar de Vecht. Op deze kaart is ook voor het eerst een lage kade aangegeven langs de Vecht. In die tijd loopt de Spijkerweg vanaf het begin van de meander over de es naar het noorden. Deze weg is waarschijnlijk tijdens de ruilverkaveling langs de rand van het Vechtdal verlegd, zoals op de kaart van 1975 te zien is. De resten van de oude patronen zijn dan ook grotendeels verdwenen en het rivierduin in de meander is afgegraven. Het perceel waarin dit duin lag, is toen grotendeels geëgaliseerd. Het deel met de kronkelwaard is aangegeven als bouwland. In 2013 zijn de sporen van de oude Vechtlopen grotendeels verdwenen, terwijl in 2014 de bypass bij Junne is gegraven. 


\section{$2.4 \quad$ Bodemkaart}

De resultaten van de bodemkartering zijn opgenomen in Figuur 2.5, 2.7, 2.9, 2.11, 2.15 en 2.17. De kaarten zijn gebaseerd op de profielbeschrijvingen waarbij het hoogtebestand (AHN), de veldwaarnemingen en de in paragraaf $2.1 \mathrm{t} / \mathrm{m} 2.3$ besproken informatie zijn gebruikt om kaartvlakken af te grenzen. Voor beschrijving van de legendaeenheden wordt verwezen naar bodemkundige handboeken (De Bakker \& Schelling, 1989; Booij, 1989; Brouwer et al., 1992; Ten Cate et al., 1005).

Het grootste deel van het projectgebied bestaat uit bruine beekeerdgronden (tbZg53 en tbZg55), in de lagere delen komt hier vaak ook een kleidek ( $<40 \mathrm{~cm}$, toevoeging k..., Figuur 2.4 links) voor. In een strook langs de huidige Vecht in het zuidelijke deel is het kleidek dikker dan $40 \mathrm{~cm}$ en komen leekeerdgronden voor (tRn25C) met meer dan $80 \mathrm{~cm}$ klei en een minerale eerdlaag (Figuur 2.4 midden). In een verlande restgeul is het kleipakket $40-80 \mathrm{~cm}$ dik en ontbreekt de minerale eerdlaag. Dit is een poldervaaggrond (Rn22C). De kleidekken en kleigronden bestaan uit zavel. In het centrale deel met de meander en de lagere delen ten zuiden daarvan komen zowel in de beekeerdgronden als de kleigronden ijzerrijke (roodoornige) bovengronden voor (toevoeging f...). Dat geldt ook voor een oeverwal in de afgesneden meander van De Mars, waar ook dieper zeer harde roodoornige kleilagen voorkomen.

Wat hoger op de gradiënt zijn gooreerdgronden onderscheiden (tZn53) waarin behalve een dunne minerale eerdlaag geen bodemvorming is te onderscheiden. Voor een deel betreft dit gronden op de overgang van hogere infiltratiegronden buiten het Vechtdal en de beekeerdgronden in het Vechtdal waar door kwelinvloed ijzer en andere mineralen in de bovengrond zijn afgezet.
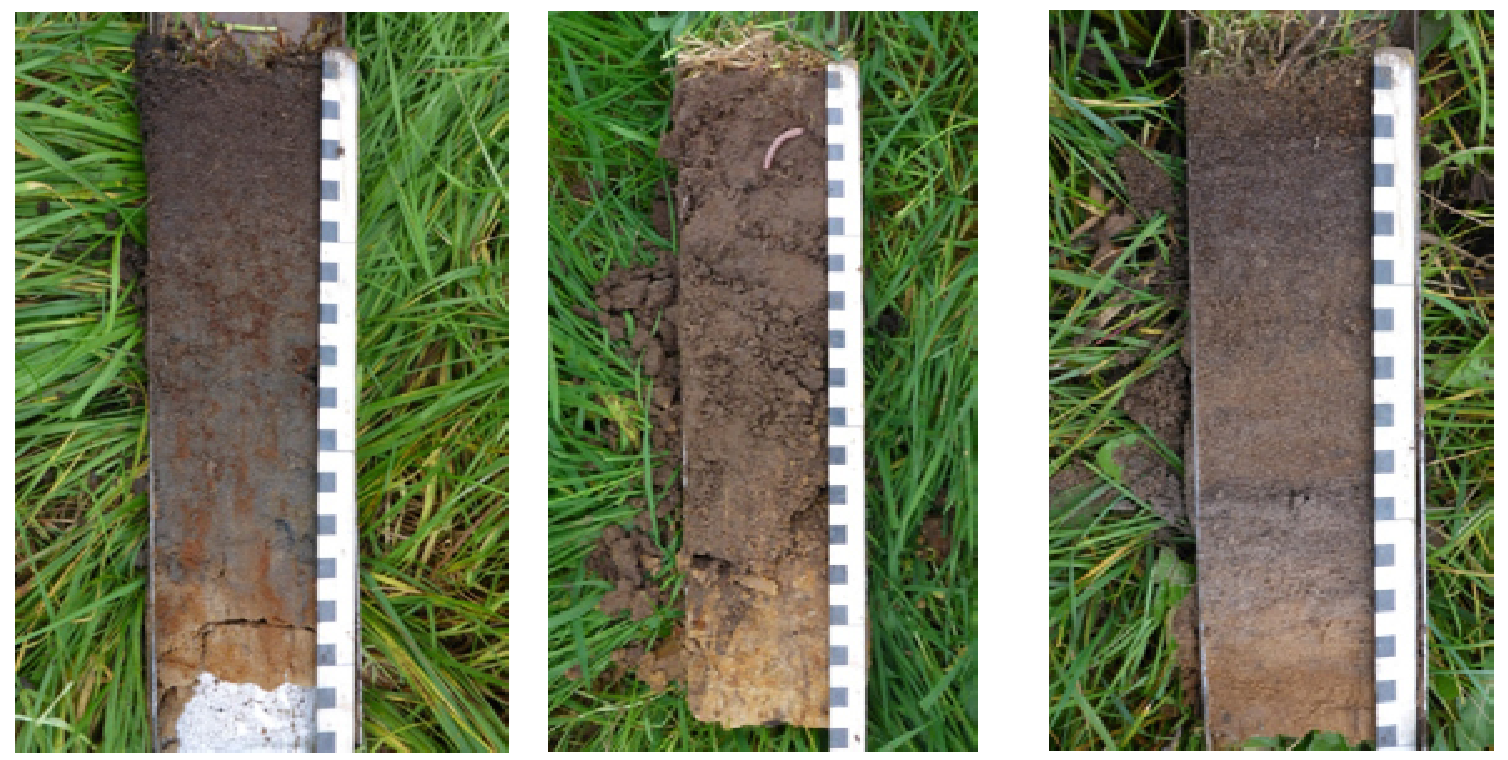

Figuur 2.4 Bovengronden van resp. van links naar rechts een beekeerdgrond met kleidek en ijzerrijke bovengrond (fktZg55, boring 2003), een leekeerdgrond (tRn25C, boring 2030) en een vorstvaaggrond (Zb53, boring 2005).

Op de hoogste zandige koppen in voormalige kronkelwaarden en oeverwallen worden vorstvaaggronden (Zb53, Figuur 2.4 rechts) aangetroffen. Omdat deze opgebouwd zijn uit rivierzand, is de bodem mineralogisch iets minder arm dan de duinvaaggronden in de stuifzandgebieden zoals die buiten het Vechtdal voorkomen. Hoewel uitloging op de hogere delen een natuurlijk proces is, wordt de zuurbuffer in deze gronden bij incidentele overstroming wel weer aangevuld. Langs de oude Vechtloop bij de Spijkerweg komen slappe, venige gronden voor die zijn aangeduid als Plaseerdgrond (Wo, fig. 2.10). 


\section{Legenda}

IIII Geplande nevengeul

Hade

\section{Bodemtypen}

Moerige gronden

Toevoegingen bovengrond

- " IJzerrijke bovengrond

Kleidek

\section{Kalkloze zandgronden}

tbZg53 Bruine beekeerdgrond zwak lemig matig fijn zand tbZg55 Bruine beekeerdgrond sterk lemig matig fijn zand tZn53 Gooreerdgrond zwak lemig matig fijn zand Zb53 Vorstvaaggrond zwak lemig matig fijn zand

\section{Rivierkleigronden}

Rn22C Poldervaaggrond kalkarme zavel op zand $<80 \mathrm{~cm}$ tRn25C Leekeerdgrond kalkarme zavel

\section{Overige onderscheidingen}

Water

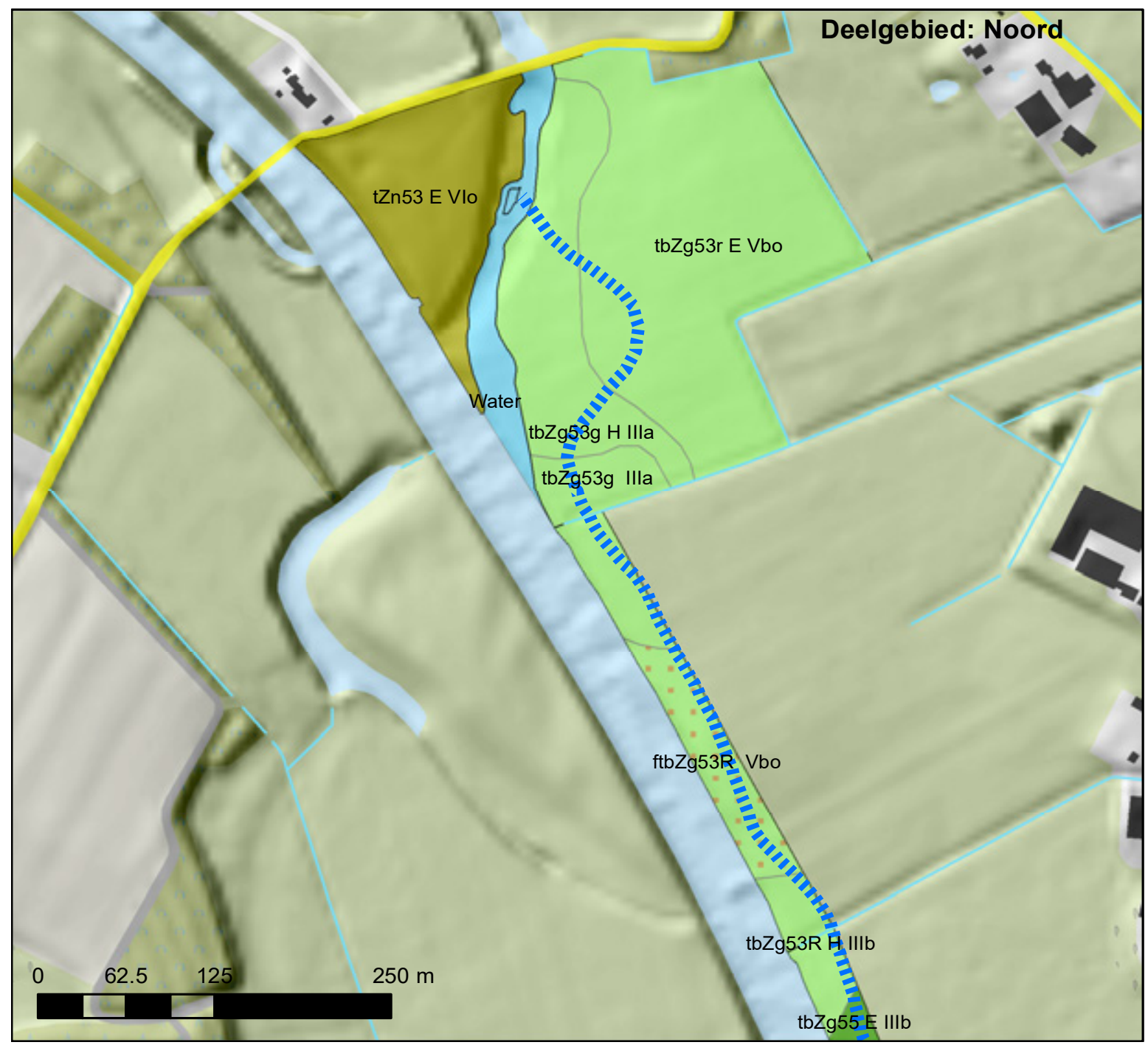

Figuur 2.5a Bodemkaart. 


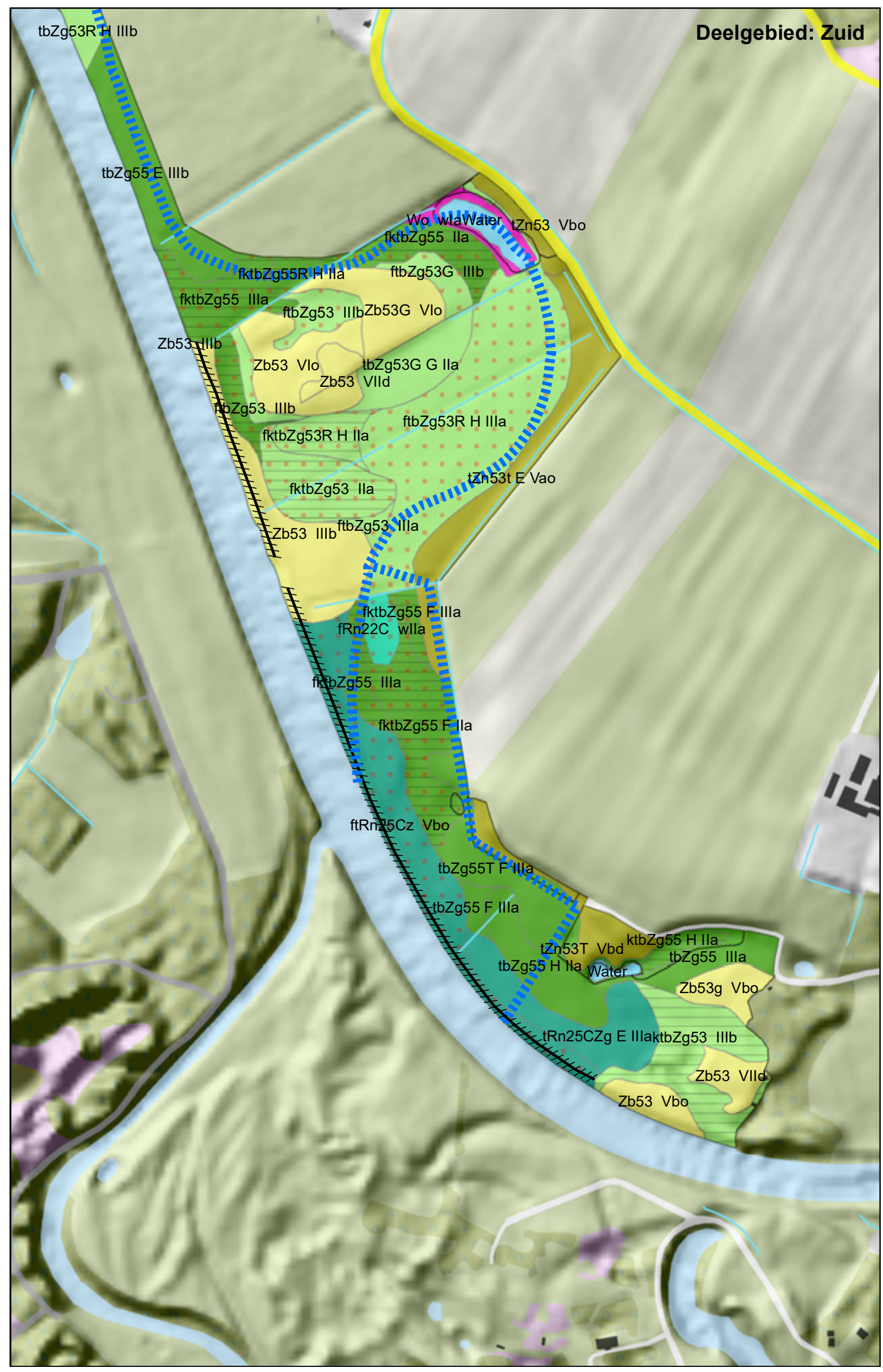

Figuur 2.5b Bodemkaart. 


\subsection{Ondergrond}

De bodemkaart zoals hiervoor besproken, levert belangrijke informatie over het bovenste deel van de bodem en is ook relevant als groeiplaats voor de natuurlijke vegetatie. Als gevolg van de complexe processen van de vorming en opvulling van het Vechtdal, is de samenstelling van de ondergrond zeer divers. Deze is van groot belang voor de drainerende werking onder natte omstandigheden en capillaire opstijging bij droogte. Daarnaast worden de morfologische processen in de verlengde nevengeul medebepaald door de samenstelling van het substraat waar deze doorheen stroomt. Tot slot is dit van belang voor de macrofauna in de nevengeul. In Figuur 2.7 is de variatie in de ondergrond weergegeven. Op diverse plaatsen is door de Vecht grof zand afgezet (toevoeging ...G of ...g). Bij de verlanding van oude stroomgeulen is een pakket slappe klei afgezet, vaak met veenlaagjes (toevoeging ...R of ...r). Dit materiaal wordt ook wel aangetroffen waar oude geulen gedempt zijn, maar is dan vaak wel gerijpt en dus steviger. Onder de zavelgronden (tRn25) in het zuidelijke deel komen zandige Vechtafzettingen voor (toevoeging ...Z en ...z). Op de oostelijke flank van het Vechtdal komen ondiep ook pleistocene afzettingen voor met leemlagen (toevoeging ...T of ...t).

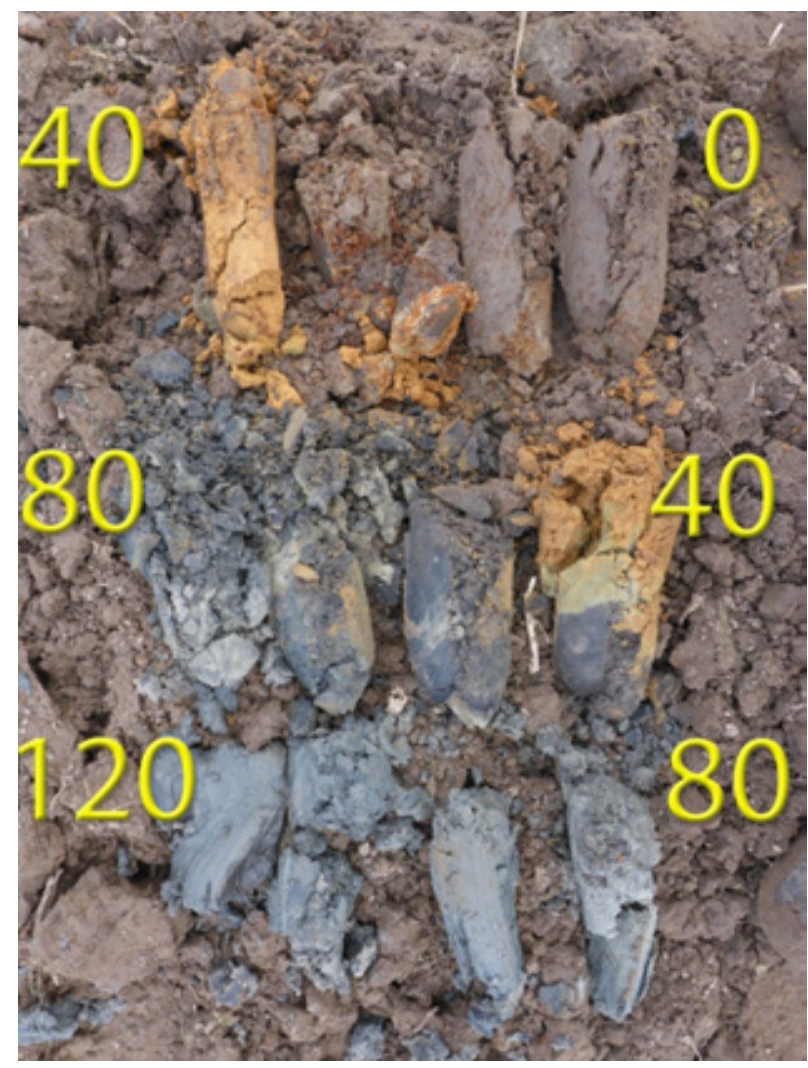

Figuur 2.6 Beddingopvulling van deels ongerijpte klei en veen in boring 2010.

De in $\S 2.3$ beschreven ontwikkelingen komen tot uiting in de kaart van verwerkte gronden (Figuur 2.9). De opgevulde laagtes en geulen die als zodanig geïdentificeerd konden worden, zijn aangeduid als 'Opgehoogd' $(H)$, het afgegraven rivierduin als 'Afgegraven' $(G)$ en de delen die duidelijk geëgaliseerd zijn als 'Geëgaliseerd' (E). In het perceel ten zuiden van de meander zijn gronden aangemerkt als 'Vergraven' (F), omdat het reliëf hier nog wel min of meer in stand is, maar het profiel wel duidelijke kenmerken van grondbewerking vertoont. 


\section{Legenda}

IIII Geplande nevengeul

\section{Begindiepte Grof zand}

Kade

Begindiepte (meestal niet gerijpte) klei en veen

$R 40-120 \mathrm{~cm}$ $r>120 \mathrm{~cm}$

\section{Begindiepte Fijn zand onder klei}

$\mathrm{Zg} 40-120 \mathrm{~cm}$ op grof zand $z>120 \mathrm{~cm}$
I. G $40-120 \mathrm{~cm}$

- $g>120 \mathrm{~cm}$

\section{Begindiepte Leem}
T $40-120 \mathrm{~cm}$
$\mathrm{t}>120 \mathrm{~cm}$
Bodemkaart vlakken

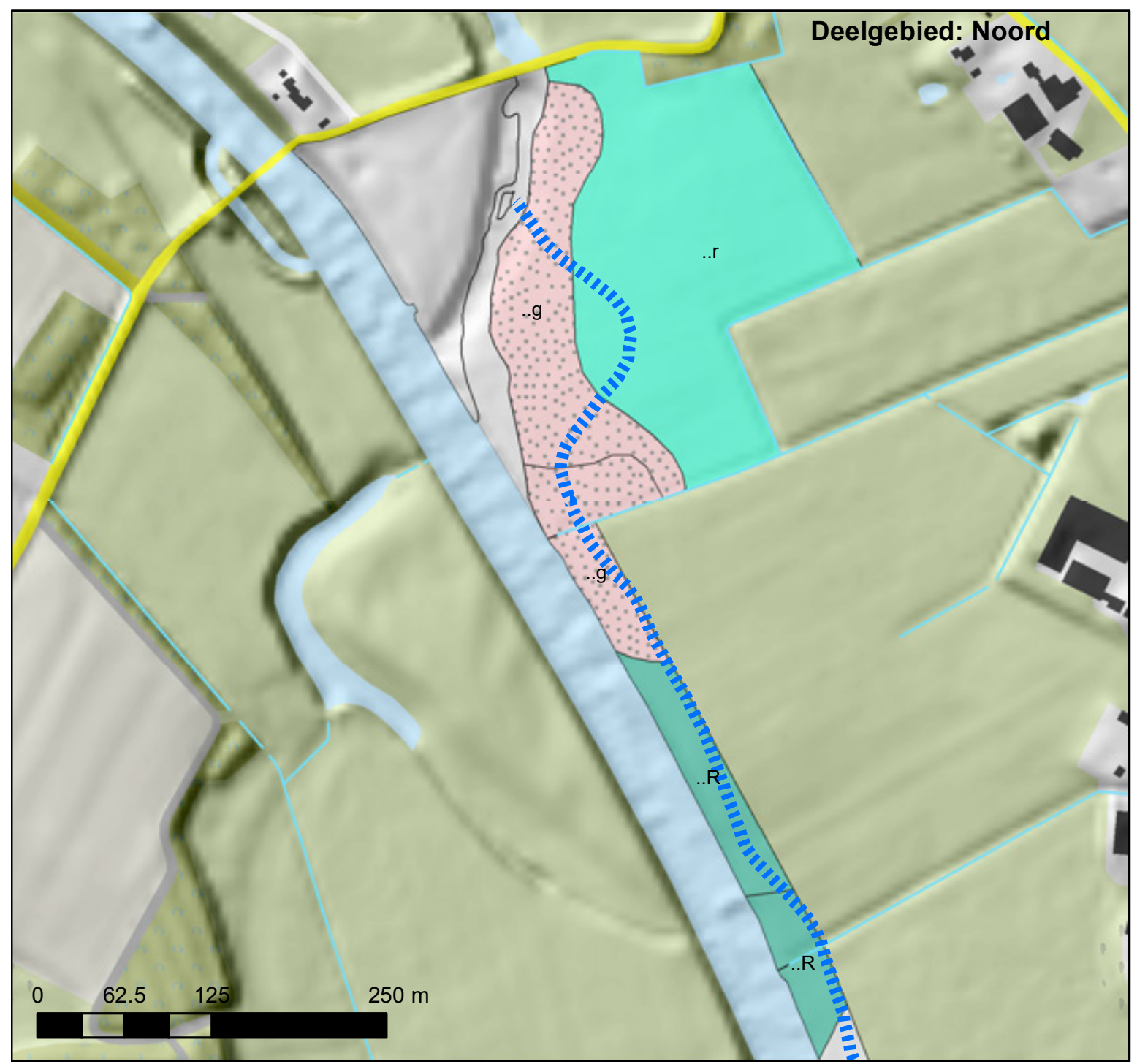

Figuur 2.7 Bodemkaart toevoegingen ondergrond. 


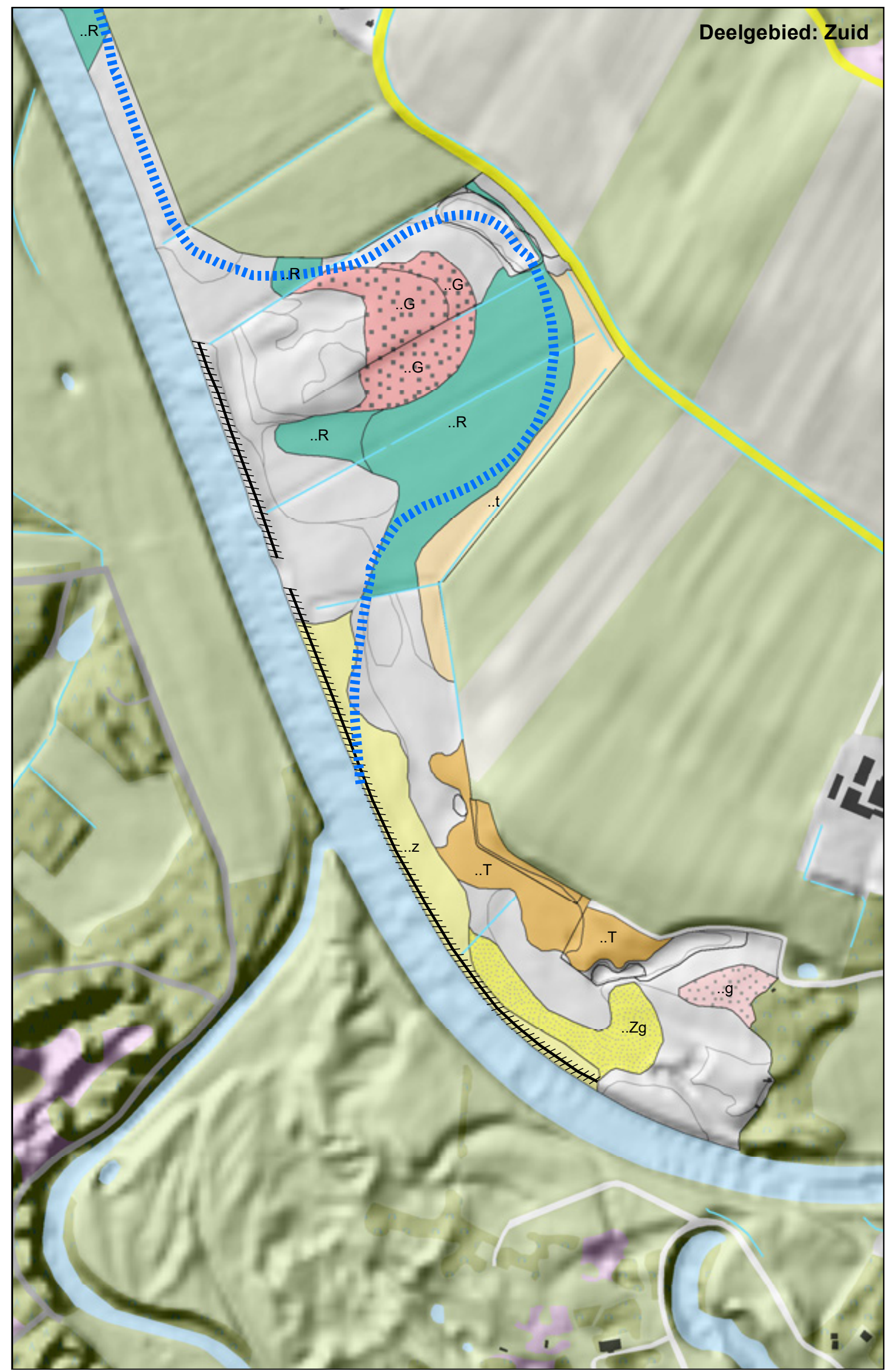

Figuur 2.7b Bodemkaart toevoegingen ondergrond. 


\subsection{Verwerkte gronden}

In Figuur 2.8 is het verschil in maaiveldhoogte bepaald tussen 1960 en 2013. De metingen uit 1960 zijn gebaseerd op de hoogtepuntenkaart 1 : 10.000 van de Meetkundige dienst en zijn vóór de ruilverkaveling opgemeten. Deze punten zijn vergeleken met het AHN2 uit 2013. Ondanks onzekerheden door meetfouten geeft de kaart een beeld van de veranderingen die in het kader van de ruilverkaveling - en mogelijk ook daarna - hebben plaatsgevonden. In Figuur 2.9 zijn de bodembewerkingen weergegeven. Ter plaatse van het voormalige rivierduin in de meander is tot $1 \mathrm{~m}$ afgegraven en ook de oeverwal in het zuidoosten is lokaal fors verlaagd (G). Sterke ophogingen worden gevonden in een strook ten noorden en oosten van de kronkelwaard $(H)$, wat een aanwijzing kan zijn dat restanten van de oude bedding in 1960 nog wel als een laagte herkenbaar waren. Verder komen minder sterke afgravingen en ophogingen naast elkaar voor, wat wijst op egalisatie van de percelen (E \& F)). De gevonden verschillen lijken aan te geven dat weliswaar een deel van de oude patronen vóór 1960 is verdwenen door verlanding, demping en egalisatie, maar dat de grootste ingrepen waarschijnlijk tijdens de ruilverkaveling en de periode daarna hebben plaatsgevonden. In het noorden, bij de huidige bypass, is het hoogtebeeld van AHN2 ook niet meer actueel, omdat hier nog de oude meander zichtbaar is en de bypass een iets ander verloop heeft.

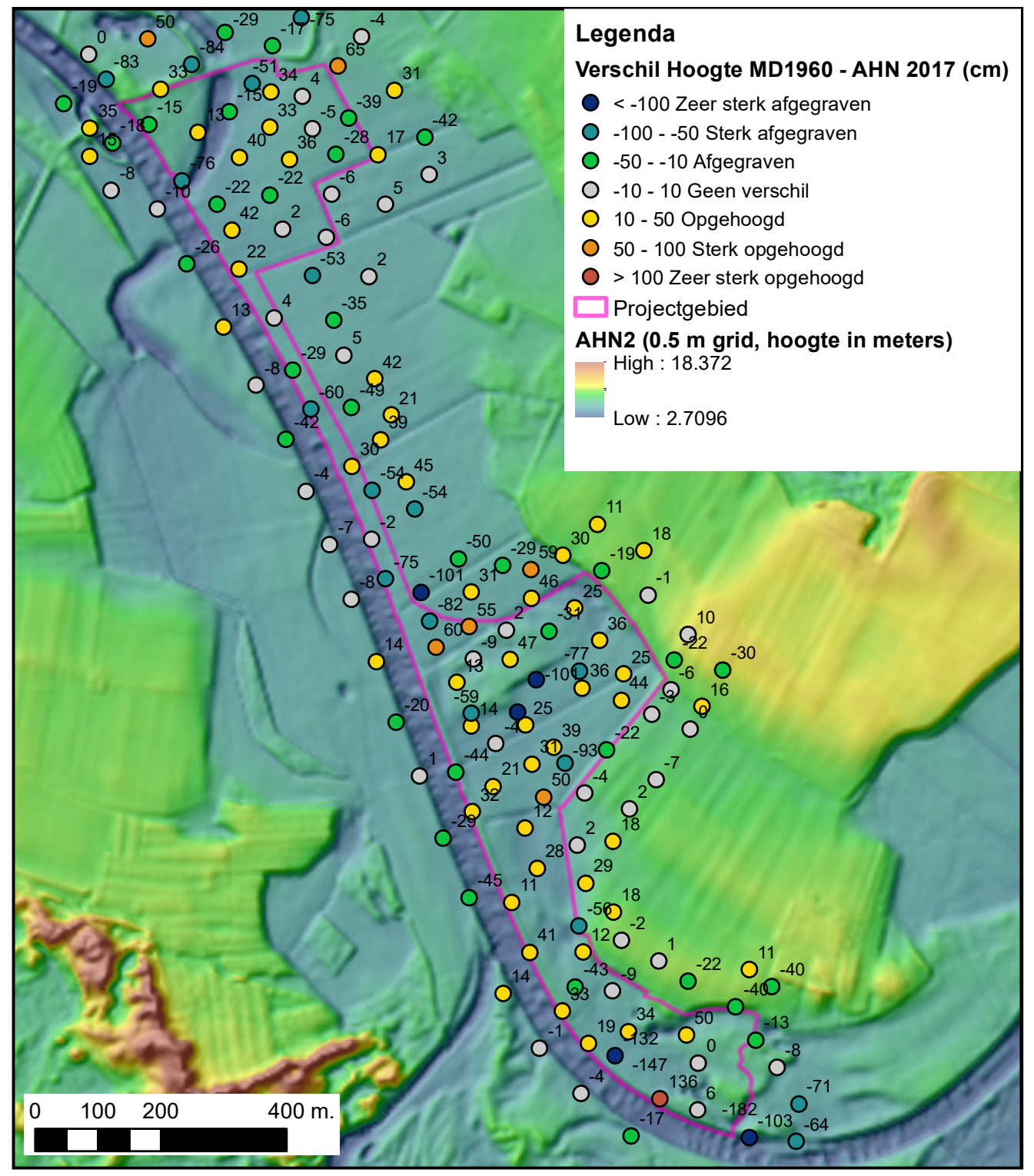

Figuur 2.8 Verschil in maaiveldhoogte tussen 1960 en 2013. 


\section{Legenda}

4 Kade

I III Geplande nevengeul

Vergraven gronden

Geen grondbewerking

E Geëgaliseerd

F Verwerkt

G Afgegraven

H Opgehoogd

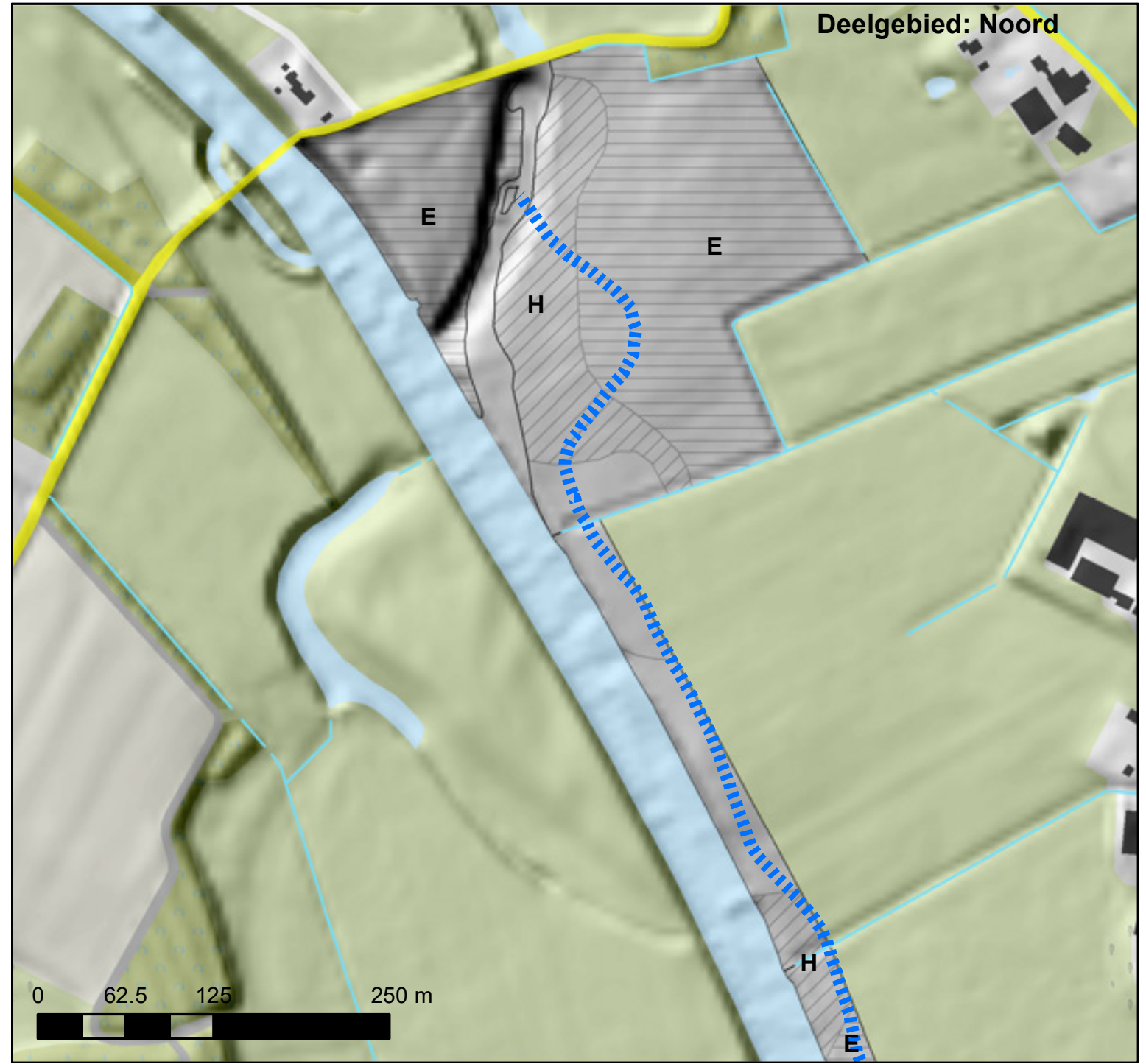

Figuur 2.9a Bodemkaart verwerkte gronden. 


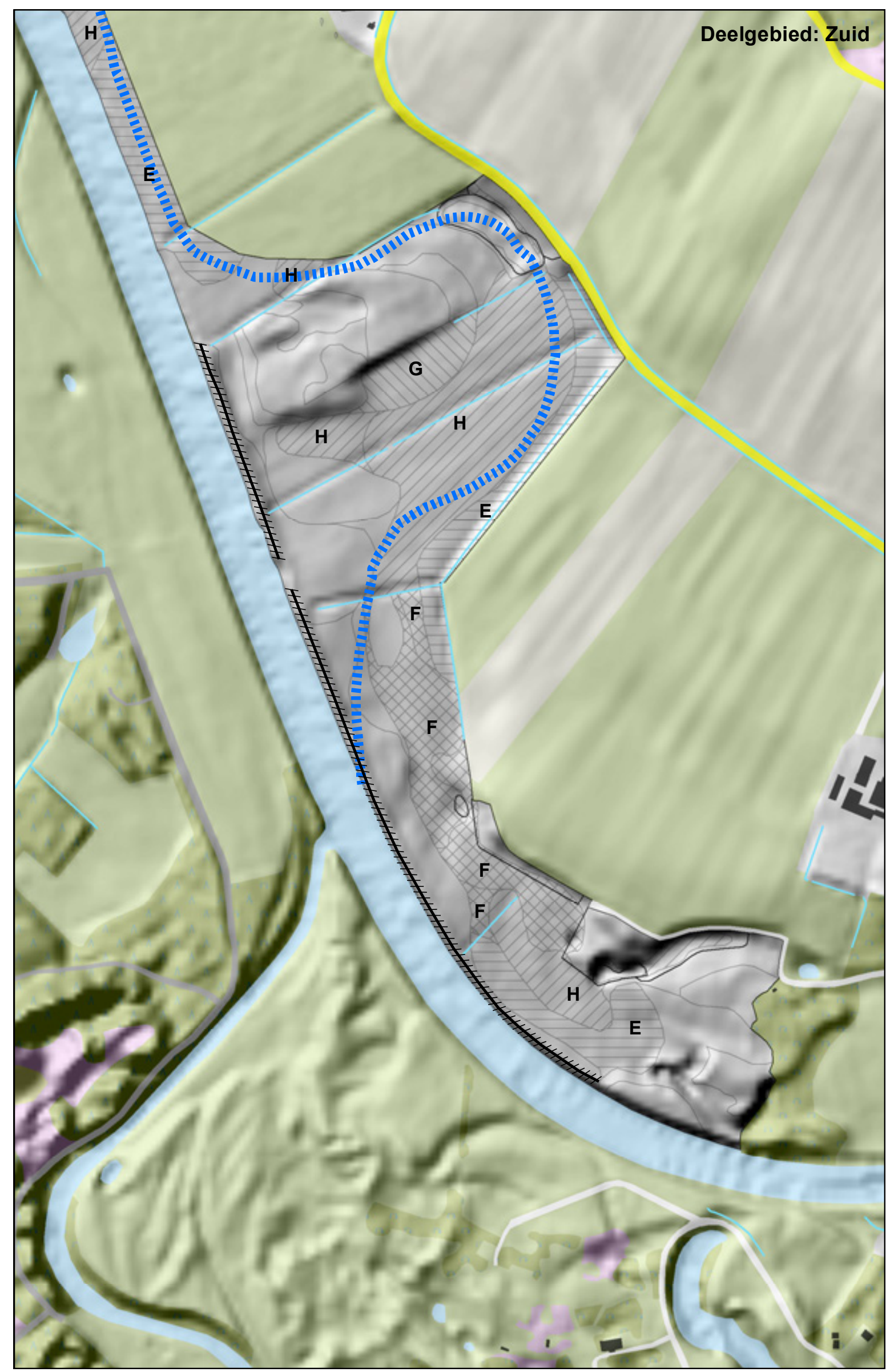

Figuur 2.9b Bodemkaart verwerkte gronden. 


\subsection{Grondwaterstandverloop}

Het grondwaterstandverloop is door middel van grondwatertrappen weergegeven in Figuur 2.11. Peilbuisgegevens waren niet voorhanden, zodat de Gemiddeld Hoogste Grondwaterstand (GHG) en Gemiddeld Laagste Grondwaterstand (GLG) ingeschat zijn op basis van (hydromorfe) profielkenmerken en veldkenmerken (ligging, vegetatie). Wel is in een aantal (18) de grondwaterstand gemeten na minimaal enkele uren ingesteld te zijn. Om de verbreiding van de grondwatertrappen in kaart te brengen, is mede gebruikgemaakt van het AHN.

Het reliëf komt goed tot uiting in de grondwatertrappen, met Gt wIa rondom de oude Vechtarm en IIa in lagere resten van voormalige geulen. In de geëgaliseerde delen komt veelal grondwatertrap IIIa voor. IIIb en Vbo zijn gekarteerd op de oude oeverwallen en de lagere delen van de kronkelwaard. De hogere delen van de kronkelwaard en zandige koppen in het zuidoosten hebben Gt VIo of VIId. In het zuidoostelijke deel komt, tegen de dalwand aan, een vlak voor met Gt Vbd (boring 2033). De ondiepe GHG hier is opvallend gezien de hoge ligging en kan verklaard worden door het voorkomen van pleistocene leem vanaf $90 \mathrm{~cm}-\mathrm{mv}$. Opvallend is ook de groei van Zwarte els op deze kop.
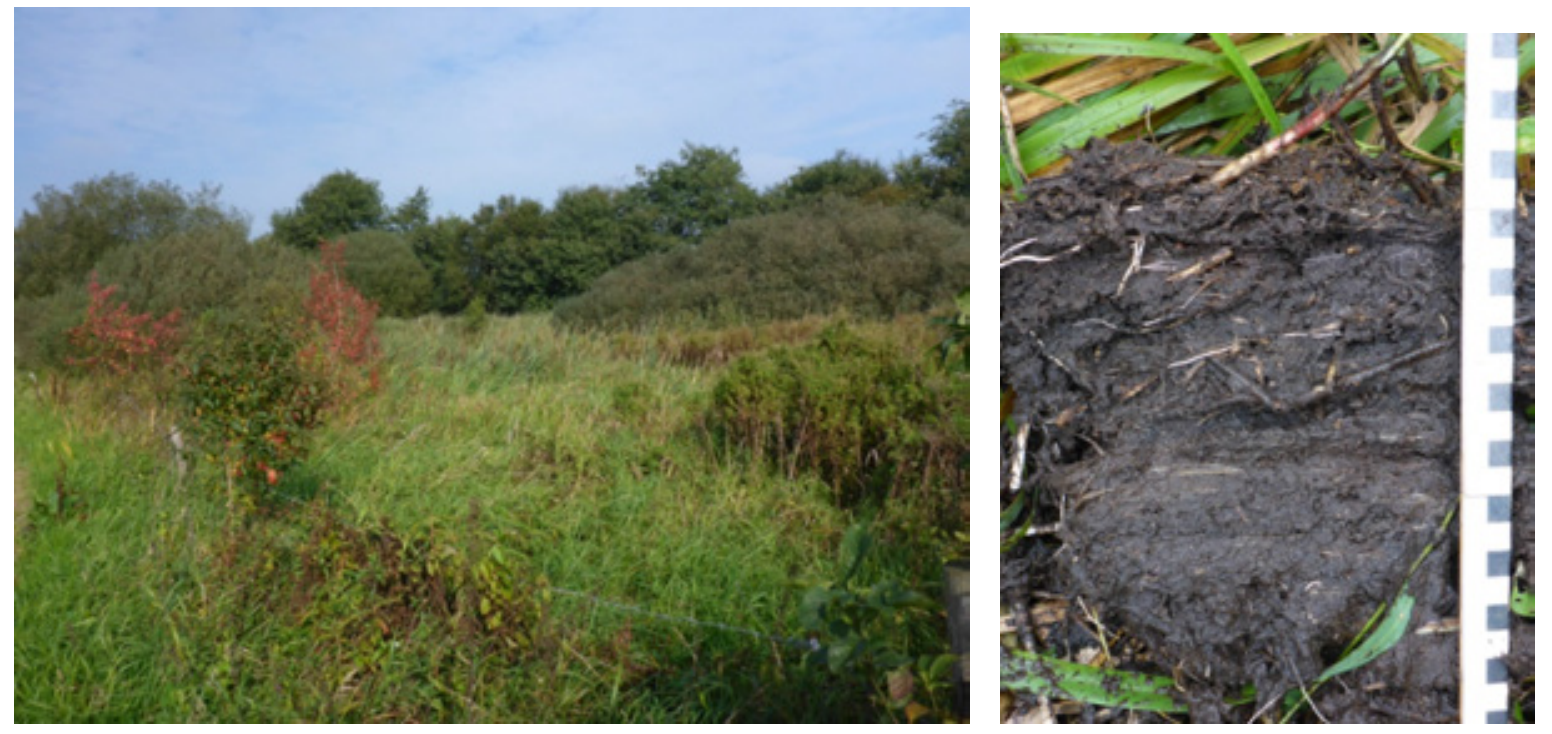

Figuur 2.10 Oeverzone bij de oude Vechtarm met plaseerdgronden (Wo) op grondwatertrap wIa. 


\section{Legenda}

\section{Kade}

IIII Geplande nevengeul

\section{Grondwatertrappen}
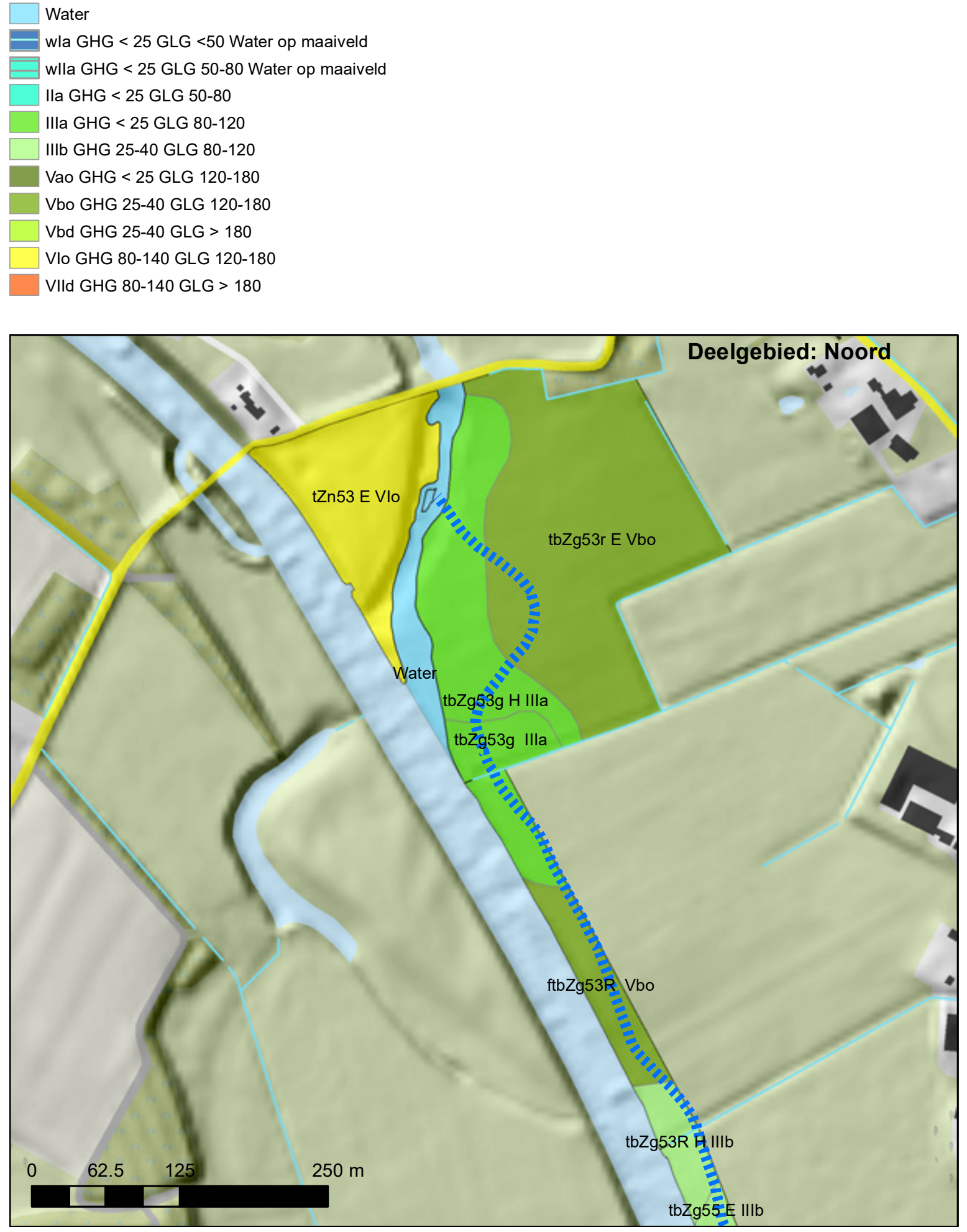

Figuur 2.11a Grondwatertrappenkaart. 


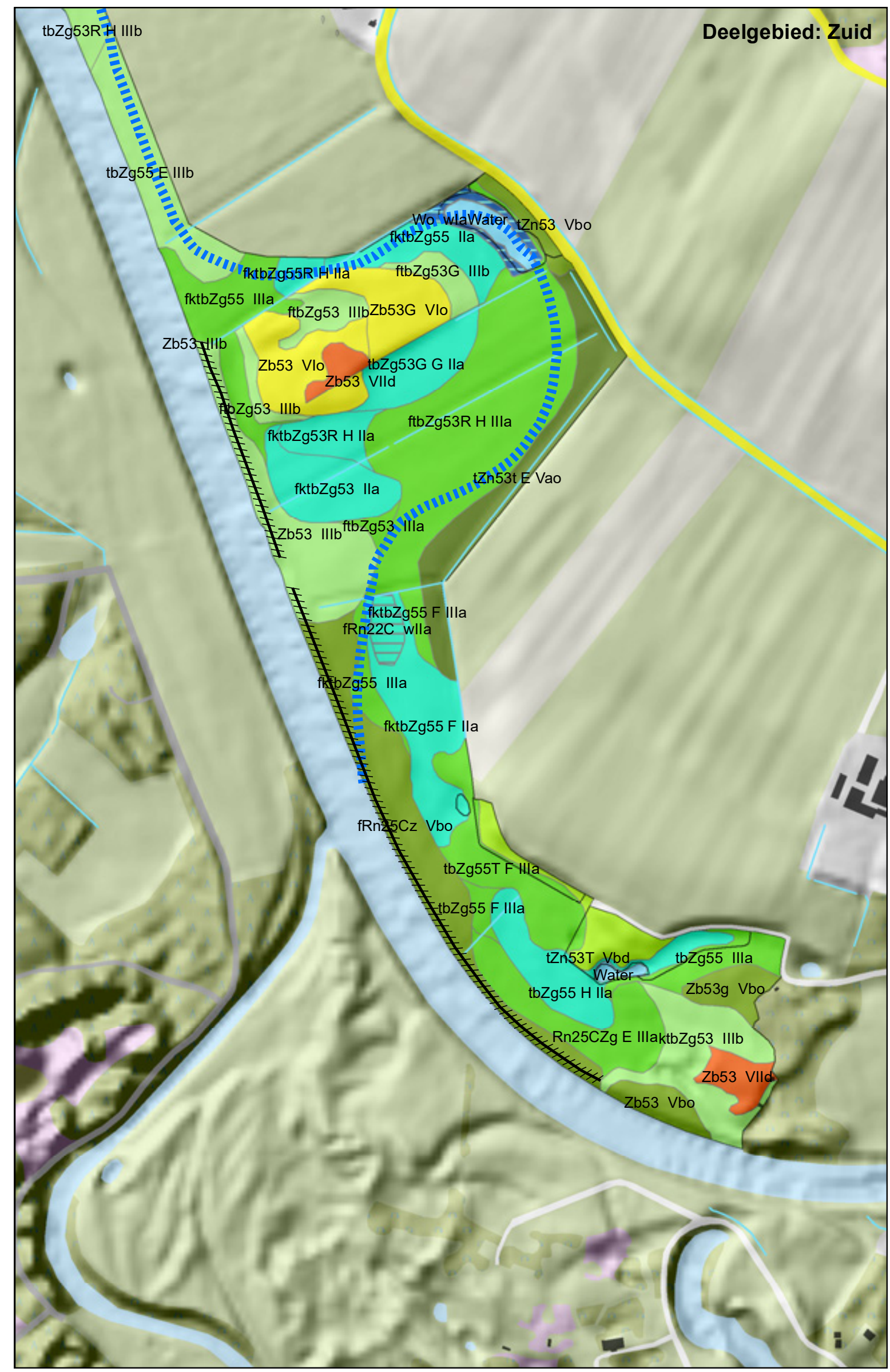

Figuur 2.11b Grondwatertrappenkaart. 


\subsection{Inundatiekarakteristieken}

Voor de ontwikkeling van stroomdalgraslanden speelt ook inundatie een belangrijke rol, omdat hiermee de zuurbuffer van de bodem wordt aangevuld (Jalink et al., 2017). Het gaat daarbij om kortdurende (< 10 dagen) overstroming die jaarlijks of in elk geval vaker dan één keer per vijf jaar in de winter optreedt. Waterkwaliteit is daarbij ook van belang waarbij de nutriëntenbelasting niet te hoog mag zijn, maar wel buffermateriaal (kalk, calcium) wordt aangevoerd. Anderzijds verdragen sommige andere habitattypen inundatie slecht.

De inlaat van de verlengde nevengeul komt ongeveer tegenover de inlaat van de oude meander bij de Prathoek te liggen. In de ecohydrologische verkenning van het Vechtdal (Jalink et al., 2017) is een inschatting gemaakt van de overstromingshoogten en -frequenties voor de Prathoek. Daaruit volgt dat gronden boven $6 \mathrm{~m}$ NAP minder dan één keer per vijf jaar overstroomd raken. Beneden 5,2 m NAP bestaat de kans op inundaties tijden het groeiseizoen. In Figuur 2.12 is de potentiële inundatiefrequentie weergegeven, afhankelijk van de maaiveldhoogte ten opzichte van deze kritische peilen. Werkelijke inundatie zal pas optreden als de oever van de Vecht ter plaatse of verderop ook lager is dan dat peil. Langs een groot deel van deelgebied A ligt een lage kade die hooguit één keer in de 5 à 10 jaar overloopt. Hierin zit echter een onderbreking waar één keer in de 3 à 5 jaar een overschrijding van het peil kan optreden en stroomafwaarts, bij de overgang naar deelgebied $\mathrm{B}$, kan het water één keer in de 2 à 3 jaar binnenstromen. Tijdens een veldbezoek enkele dagen na de hoogwaterpiek in januari 2018 werden bij de eerstgenoemde onderbreking sporen van overstroming waargenomen en in de laagte noordelijk daarvan stond wat water op maaiveld. Dat beeld komt ook terug op de satellietbeelden van die periode (Figuur 2.13). De gebieden die op 8 januari 2018 geïnundeerd zijn, vallen samen met de gebieden die in Figuur 2.12 worden aangeduid met 'ca jaarlijks, mogelijk ook tijdens het groeiseizoen'. Het peil op de Vecht bovenstrooms van de stuw bij Junne bereikte op 5 januari een stand van 5,37 m + NAP (zie Figuur 2.14). Dat is iets lager dan de drempelhoogte volgens AHN (5,8 m +NAP). Het punt ligt $1200 \mathrm{~m}$ stroomopwaarts van de stuw bij Junne, daarbij kan door opstuwing ter hoogte van de verlengde nevengeul een wat hoger peil voorgekomen zijn. Interpolatie van de standen in de Vecht laat zien dat dit tussen de stuw en de Prathoek ongeveer $2 \mathrm{dm}$ kan bedragen. Ook kunnen er afwijkingen in AHN zitten waardoor de hoogte van de drempel is overschat, waardoor in elk geval kortstondig water het perceel is ingestroomd, zoals de waarnemingen in het veld en de satellietbeelden in Figuur 2.13 laten zien. Overschrijdingen van deze hoogtes zijn van korte duur en worden niet in het groeiseizoen verwacht.

Bij aanleg van de verlengde nevengeul met een drempel op 3,70 m +NAP zal inundatie van de lagere delen volgens Figuur 2.12 veel eerder optreden. 


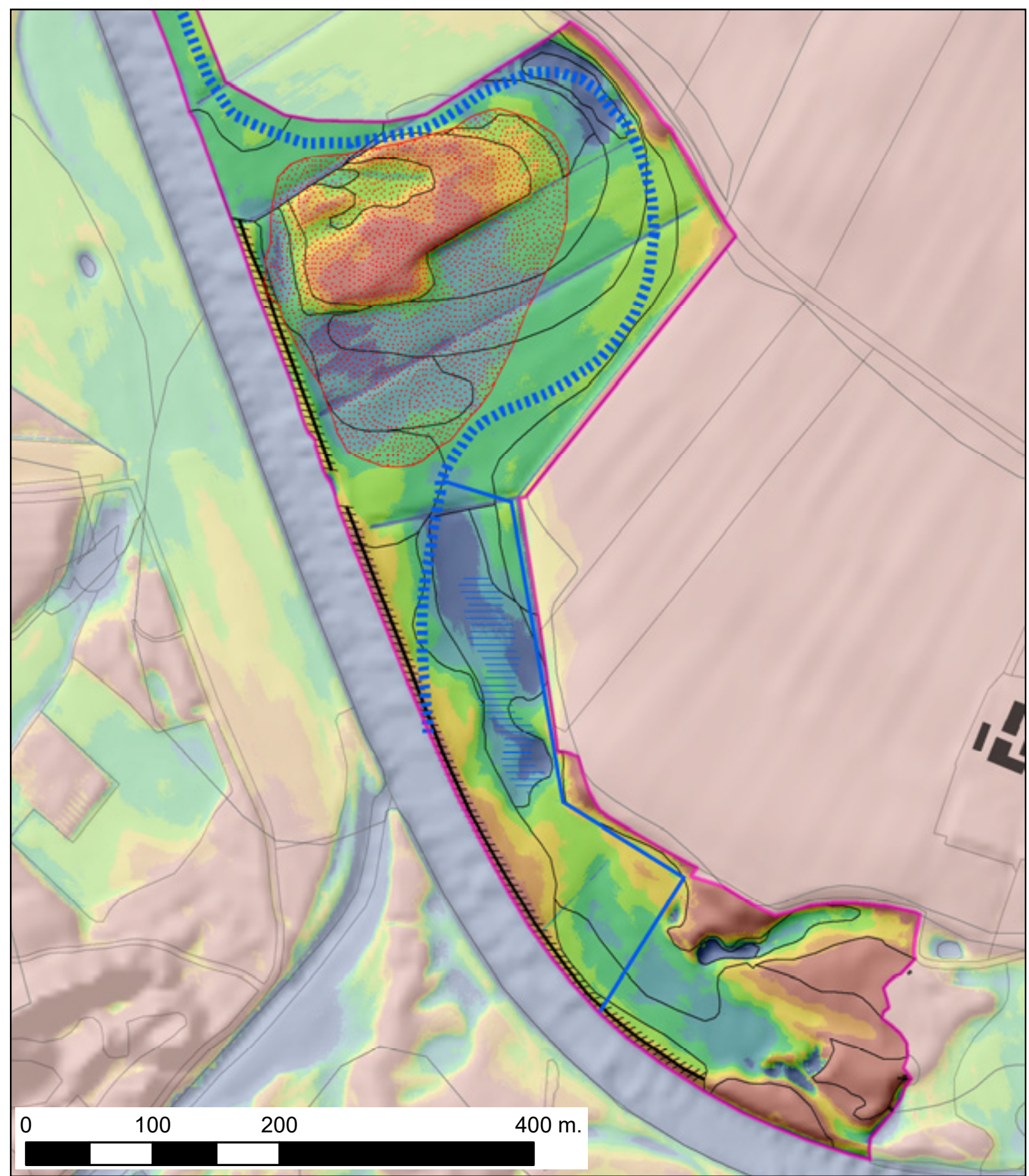

\section{Inrichting}

Deel

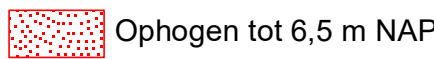

$\overline{\overline{2}}$

IIIIII Geplande nevengeul Visgeul

\section{Kade}

Potentiële inundatiefrequentie, bij vrije toegang Vechtwater.

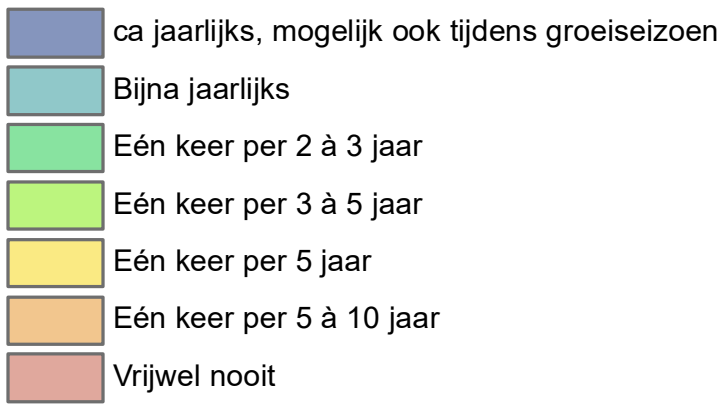

Figuur 2.12 Potentiële inundatiefrequentie, afhankelijk van de maaiveldhoogte en het Vechtpeil (Jalink et al., 2017). Inundatie zal pas optreden als de Vechtoever ter plaatse ook lager is dan het verwachte Vechtpeil of als een laagte in verbinding staat met een lagere oever verderop. 


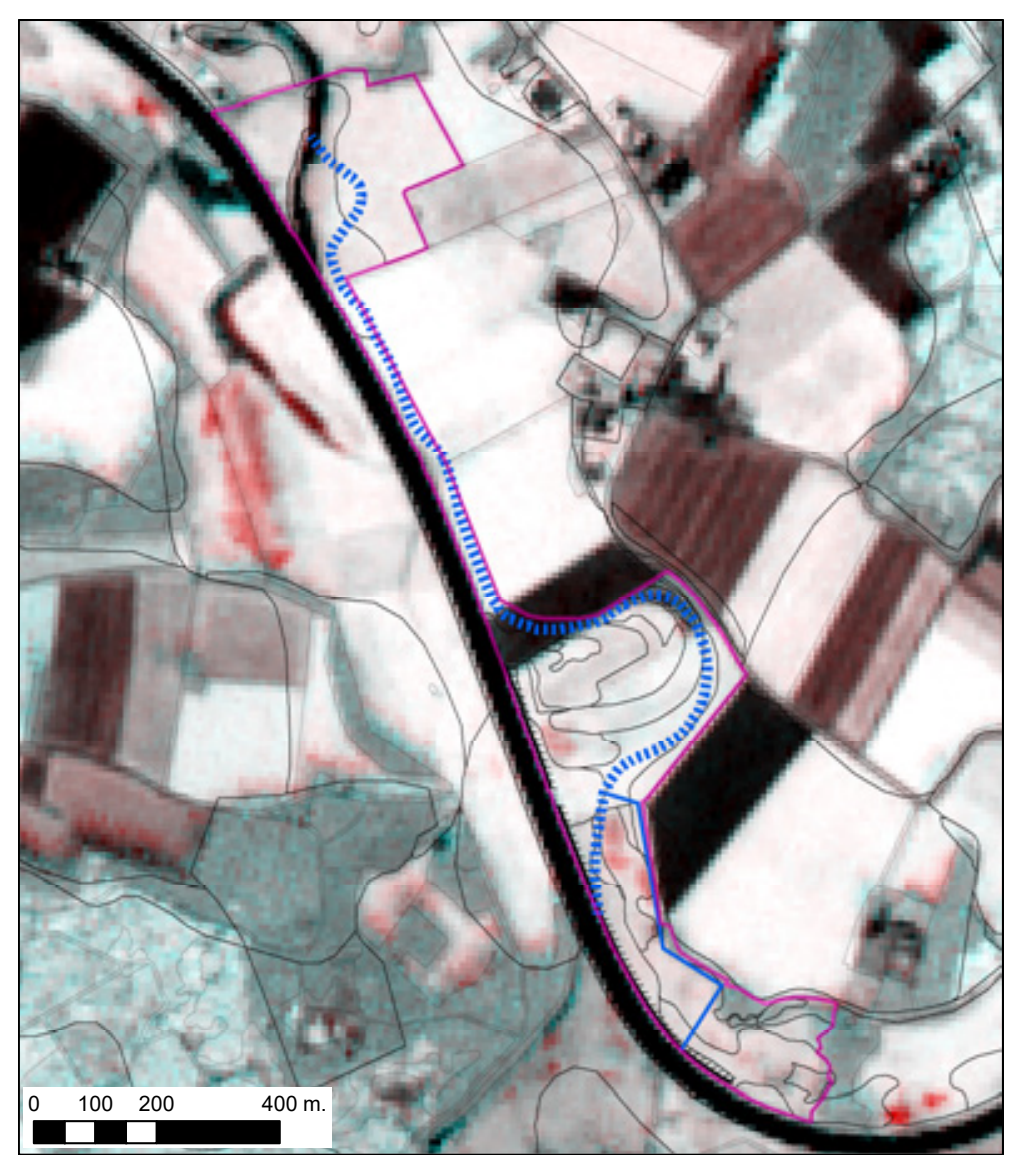

Figuur 2.13 Vergelijking satellietbeelden voor de hoogwatersituatie na zware regenval in januari 2018. De rode vlekken in het Vechtdal geven de plekken aan waar water stond op locaties waar het normaal niet staat.

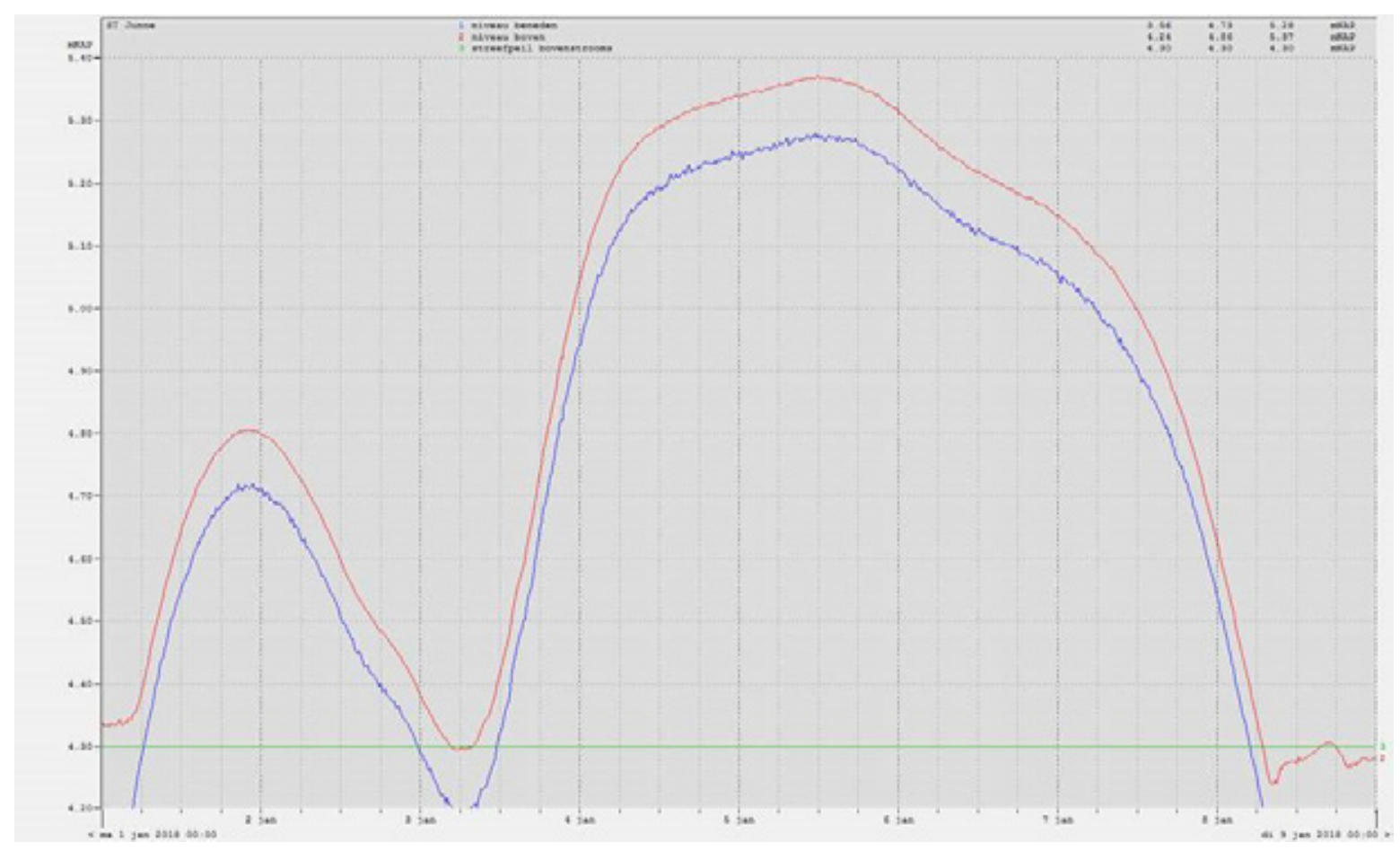

Figuur 2.14 Waterstanden op de Vecht boven- en benedenstrooms van de stuw bij Junne tijdens de afvoergolf in de eerste week van januari 2018 (Bron: Waterschap Vechtstromen). 


\subsection{EGV grond- en oppervlaktewater}

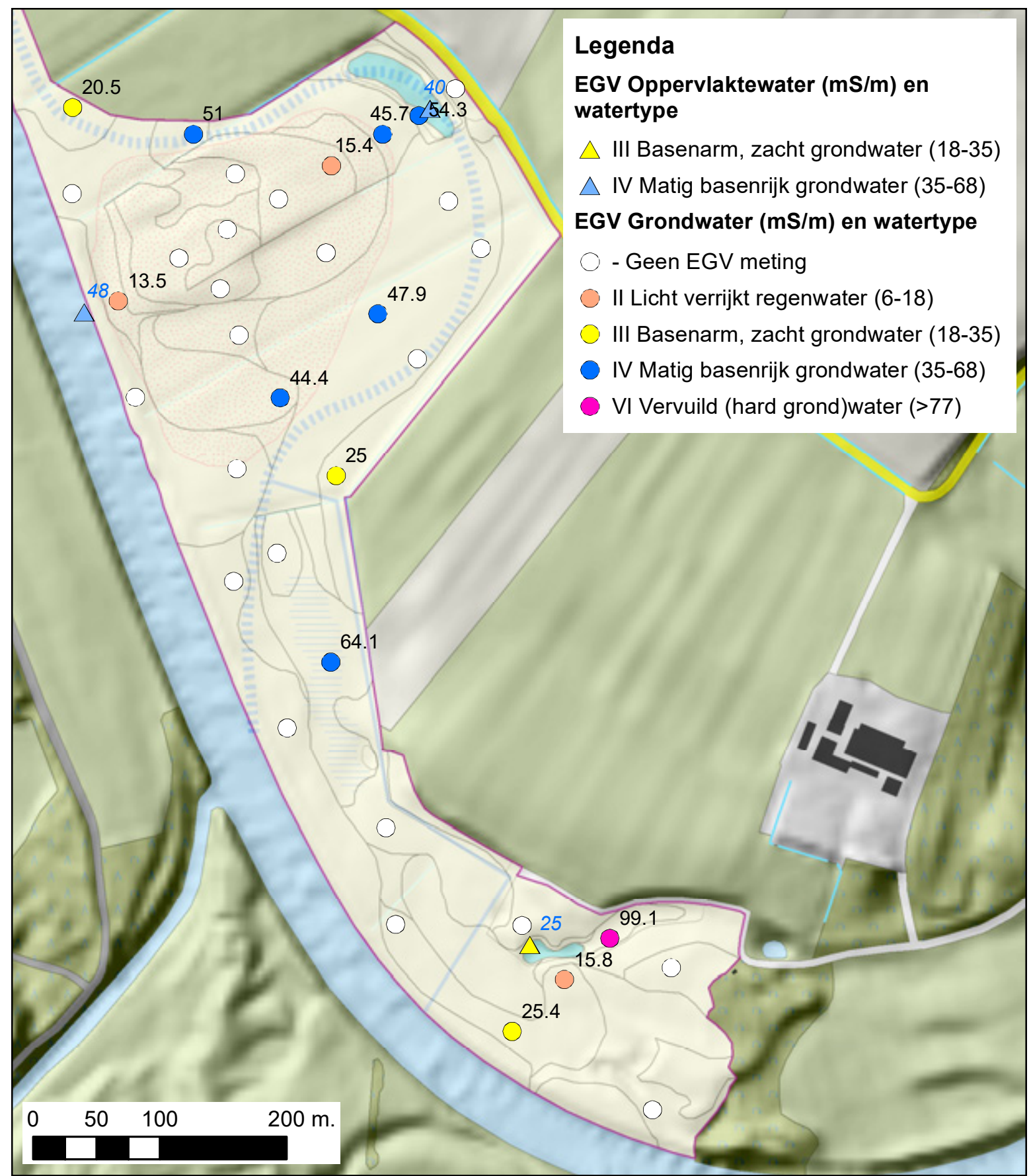

Figuur 2.15 Elektrisch geleidingsvermogen (EGV) in boorgaten en oppervlaktewater met indicatie voor referentiewatertype (Kemmers et al., 2005).

We hebben geen monsters genomen van grond- en oppervlaktewater, maar kunnen uit veldwaarnemingen van EGV en pH-profielen (zie § 2.10) wel een inschatting maken (Figuur 2.15). De waterkwaliteit voor natuurontwikkeling kan getypeerd worden met behulp van het elektrisch geleidingsvermogen (EGV). Deze kan eenvoudig in het veld worden bepaald. Aan de hand van het EGV kunnen vier hoofdwatertypen worden onderscheiden: regenwater, basenarm zacht grondwater, matig basenrijk grondwater en hard (vervuild) grondwater. Tussen deze hoofdtypen kunnen allerlei mengtypen voorkomen. In het bereik van de restgeul van de Vechtarm kan de waterkwaliteit getypeerd worden als matig basenrijk grondwater, een indicator voor kwel. Wat hoger op de flank van de dalrand/oeverwal is sprake van basenarm, zacht grondwater. In de kronkelwaard/rivierduin binnen de oude Vechtarm is sprake van een regenwaterinfiltratieprofiel. 
Hard (vervuild) grondwater wordt aangetroffen in een restgeul in het meest stroomopwaartse deel van het deeltraject. Hier is mogelijk sprake van uitspoeling van nutriënten vanuit de voormalige boerderij op het terras. Omdat dit een grondwaterstroom over een korte afstand betreft en het bedrijf niet meer actief is, zal naar verwachting de waterkwaliteit op termijn verbeteren. De snelheid waarmee dat gebeurt, zal afhankelijk zijn van de mate van verontreiniging en de binding aan bodemmateriaal.

\section{$2.10 \quad \mathrm{pH}$-profiel}

In deelgebied $\mathrm{A}$ is bij 15 boorpunten ook het pH-profiel opgenomen door op 4 à 10 dieptes de $\mathrm{pH}$ van het bodemmateriaal te bepalen met indicatorstrookjes (zie transect Figuur 2.16). De metingen zijn bij voorkeur uitgevoerd op locaties waar kwel, gezien het bodemprofiel en de landschappelijke ligging, mogelijk aan de orde is, maar ook op enkele hoger gelegen locaties om de gradiënt beter in beeld te krijgen en inzicht te krijgen in de zuurgraad van de potentiële groeiplaatsen voor stroomdalgrasland.

De aan de bodem gemeten $\mathrm{pH}$ is representatief voor de bodemmatrix en daardoor vrijwel niet seizoensafhankelijk, in tegenstelling tot de $\mathrm{pH}$ van het bodemwater. De op deze wijze bepaalde $\mathrm{pH}$ waarden komen redelijk overeen met $\mathrm{pH}-\mathrm{KCl}$ zoals in het laboratorium gemeten wordt, maar liggen wel iets hoger. Bij de interpretatie is daarvoor gecompenseerd.

\section{Transect R3 - pH-profielen}

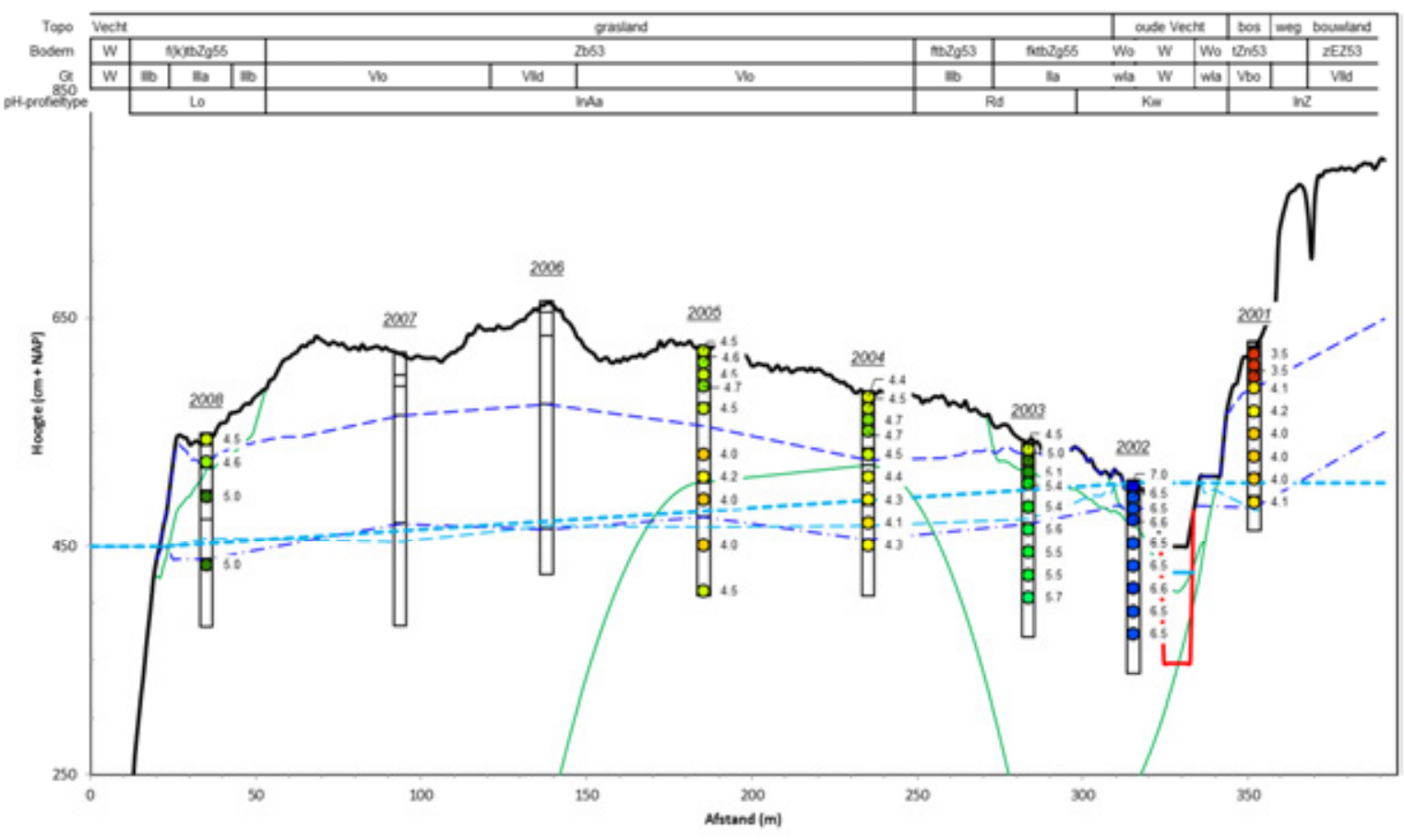

Figuur 2.16 Transect 3 met pH-profielen en pH-profieltypen (zie Tabel 2.1). 


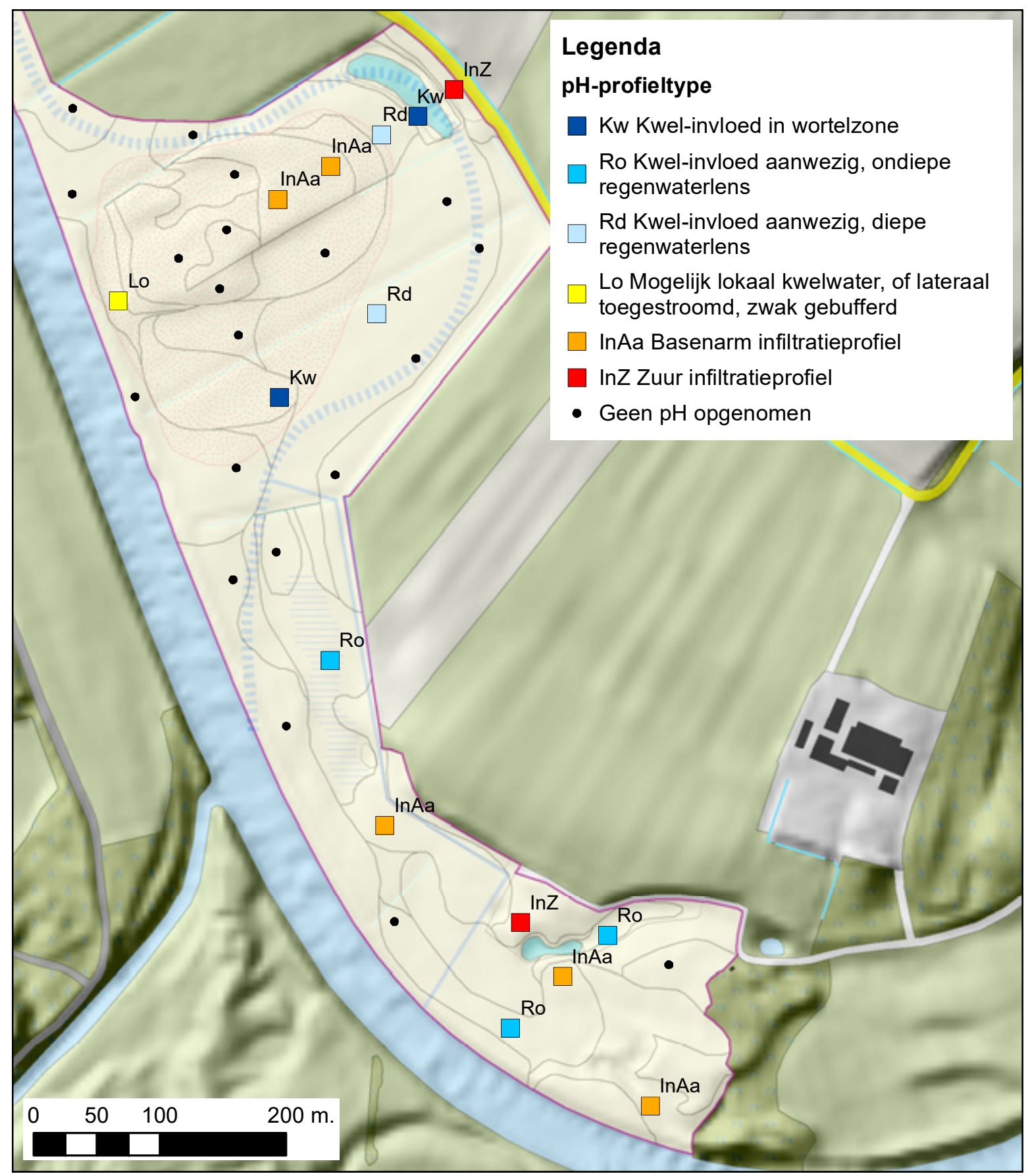

Figuur 2.17 pH-profieltypen in de boringen, indeling op basis van $\mathrm{pH}$-verloop met de diepte volgens sleutel in Tabel 2.1.

De $\mathrm{pH}$-profielen geven een indicatie voor het voorkomen van kwel in de wortelzone. Hiervoor is een sleutel afgeleid waarmee op basis van de $\mathrm{pH}$-waarden op verschillende diepten bepaald wordt of kwel voorkomt en van invloed is in het profiel (Tabel 2.1). De vijftien boringen waar pH-metingen gedaan zijn, zijn volgens deze sleutel ingedeeld in $\mathrm{pH}$-profieltypen, variërend van 'Kwelinvloed in de wortelzone' tot een 'Zuur infiltratieprofiel'. Bij twee profielen is kwel tot in de wortelzone gevonden (Figuur 2.17). Deze profielen liggen in het bereik van de laagste delen van de opgevulde restgeul van de voormalige Vechtmeander. Bij drie profielen, in laagten tegen de flank van de dalrand of oeverwal, komt een ondiepe neerslaglens voor en bij twee profielen een diepe. Het boorpunt in het transect dicht langs de Vecht heeft kenmerken van rivierkwel. De overige profielen hebben allemaal een infiltratieprofiel. Bij boringen met een neerslaglens wijst de gemeten EGV ook in de richting van gebufferd grondwater, maar dit water heeft geen invloed in de wortelzone, omdat het verdrongen wordt door infiltrerend neerslagwater. 
Tabel 2.1 Sleutel voor het bepalen van het pH-profieltype, naar Van Delft \& Kemmers (2013), uitgebreid voor infiltratieprofielen. Op basis van de vergelijking tussen kritieke Z-afstand (Zk) en de GLG kan nagegaan worden of contact tussen (al of niet gebufferd) grondwater en de wortelzone (via capillaire nalevering) te verwachten is (Kemmers et al. 2005).

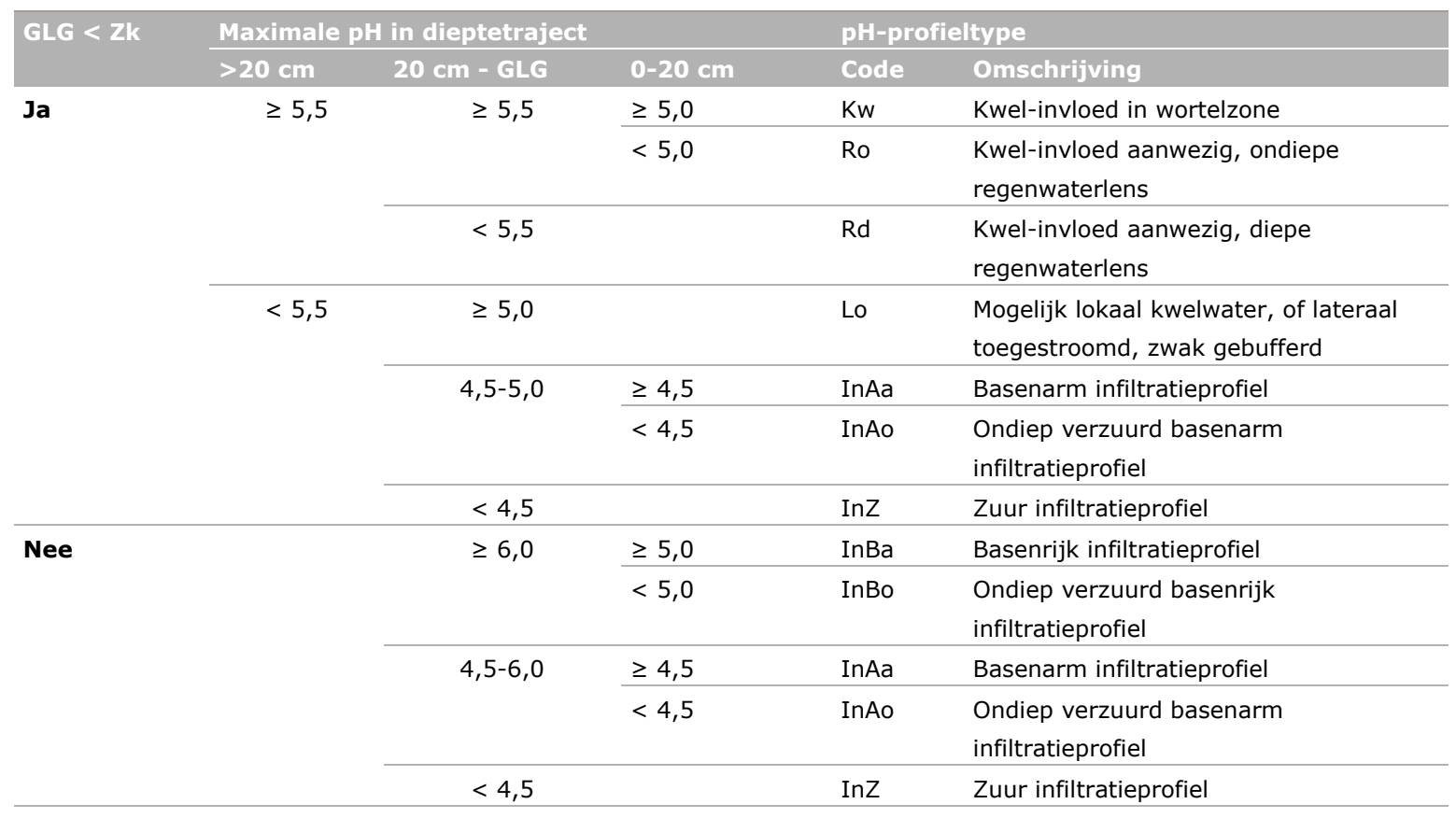




\section{Ontwerp nevengeul, bodemsubstraat en grondwatersituatie}

\subsection{Transecten}

Een deel van de boringen is gebruikt voor het uitwerken van transecten voor de bodem- en grondwatersituatie langs de ontwerp nevengeul. De ligging van de transecten is aangegeven in Figuur 3.1. In Figuur 3.2 en Figuur 3.3 is een lengteprofiel uitgetekend langs het tracé van de geplande verlengde nevengeul en in Figuur 3.4 een dwarsprofiel van de Vecht, door de kronkelwaard en de oude Vechtarm tot op de es bij de Spijkerweg. In de drie transecten zijn de geologische pakketten weergegeven en het grondwaterstandverloop (GHG, GLG) en de grondwaterstanden (GWS) tijdens het veldwerk. Om een indruk te krijgen van de afzettingen waar de nevengeul doorheen gegraven wordt, is ook de ontwerp bodemhoogte van de nevengeul ingetekend, samen met het peil in de geul en de Vecht (huidige drainagebasis).

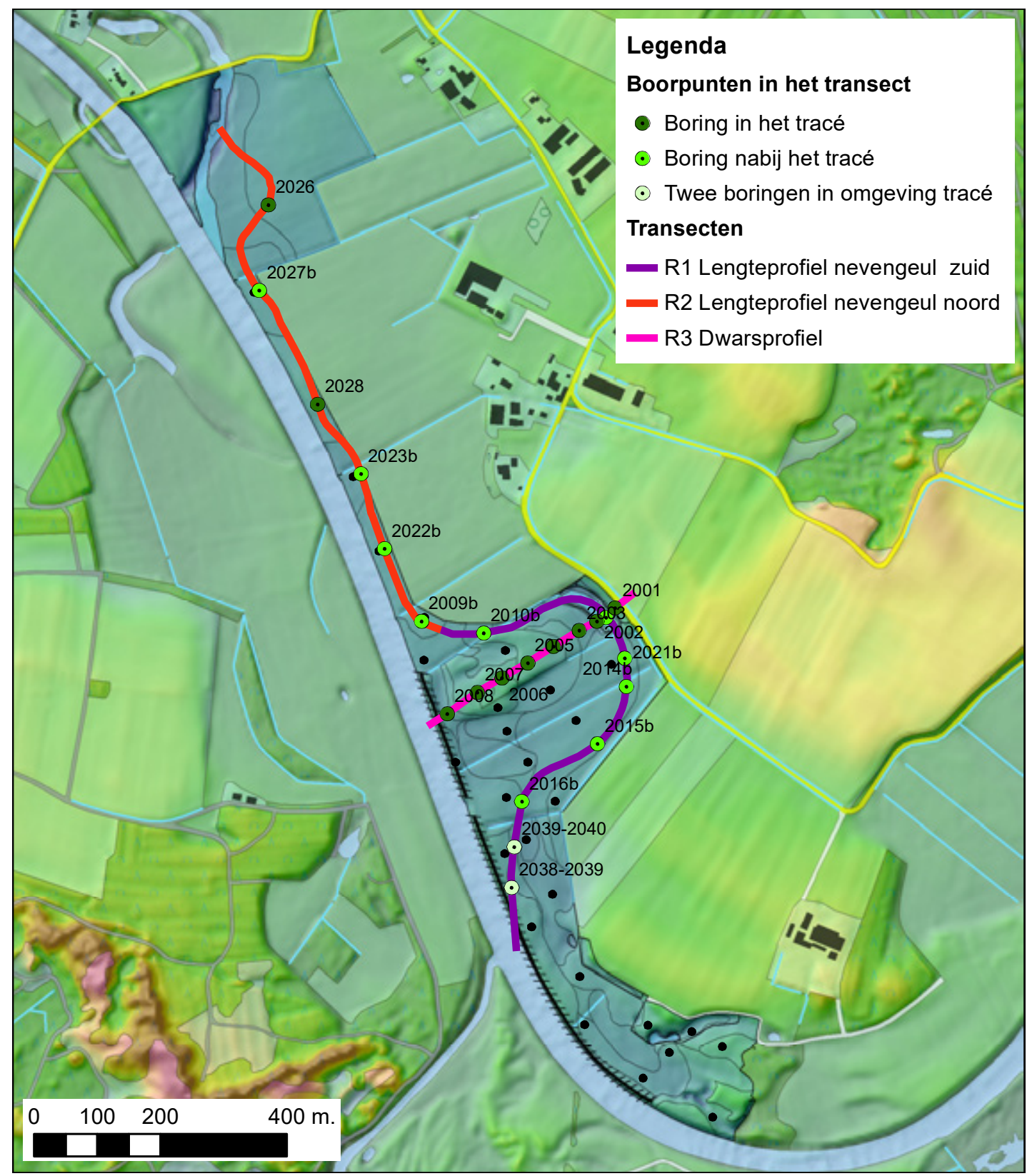

Figuur 3.1 In de transecten gebruikte boringen (toelichting zie tekst). 
Voor boringen in de nabijheid van het tracé zijn de begindiepten van afzettingen aangepast aan het verschil in maaiveldhoogte tussen de locatie van de boring en het punt in het tracé; bij twee punten in het tracé is gebruikgemaakt van gegevens uit twee boringen in de omgeving, waarbij de begindieptes door interpolatie zijn ingeschat.

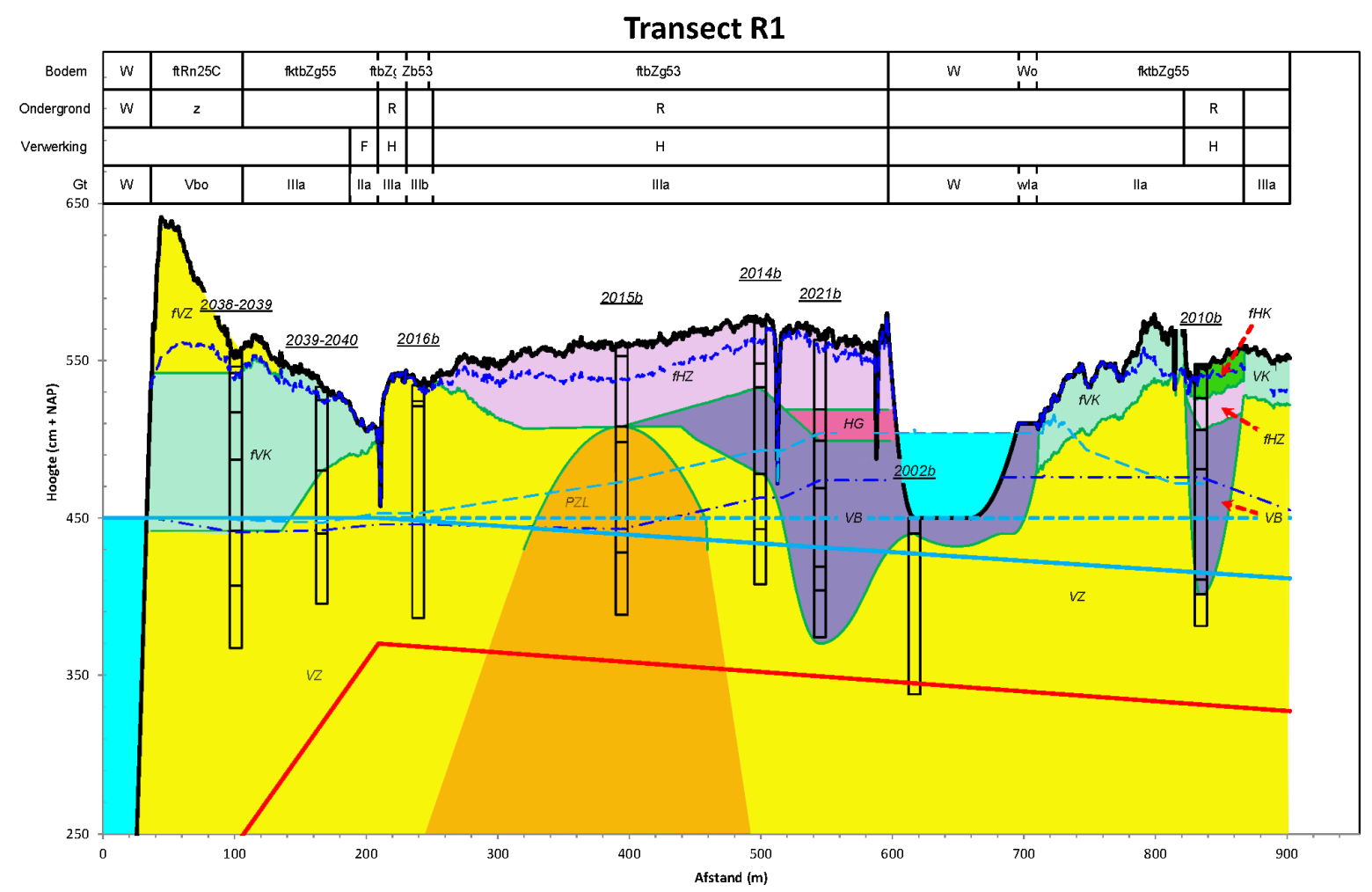

Figuur 3.2 Lengteprofiel in transect R1, in deelgebied A van de verlengde nevengeul (zie Figuur 3.1 en Tabel 3.1).

De rode lijn in de figuur is de ontwerp verhanglijn van de bedding van de nevengeul en de doorgetrokken blauwe lijn de ontwerp waterspiegelverhanglijn. De knik in de beddingverhanglijn (ca. $200 \mathrm{~m}$ ) geeft de positie van het inlaatwerk van de nevengeul weer. Het waterpeil in de geul voor het inlaatwerk is gelijk aan het waterpeil op de Vecht. Vanaf het inlaatwerk ligt de ontwerp spiegelverhanglijn ca. $80 \mathrm{~cm}$ boven de beddingverhanglijn. Het peil van de Vecht $(4.50 \mathrm{~m}+\mathrm{NAP})$ is het huidige winterstuwpeil Junne dat als randvoorwaarde aan het ontwerp van de nevengeul is meegegeven.

Tabel 3.1 Legenda voor de transecten (Figuur 3.2, 3.3 en 3.4).

\begin{tabular}{|c|c|}
\hline \multicolumn{2}{|c|}{ Legenda } \\
\hline$\underline{203}$ & Meetpunt \\
\hline Ah $\square$ & $\begin{array}{l}\text { Bovengrens geologisch pakket } \\
\text { Bodemhorizont }\end{array}$ \\
\hline & Maaiveld \\
\hline$---\infty$ & GHG \\
\hline$-\cdot \cdot \cdot \cdot-$ & GLG \\
\hline---- & GWS \\
\hline & $\begin{array}{l}\text { Bodem geul } \\
\text { Peil geul }\end{array}$ \\
\hline -ーーーー & Drainagebasis \\
\hline$f V Z$ & Label \\
\hline $\mathrm{w}$ & Kenmerken langs het transect \\
\hline
\end{tabular}

\begin{tabular}{l} 
Vechtafzettingen \\
VK Klei \\
VZ Zand \\
VG Grof zand \\
VB Beddingmateriaal, meestal niet gerijpte klei en veen \\
Pleistocene afzettingen \\
PZL Zand met leemlagen \\
Opgebracht of geëgaliseerd, doorgaans heterogeen \\
HK Klei \\
HZ Zand \\
HG Grof zand \\
HKM Klei en veen \\
\hline Toevoeging \\
f IJzerrijke laag
\end{tabular}




\section{Transect R2}

\begin{tabular}{|c|c|c|c|c|c|c|c|}
\hline $\begin{array}{c}\text { Bodem } \\
\text { Ondergrond }\end{array}$ & tozg55 & RktbZg53 & $\mathrm{ftbZg53}$ & \multicolumn{2}{|c|}{ tbZg53 } & $\mathrm{fbZZg53}$ & tbZg53 $W$ \\
\hline & E & $H$ & & & $\mathrm{H}$ & E & H \\
\hline
\end{tabular}

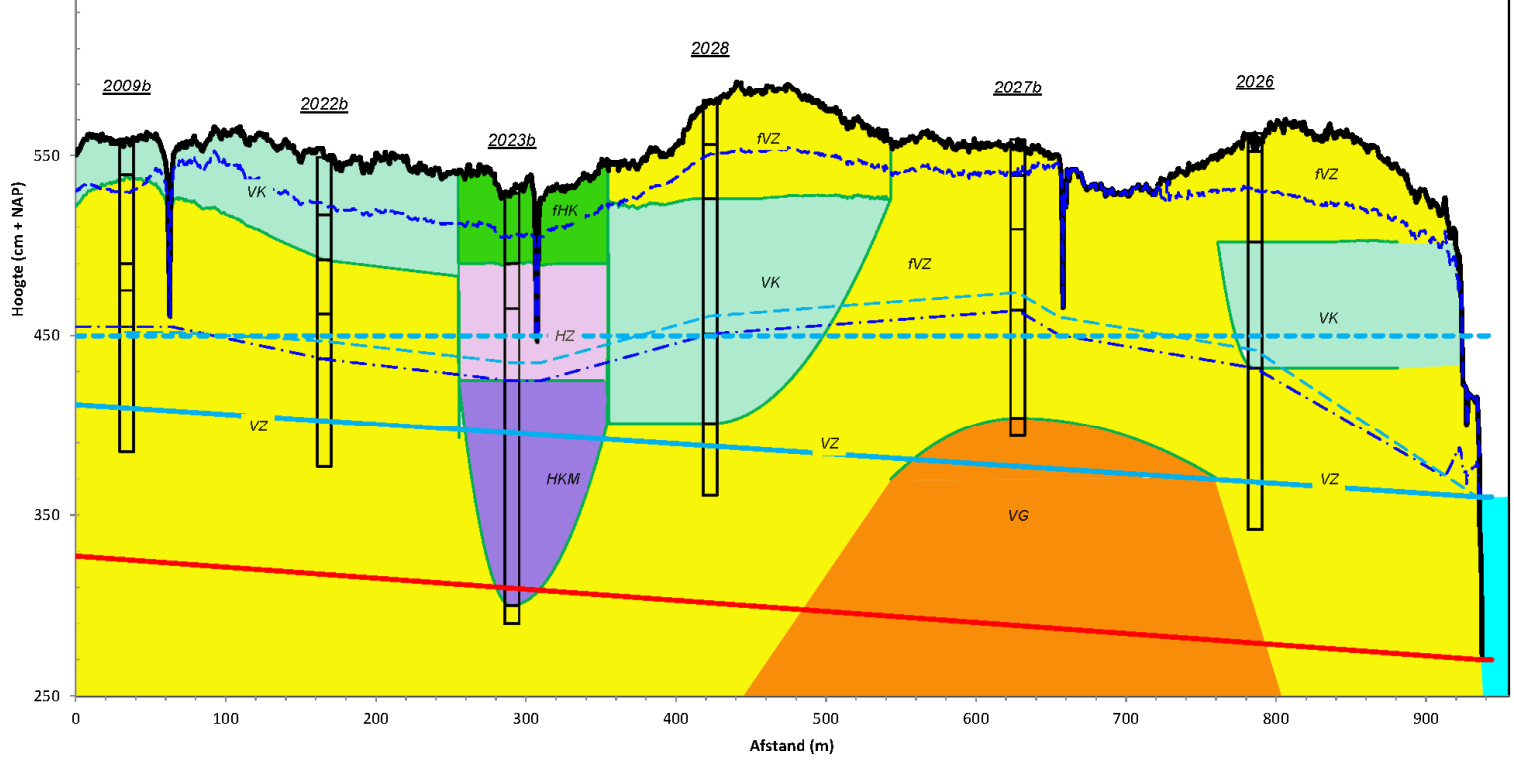

Figuur 3.3 Lengteprofiel in transect R2, deelgebied B en C van de verlengde nevengeul (zie Figuur 3.1 en Tabel 3.1).

\section{Transect R3}

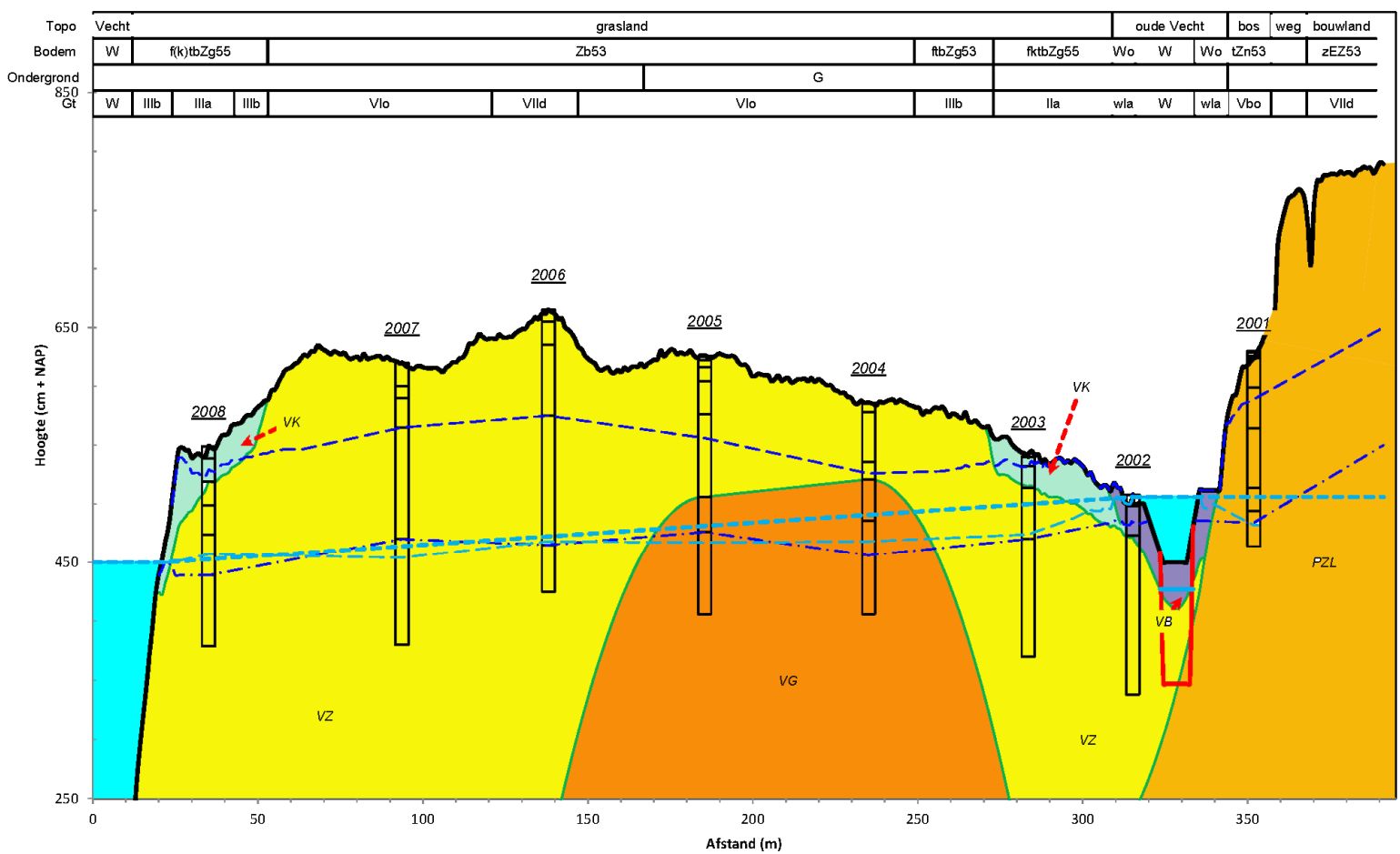

Figuur 3.4 Dwarsprofiel in transect R3, van de Vecht door de oude Vechtarm tot de hogere gronden buiten het winterbed (zie Figuur 3.1 en Tabel 3.1). 


\subsection{Deeltraject A (transect R1 en R3)}

- De bedding van de nevengeul komt voornamelijk in zandige, ijzerrijke vechtafzettingen te liggen (textuur: M50 130-180 $\mu$ m leemgehalte 6-25\%) met af en toe een leemlaag (boring 2015).

- De bedding van de nevengeul komt onder het niveau van de bedding van de restgeul van de oude arm van de Vecht te liggen.

- Vanaf de Vecht tot aan het inlaatwerk bestaat het deel van de oever van de geul boven de waterspiegel uit klei (VK; boring 2038-2040).

- Na het inlaatwerk snijdt de nevengeulbedding pleistoceen zand en leem aan (boring 2015b), dit is ook mogelijk elders in de buurt van de dalrand (terras). Ook de oevers bestaan hier deels uit pleistoceen zand met leemlagen.

- Vanaf boring 2014b t/m 2010b komt de ontwerp nevengeul in kleiige/venige geulopvullingen in de restgeul van de oude Vechtarm te liggen. De bedding van de ontwerp nevengeul ligt minimaal $20 \mathrm{~cm}$ onder het niveau van restgeul in zandige vechtafzettingen. In dit deel van het tracé van de nevengeul bestaan de oevers grotendeels uit kleiig/venig beddingmateriaal. In de delen waar de nevengeul net buiten de loop van de restgeul komt te liggen, bestaat de bodem uit vechtzand (Vz) met een dun kleidek (Vk) (weerszijde boring 2010b).

- Tussen boring $2016 \mathrm{~b}$ en $2002 \mathrm{~b}$ is over de restgeulafzettingen 40 à $50 \mathrm{~cm}$ zand opgebracht ( $\mathrm{H}$ op de kaart verwerkte gronden), waarschijnlijk door een deel van de naastgelegen kronkelwaard/rivierduinen af te graven. Ter hoogte van boring 2021b bestaat het opgebrachte materiaal tussen 40-60 cm min maaiveld uit grof zand.

- Het huidige oppervlaktewaterpeil in het niet opgevulde deel van de restgeul lag ten tijde van het veldwerk $50 \mathrm{~cm}$ boven het Vechtpeil (4.50 m +NAP).

- Het peil in de nevengeul komt stroomafwaarts van het inlaatwerk in dit deeltraject tussen de 0 en $80 \mathrm{~cm}$ onder de huidige GLG te liggen en tussen de 0 en $40 \mathrm{~cm}$ beneden het peil van de Vecht.

- De gemiddeld laagste grondwaterstand (GLG) wordt grotendeels bepaald door het Vechtpeil. De invloed neemt af met afstand tot de Vecht; de grondwaterstanden (GHG en GLG) staan langs de dalrand onder invloed van het grondwaterpeil in het hoger gelegen pleistocene terras (kwel).

- Ter hoogte van de oude Vechtarm komt het peil in de nevengeul ca. $80 \mathrm{~cm}$ lager te liggen dan het gemeten oppervlaktewaterpeil tijdens het veldwerk (september 2017).

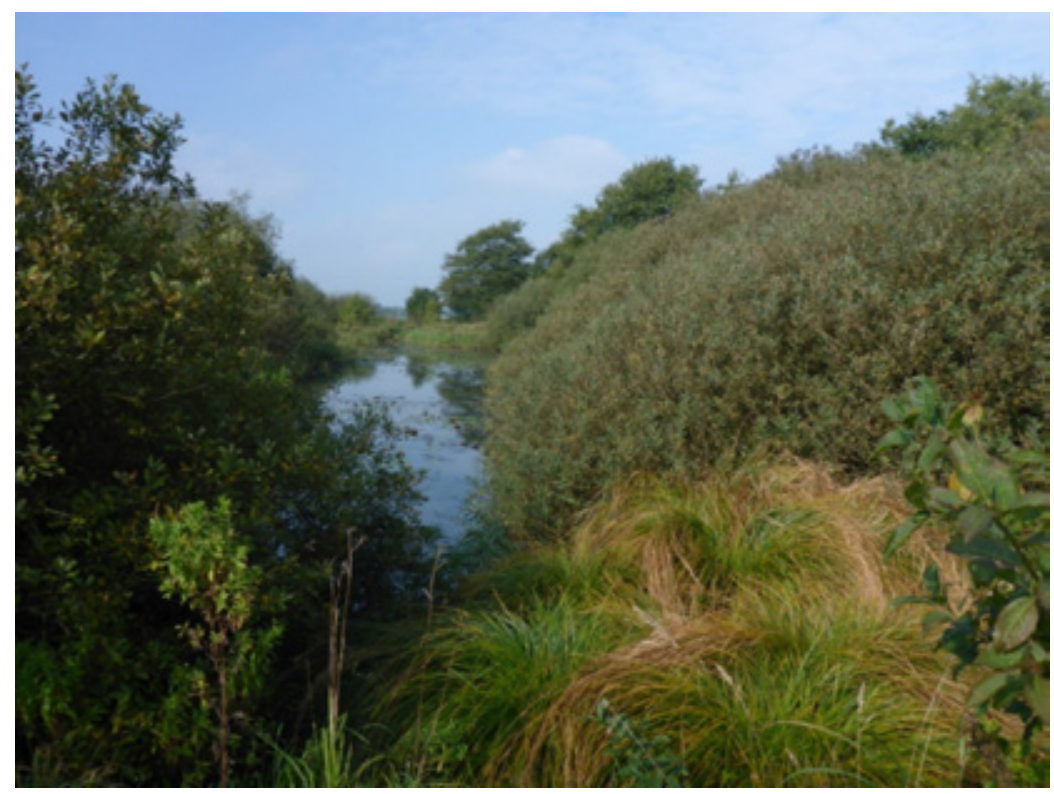

Figuur 3.5 Restgeul oude Vechtarm bij de Spijkerweg. 


\subsection{Deeltraject B en C (transect R2)}

- De bedding van de nevengeul komt voornamelijk in zandige, ijzerrijke vechtafzettingen te liggen (textuur: M50 160-220 $\mu \mathrm{m}$, leem 4-12\%).

- Ter hoogte van boring 2023b snijdt de ontwerp nevengeul opnieuw een oude restgeul van de Vecht aan. De geulopvulling bestaat ook hier uit niet-gerijpte klei en veen en is slap.

- De bedding van de nevengeul komt in dit deel van het tracé niet onder het niveau van de voormalige bedding van de Vecht te liggen.

- Op de overgang van deeltraject B naar $C$ liggen de bedding en een deel van de oevers van de ontwerp nevengeul in grof rivierzand (boring 2027b en mogelijk ook bij 2026b).

- De bovengrond bestaat, met uitzondering van het gedeelte van het geultracé rond boring 2027b, uit een 40 tot $120 \mathrm{~cm}$ dikke kleilaag, komafzettingen van de Vecht. Bij 2023 is de kleilaag boven restgeul zelfs zeer stug.

- Peil in geul komt stroomafwaarts van boring 2009b 40 à $80 \mathrm{~cm}$ onder de huidige GLG/peil van de Vecht te liggen.

\subsection{Conclusies}

De bedding van de ontwerp nevengeul ligt vrijwel het gehele tracé in zandige Vechtafzettingen. In deeltraject $A$ snijdt de bedding tegen de dalrand pleistoceen zand met leemlagen aan. De oevers van de ontwerp nevengeul, vooral het deel boven de gemiddelde waterspiegel, liggen in deeltraject $A$ geheel of gedeeltelijk in venig en kleiig substraat. Dit betreft zowel gerijpte kleidekken als ongerijpte restgeulvullingen. Het cohesieve karakter van de bodem in de oeverzone van de nevengeul heeft een stabiliserende werking op potentiële morfologische processen in de geul. Naarmate de breedtediepteverhouding van een geul kleiner is, is de invloed van de oevers op de hydro-morfologische geulprocessen groter. Laterale verplaatsing van de geul is op grond van de samenstelling van de bodem in de oeverzone en de relatief geringe breedte-diepteverhouding van de geul in deeltraject $A$ niet of nauwelijks te verwachten. Discontinuïteiten in de bodem kunnen lokaal leiden tot oevererosie en ondergraven oevers, maar grosso modo zal de nevengeul vrij stabiel in de dalvlakte liggen. In tegenstelling tot laterale verplaatsing kan de ontwerpgeul wel verticaal eroderen en zou de bedding zich kunnen verdiepen. Dit proces zal gaan optreden als er onvoldoende sediment via de inlaat van de geul wordt aangevoerd en er sediment honger in de nevengeul optreedt. De samenstelling van het beddingsubstraat leent zich goed voor verticale erosie en ondanks dat de nevengeul meer dan tweemaal zo lang wordt in vergelijking met de bestaande nevengeul, is het beddingverhang van de verlengde nevengeul met $0.63 \mathrm{~m} / \mathrm{km}$ nog relatief groot.

De aanleg van de nevengeul leidt naar verwachting in deeltraject A lokaal binnen de dalvlakte tot een grondwaterstanddaling. De GLG volgt in grote lijnen de drainagebasis, hetzij de Vecht, hetzij de restgeul. Omdat in de verlengde nevengeul het peil aanzienlijk lager zal liggen dan in de restgeul zal de GLG, maar ook de GHG, in de omgeving van de nevengeul sterk dalen. Dat effect zal bij het inlaatwerk niet of nauwelijks aanwezig zijn en toenemen met de afstand. Op basis van deze studie kunnen hier geen kwantitatieve uitspraken over gedaan worden.

In deelgebied $\mathrm{B}$ ligt de bedding parallel aan de Vecht. De ontwerpbedding van de nevengeul ligt in dit tracé hoofdzakelijk in zandige Vechtafzettingen, met uitzondering van een smalle zone in het midden van het deelgebied waar de nevengeul een restgeul van de Vecht kruist die is opgevuld met slappe klei en veen. Van de oevers van de nevengeul bestaat de bovenste 0,5-1,2 m uit klei. Op de overgang van deelgebied $B$ naar $C$ snijdt de bedding een pakket grof rivierzand aan. Het peilverschil tussen de Vecht en de nevengeul bedraagt hier ca. 0,80m. Vanuit de Vecht kan door de (grof)zandige ondergrond rivierkwel optreden naar de nevengeul. Dit zou een destabiliserend effect kunnen hebben op de oevers van de nevengeul, temeer ook omdat hier een afdekkend kleipakket ontbreekt.

In deelgebied $\mathrm{C}$ ligt de ontwerpbedding van de nevengeul in (grof)zandige Vechtafzettingen. De geuloevers bestaan ook hier gedeeltelijk uit een kleilaag van 0,80 cm dik. 


\section{$4 \quad$ Landschapsecologische analyse}

\subsection{Fysisch-geografische positie}

De fysisch-geografische positie van het onderzoeksgebied is onderzocht op basis van een landschappelijke bodemkaart, gebaseerd op de geomorfologie en de bodemkaart van het projectgebied en de directe omgeving. Hiervoor zijn de volgende bewerkingen uitgevoerd:

- Vertalen van de detailbodemkaart (Kaart 2 e.v.) naar een gedetailleerde geomorfologische kaart volgens de legenda van 2017 (Maas et al., 2017).;

- Combineren van deze kaart met de geomorfologische kaart van Nederland (www.pdokviewer.nl);

- Combineren van de gedetailleerde bodemkaart van het projectgebied met bestaande bodemkaarten van de omgeving daarbuiten:

- Ten noorden van de Vecht, binnen het winterbed de bodemkaart (1:10.000) van de ruiverkaveling Dedemsvaart (Woperijs \& Rutte, 1971);

- Ten zuiden van de Vecht en ten noorden ervan buiten het winterbed de Bodemkaart van Nederland (1: 50.000; Booij, 1989).

- Op basis van de combinatie van geomorfologie en bodem is een landschappelijke bodemkaart afgeleid volgens de landschapsecologische indeling van de Landschapsleutel (Kemmers et al., 2011; Van Delft et al., 2015). Dit is een hiërarchische indeling op vier niveaus (Fysisch-Geografische regio's, FG-secties, FG-series en FG-typen. Voor het zuidelijke deel van het studiegebied (deelgebied A) en omgeving zijn de Fysisch-Geografische eenheden op het tweede en derde niveau (FysischGeografische sectie en FG-series) weergegeven in Figuur 4.1. In Tabel 4.1 worden de oppervlakten van deze eenheden gegeven.

- Met de landschappelijke bodemkaart beoordelen van potenties en realisatiekansen voor de habitattypen (zie § $4.2 \mathrm{t} / \mathrm{m} \mathrm{4.5)}$ ).

Tabel 4.1 Oppervlakte van FG-typen per FG-serie binnen het studiegebied.

\begin{tabular}{|c|c|c|c|c|c|c|c|}
\hline \multirow[b]{2}{*}{ Fysisch-Geografische typen } & \multicolumn{7}{|c|}{ Fysisch-Geografische typen (zie Figuur 4.1) } \\
\hline & PS012 & PS013 & PS014 & PS016 & PS031C V & w & Totaal \\
\hline HzDV Vochtige dekzandlaagten & 1.595 & 0.042 & & & & & 1.638 \\
\hline RiZD Rivierduinen (RiTS) en Landduinen (HzSD) & & & & & 3.262 & & 3.262 \\
\hline RiZW Oeverwallen (HzBW) & & 5.442 & 1.843 & & & & 7.285 \\
\hline RiZN Natte en verdroogde beek- of rivierdalen ( $\mathrm{HzBN}$ ) & 1.662 & 6.936 & & & & & 8.598 \\
\hline RiZV Benedenlopen en lemige vlakten (HzBV) & & & 3.335 & & & & 3.335 \\
\hline RiZR (voormalige) bedding ( $\mathrm{HzBL}$ ) & & 0.984 & 2.092 & 0.186 & & & 3.262 \\
\hline W & & & & & & 0.829 & 0.829 \\
\hline Eindtotaal & 3.258 & 13.404 & 7.270 & 0.186 & 3.262 & 0.829 & 28.209 \\
\hline
\end{tabular}

De flanken van het Vechtdal vallen nog onder de Fysisch-Geografische sectie 'Dekzandgebieden' (HzD) en de FG-serie 'Vochtige dekzandlaagten' (HzDV). Het dal zelf wordt gerekend bij FG-sectie 'Ingesneden rivieren zonder terrassen' (RiZ). Op basis van geomorfologie en bodem worden daarbinnen vier verschillende FG-series onderscheiden (zie Tabel 4.1 en Figuur 4.1). 


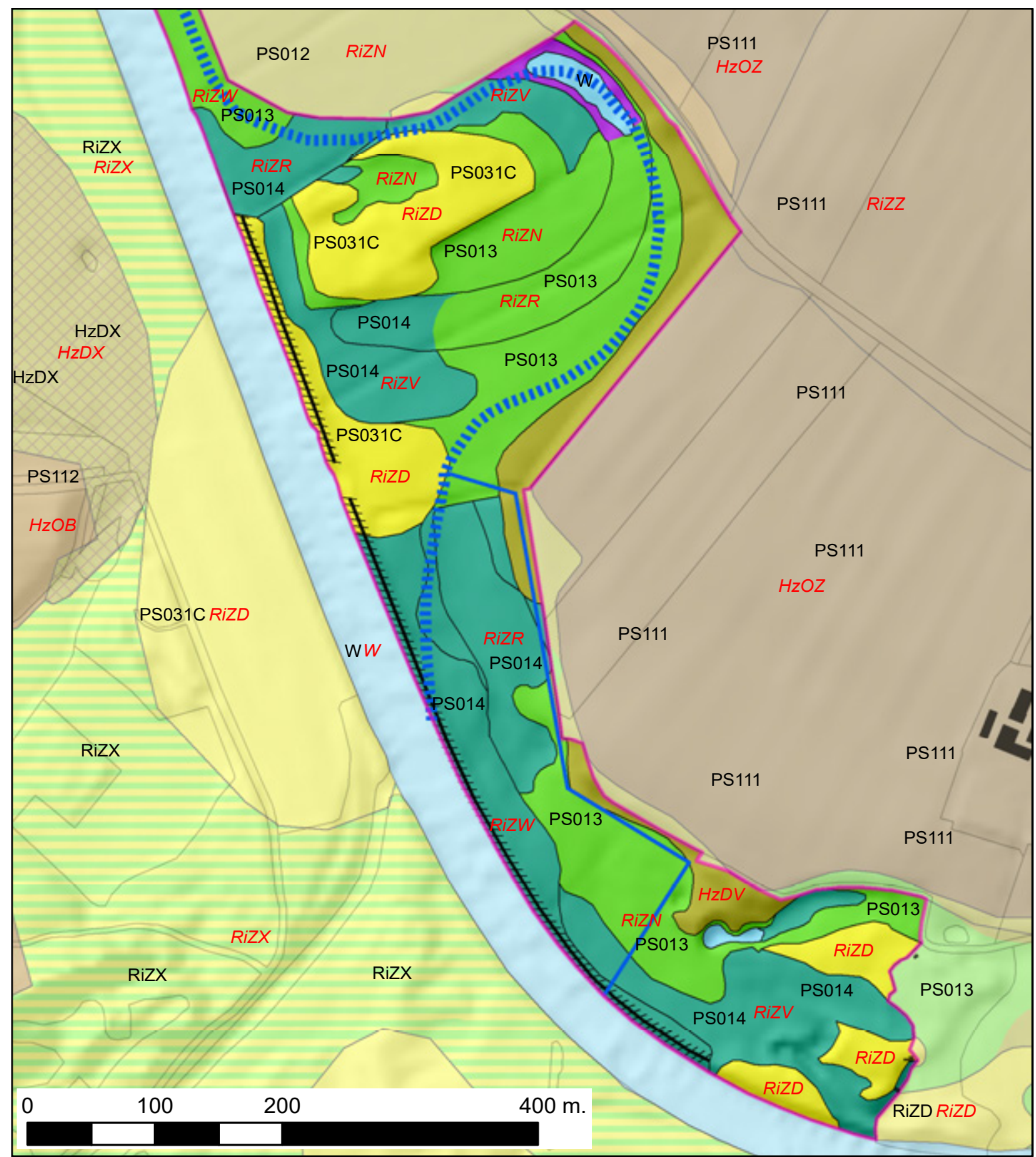

Landschappelijke Bodemkaart (FG-Typen)

\section{Fysich-GeografischType}

PS012 Minerotrofe zandgronden met lateraal toestromend zacht grondwater

PS013 Lithotrofe zandgrond gevoed door zwakke kwel

PS014 Beek- of rivierkleien gevoed door lokale zwakke kwel

PS016 Lithotrofe moerige grond op zand met sterke kwel

PS031C Rivierduinen, zandige oeverwallen en pleistocene zandgronden (kalkarm)
PS111 Hoge zandgronden met een zwart bouwlanddek

PS112 Hoge zandgronden met een bruin bouwlanddek

\section{Niet in te delen}

88 HzDX Dekzandgebieden, nader te bepalen RiZD Rivierduinen (RiTS) en Landduinen (HzSD)

RiZX Nader te bepalen

\section{Overig}

W Water
$\square$ Grenzen FG-series

Figuur 4.1 Landschappelijke bodemkaart van het zuidelijke deel van het projectgebied. De FysischGeografische typen zijn met kleuren aangegeven, de FG-series waarbinnen zij voorkomen met zwarte lijnen en rode codes (zie Tabel 4.2 voor de namen). 


\subsection{Potentiële vegetatieontwikkeling}

Of, en waar, de in § 4.1 genoemde doeltypen (Habitattypen of Beheertypen) tot ontwikkeling kunnen komen, hangt in de eerste plaats af van de landschapsecologische positie zoals weergegeven in de landschappelijke bodemkaart (Figuur 4.1). Dit hebben wij bepaald op basis van de potentiële vegetaties die in de Landschapsleutel gekoppeld worden aan de FG-eenheden (zie Bijlage 3) en de kenmerkende plantengemeenschappen voor de habitattypen (Bijlage 4). De mate waarin deze overeenkomen, bepaalt de kans dat de vegetatieontwikkeling in de richting gaat van een van deze habitattypen. Dit drukken wij uit in de 'affiniteitsindex' van 0 tot 1 . Hoe we deze bepaald hebben en hoe de vergelijking van de huidige situatie met de abiotische randvoorwaarden van de habitattypen is uitgevoerd, wordt besproken in Bijlage 5. In Tabel 4.2 is de affiniteitsindex voor de habitattypen gegeven bij elke FG-eenheid. Hieruit volgt de meest waarschijnlijke vegetatieontwikkeling bij een beheer als korte vegetatie en bij bosontwikkeling in Figuur 4.2 en 4.3. Of de vegetatieontwikkeling ook in die richting gaat, hangt af van de huidige en toekomstige standplaatseigenschappen (Vocht, Zuurgraad, Voedselrijkdom, Overstromingsregime). Op de realisatiekansen en knelpunten wordt ingegaan in $\S 4.3$ en 4.5 .

Tabel 4.2 Fysisch-Geografische eenheden (FG-serie \& FG-type) met de mate waarin de habitattypen passen bij deze eenheden. De hoogste affiniteitswaarden zijn vetgedrukt (affiniteitsindex, zie Bijlage 5).

\begin{tabular}{|c|c|c|c|c|c|c|c|}
\hline FG-Eenheid & Niveau & H4010A & H6120V & H6410 & H7140AV & H91EOC & Opp (ha) \\
\hline HzDV_PS012 & $\mathrm{S}$ & 0.26 & 0 & 0 & 0.17 & 0 & 1.6 \\
\hline RiZN_PS012 & $\mathrm{S}$ & 0.26 & 0 & 0.06 & 0.17 & 0 & 1.66 \\
\hline RiZN_PS013 & $\mathrm{S}$ & 0.05 & 0 & 0.22 & 0.08 & 0.39 & 6.94 \\
\hline RiZR_PS013 & $\mathrm{S}$ & 0.05 & 0 & 0.22 & 0.08 & 0.39 & 0.98 \\
\hline RiZR_PS014 & $\mathrm{S}$ & 0.05 & 0 & 0.23 & 0.08 & 0.1 & 2.09 \\
\hline RiZV_PS014 & $\mathrm{S}$ & 0.05 & 0 & 0.23 & 0.08 & 0.1 & 3.34 \\
\hline RiZW_PS014 & $\mathrm{S}$ & 0.05 & 0 & 0.23 & 0.08 & 0.1 & 1.84 \\
\hline RiZR_PS016 & $\mathrm{S}$ & 0.05 & 0 & 0.28 & 0.56 & 0.38 & 0.19 \\
\hline
\end{tabular}

Toelichting bij de coderingen:

\section{Habitattypen}

- H4010A Vochtige heiden (hogere zandgronden) op de drogere dalflanken

- H6120V Stroomdalgraslanden op zandige oeverwallen en kronkelwaarden

- H6410 Blauwgrasland in de delen met vochtig grasland

- H7140AV Overgangs- en trilvenen in oude meanders

- H91E0C Bossen op alluviale grond met Alnus glutinosa en Fraxinus excelsior

\section{FG-Eenheid}

- PS012 Minotrofe zandgronden met lateraal toestromend zacht grondwater

- PS013 Lithotrofe zandgrond gevoed door zwakke kwel

- PS014 Beek of rivierkleien gevoed door lokale zwakke kwel

- PS016 Lithotrofe moerige grond op zand met sterke kwel

- PS031C Rivierduinen, zandige oeverwallen en pleistocene zandgronden (kalkarm) 


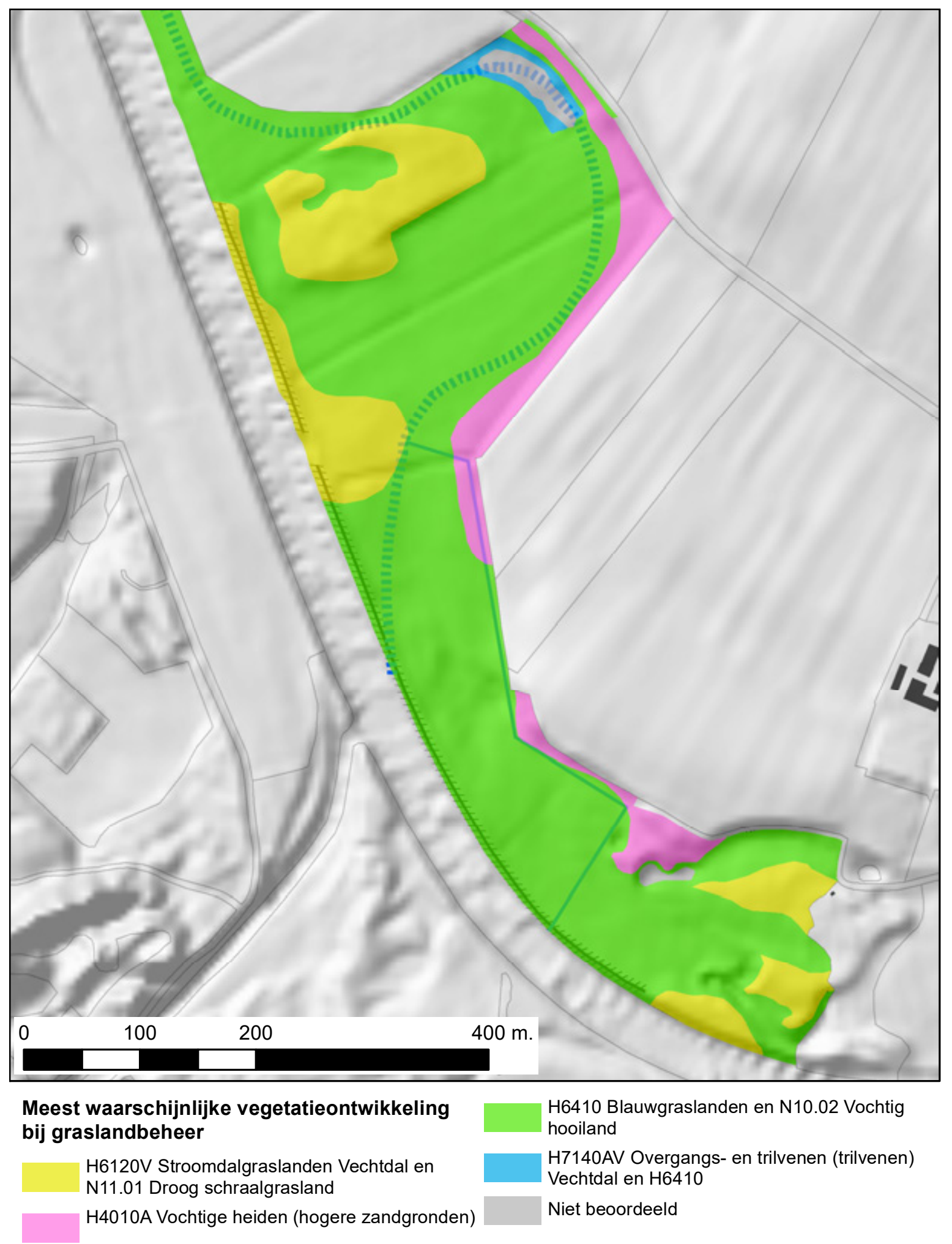

Figuur 4.2 De meest waarschijnlijke vegetatieontwikkeling bij graslandbeheer, afgeleid van de overeenkomst tussen de kenmerkende plantengemeenschappen van de habitattypen en de potentiële vegetaties bij de FG-eenheden. In hoeverre deze ontwikkeling plaatsvindt, hangt af van de abiotische condities in de huidige situatie en na inrichting.

Op de hogere zandige oeverwallen en kronkelwaardruggen lijkt ontwikkeling van stroomdalgrasland mogelijk, met overgangen naar droog schraalgrasland. De lagere delen lijken vooral geschikt voor blauwgrasland met overgangen naar vochtig hooiland. De zandige flanken van het Vechtdal geven eerder een ontwikkeling richting vochtige heide te zien. 


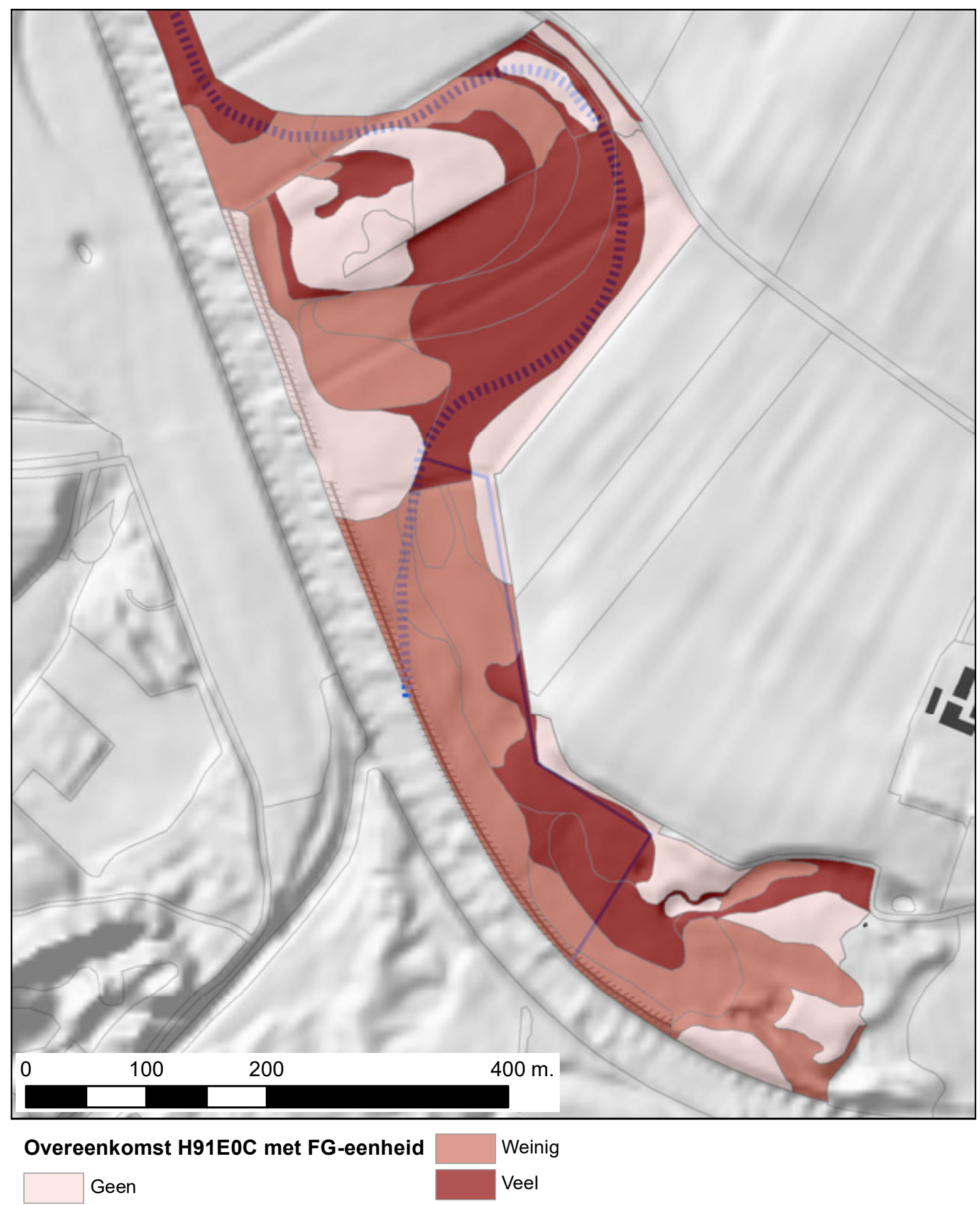

Figuur 4.3 De meest waarschijnlijke vegetatieontwikkeling bij bosontwikkeling (in dit geval alleen H91E0C), afgeleid van de overeenkomst tussen de kenmerkende plantengemeenschappen van de habitattypen en de potentiële vegetaties bij de FG-eenheden. De intensiteit van de kleur geeft de mate van overeenkomst aan. In hoeverre deze ontwikkeling plaatsvindt, hangt af van de abiotische condities in de huidige situatie en na inrichting.

Het geschiktst voor H91E0C 'Vochtige alluviale bossen (beekbegeleidende bossen)' zijn de laagstgelegen, kwelgevoede FG-eenheden PS0013 'Lithotrofe zandgrond gevoed door zwakke kwel' en PS016, 'Lithotrofe moerige grond op zand met sterke kwel' met een zandige of venige bovengrond. Bij de kleibovengronden van PS014 'Beek- of rivierkleien gevoed door lokale zwakke kwel' is de overeenkomst minder groot. 


\subsection{Advies moerassige laagte}

Het plan voorziet in de aanleg van een moerassige laagte als paaiplaats voor vissen (zie Figuur 1.1). Hiervoor zal een deel afgegraven moeten worden om voldoende natte omstandigheden te creëren. Deze laagte zal in elk geval tot ver in het voorjaar watervoerend moeten zijn, maar mag daarna droogvallen. Voor het studiegebied betekent dat dat de natste delen met grondwatertrap wIa en (w)IIa in aanmerking komen. Het zoekgebied in Figuur 1.1 komt in grote lijnen overeen met grondwatertrap IIa (Figuur 2.11). Boring 2032 in dit vlak heeft GHG op $5 \mathrm{~cm}-\mathrm{mv}$. en GLG op $70 \mathrm{~cm}-\mathrm{mv}$. Afgraven van een deel van deze laagte met een wisselende diepte van 20 tot maximaal ca. $50 \mathrm{~cm}-\mathrm{mv}$. lijkt een goede uitgangsituatie te geven waarin het paaien kan plaatsvinden en de larven kunnen opgroeien. De laagte ligt binnen het bereik van inundatiehoogten die jaarlijks te verwachten zijn.

\subsection{Huidige situatie}

\section{Realisatiekansen}

Voor de habitattypen die op basis van hun overeenkomst met de FG-eenheden het waarschijnlijkst zijn, hebben wij vergeleken in hoeverre de huidige abiotische omstandigheden overeenkomen met de abiotische randvoorwaarden van de habitattypen (zie Bijlage 5 en Bijlage 6). De grondwaterstanden zijn beschreven in $\S 2.7$ en de zuurgraad en kwel in $\S 2.9$ en 2.10. De overstromingsfrequentie ( $\S 2.8$ ) is apart beoordeeld. In Figuur 4.4 en 4.5 zijn de realisatiekansen op basis van grondwaterstanden en zuurgraad bepaald voor korte vegetaties en bosvegetaties. De droogste koppen van de kronkelwaardruggen lijken geschikt voor stroomdalgrasland (H6120V), de laagste delen voor Blauwgraslanden (H6410). De kansen voor H91E0C 'Vochtige alluviale bossen (beekbegeleidende bossen)' lijken beperkt tot de restgeul en in mindere mate de laagste delen van de voormalige beddingen. De belangrijkste knelpunten worden getoond in Figuur 4.6 en 4.7. 


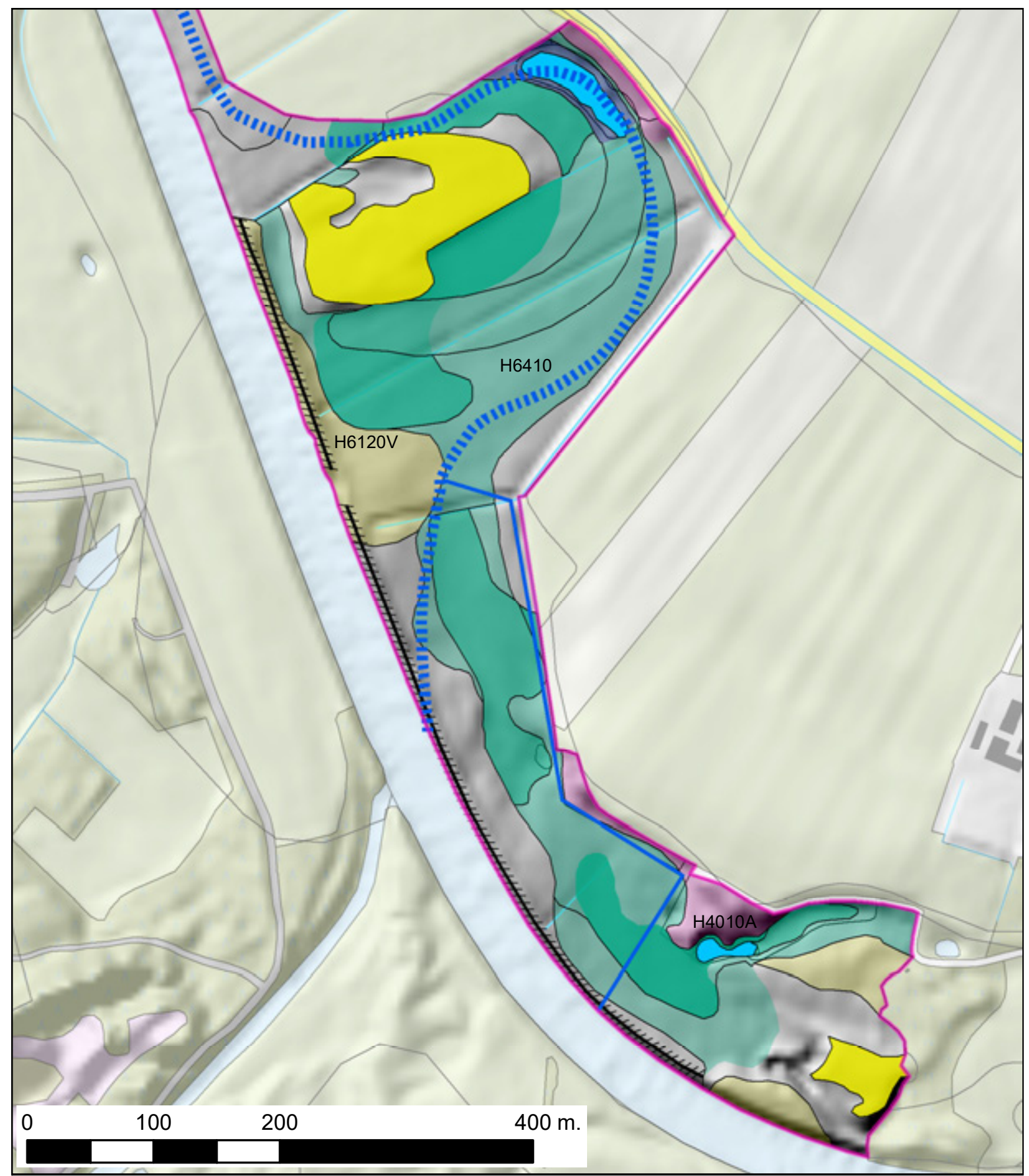

\section{Realisatiekansen korte vegetaties}

H6120V Stroomdalgraslanden Vechtdal H4010A Vochtige heiden (hogere zandgronden)

H6410 Blauwgraslanden

H7140AV Overgangs- en trilvenen (trilvenen) Niet beoordeeld

Figuur 4.4 Realisatiekansen voor habitattypen van korte vegetaties, gebaseerd op de affiniteitsindex, huidige hydrologie en zuurgraad. De intensiteit van de kleur is een indicatie voor de realisatiekans: naarmate deze groter is, is de kleur intenser. 


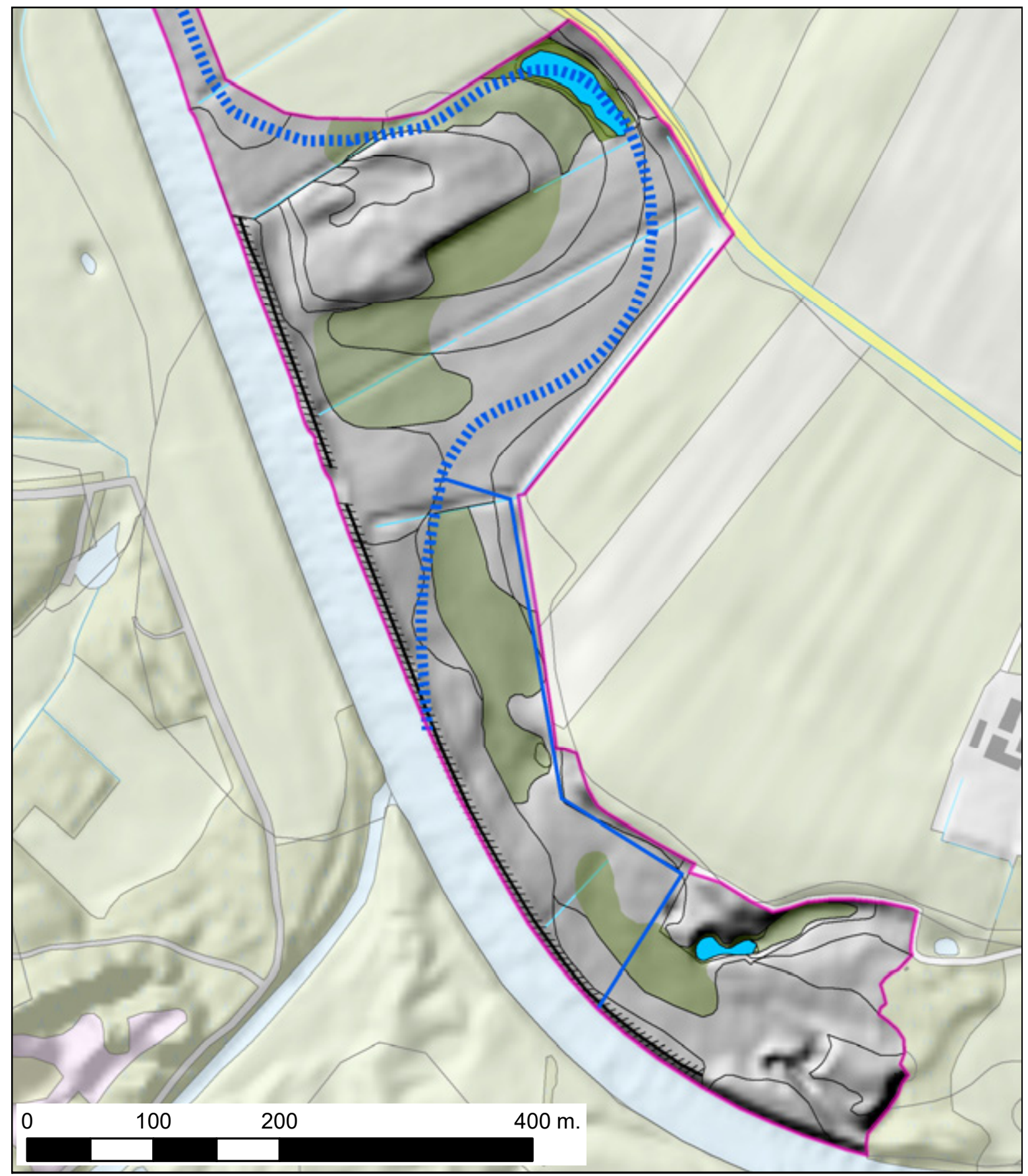

\section{Realisatiekansen bosvegetaties}

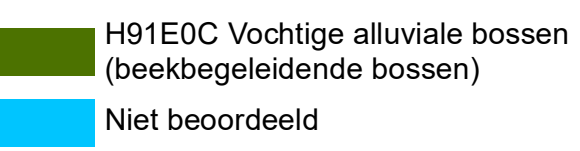

Figuur 4.5 Realisatiekansen voor habitattypen van bosvegetaties (hier allen H91E0C), gebaseerd op de affiniteitsindex, huidige hydrologie en zuurgraad. De intensiteit van de kleur is een indicatie voor de realisatiekans: naarmate deze groter is, is de kleur intenser.

\section{Knelpuntenanalyse H6120V Stroomdalgraslanden Vechtdal}

Uit de berekende indexen voor de abiotische randvoorwaarden per FG-eenheid blijkt dat voor stroomdalgrasland vooral de GVG beperkend is, omdat deze te ondiep is (zie Bijlage 6). In Figuur 4.6 is dit ruimtelijk weergegeven. Alleen in de hoogste koppen van de kronkelwaardruggen voldoet de GVG optimaal voor stroomdalgrasland, de lagere oeverwallen zijn minder geschikt, omdat de GVG hier in delen te ondiep is. Het gedeelte van deelgebied $A$ dat te nat is (index -1), valt grotendeels samen met FG-eenheden die niet geschikt zijn voor dit habitattype (zie 4.2). Uit vergelijking met Figuur 2.12 kan 
opgemaakt worden dat in de hoogste delen van de kronkelwaardruggen de inundatiefrequentie te laag is en dat vooral de delen op de overgang naar de lagere delen het kansrijkst zijn voor ontwikkeling naar stroomdalgraslanden. Dit moet niet te absoluut gezien worden, omdat overstromingen onregelmatig kunnen optreden. Het meest logisch is dat er allerlei overgangen zullen optreden van stroomdalgraslanden naar droog schraalgrasland en heide aan de droge kant en heischraal grasland en blauwgrasland aan de natte kant. Dat is ook het geval in bestaande natuurgebieden.

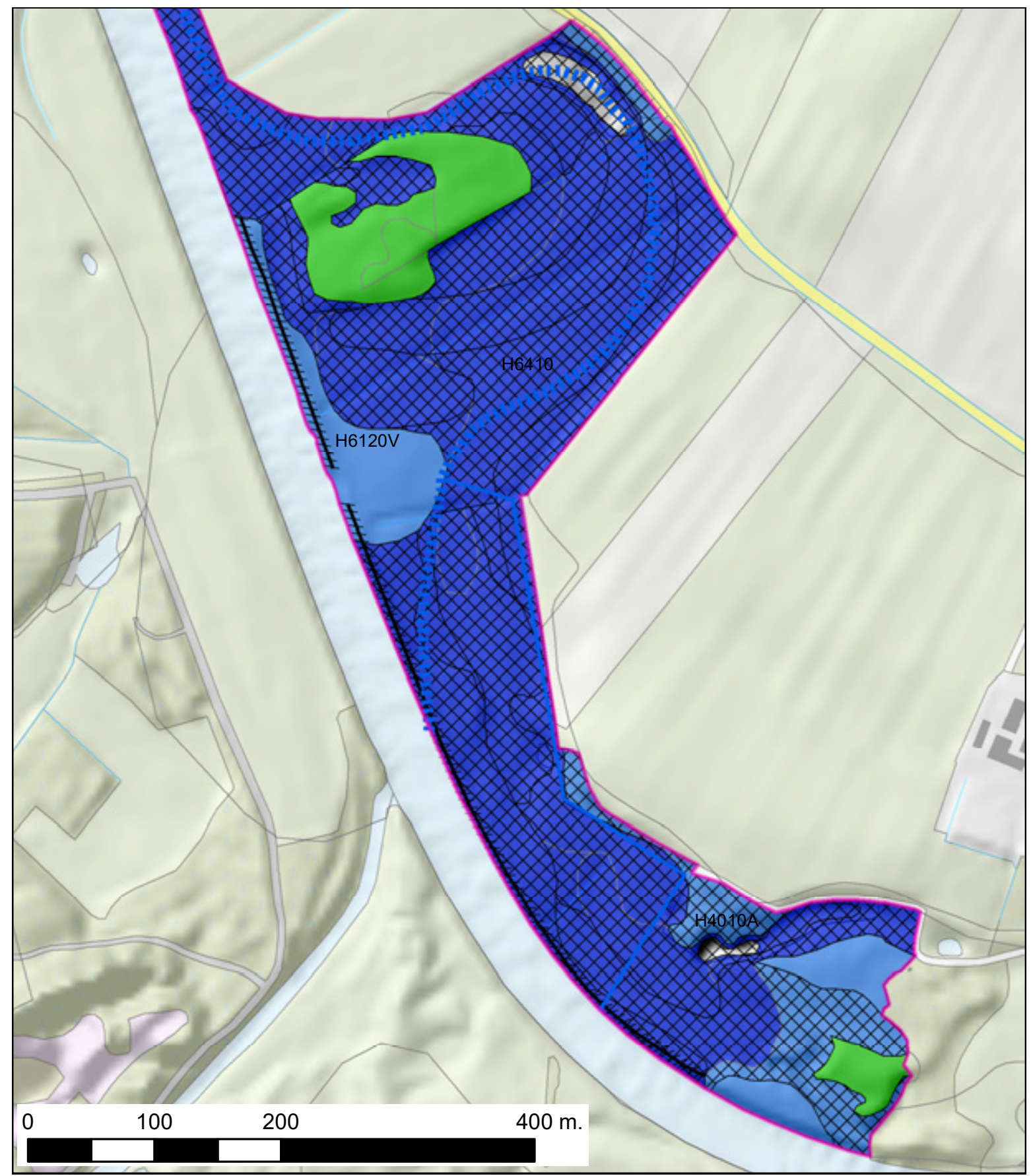

\section{Geschiktheid GVG voor H6120V FG-eenheid ongeschikt voor H6120V}

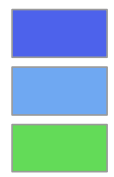

-1 Ongeschikt, te nat

FG-eenheid ongeschikt voor H6120V

$-1--0.75$ Weinig geschikt

$-0.25-0$ Gechikt

Figuur 4.6 Geschiktheid van de GVG in de huidige situatie voor H6120V 'Stroomdalgraslanden Vechtdal'. 
In de lagere delen van de oeverwallen en kronkelwaardruggen die op basis van GVG en overstromingsfrequentie als weinig geschikt geclassificeerd zijn, blijkt ook de zuurgraad niet optimaal te zijn. De pH is hier wat aan de hoge kant (Bijlage 6).

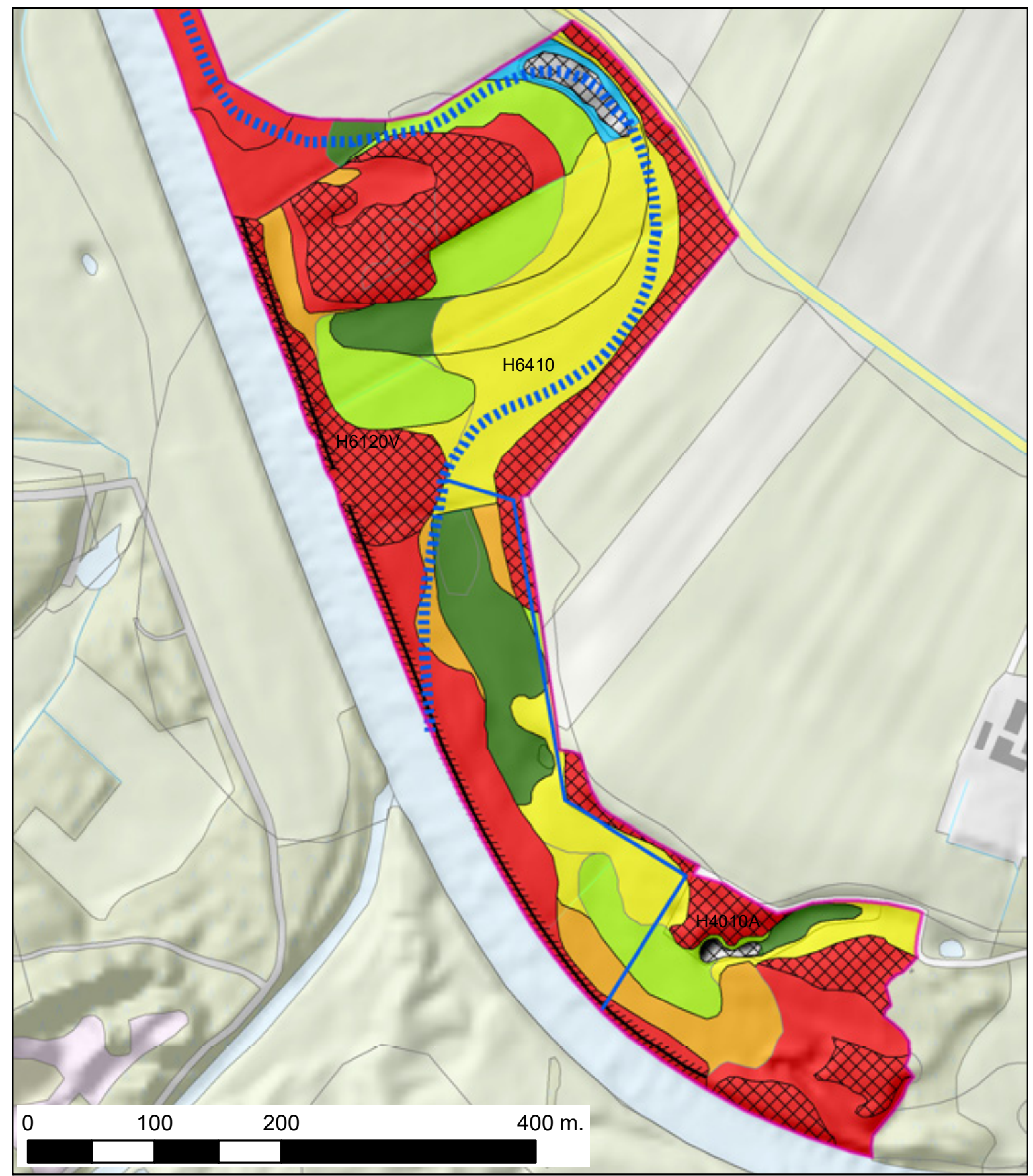

\section{Geschiktheid GVG voor H6410}

\section{FG-eenheid ongeschikt voor H6410}

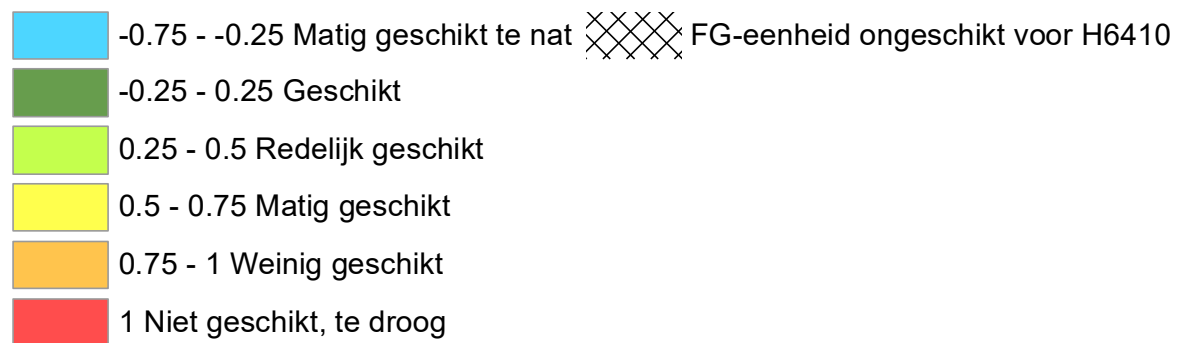

Figuur 4.7 Geschiktheid van de GVG in de huidige situatie voor H6410 'Blauwgraslanden'. 
Ook voor blauwgraslanden blijkt dat de GVG de beperkende factor is, maar dan omdat deze in een aantal gevallen te diep is (Figuur 4.7, Bijlage 6). In een aantal situaties geldt dat ook voor droogtestress, maar dat zijn steeds fysiotopen waarbij de index voor GVG $=1$ en die om die reden al als ongeschikt zijn aangemerkt. Over het algemeen komt de zuurgraad goed overeen met de abiotische randvoorwaarden.

De gebieden die op basis van de GVG als geschikt voor blauwgrasland/overstromingsgrasland uit de analyse naar voren komen, zijn ook de gebieden die jaarlijks en mogelijk ook tijdens het groeiseizoen inunderen (zie Figuur 4.7).

\subsection{Na inrichting}

Om het effect van de inrichting op de realisatiekansen voor de habitattypen te kunnen beoordelen hebben wij alleen gekeken naar het directe effect op de ontwatering door het lagere peil in de verlengde nevengeul en de betere bereikbaarheid voor inundatiewater door het doorbreken van de huidige kade. Daarnaast is gekeken naar het effect van het voorgenomen herstel van een rivierduin tot 6,5 m +NAP. Over het effect van andere maatregelen in de Vecht en de precieze doorwerking op grondwaterstanden en inundaties is nog onvoldoende bekend.

Binnen deelgebied A zullen de grondwaterstanden dalen als gevolg van het lagere peil in de verlengde nevengeul. In het zuiden, bij de inlaat, zal dit effect nihil zijn, stroomafwaarts neemt de verlaging langs de geul toe tot $80 \mathrm{~cm}$ bij de overgang naar deelgebied B. Dat betekent een forse verdroging in het noordelijke deel van dit deelgebied. Voor stroomdalgraslanden betekent dat dat deze wat lager op de gradiënt tot ontwikkeling zullen komen en dat wellicht ook de oeverwal ten noordwesten van de inlaat deels geschikt wordt voor dit habitattype. De hoogste kop van de kronkelwaardrug zal hiermee zeker te droog worden. Dat zal nog sterker het geval zijn wanneer dit deel opgehoogd wordt tot 6,5 m +NAP, waardoor de gehele hoogte te droog en ver buiten het bereik van de verwachte inundaties zal komen. Deze ophoging raden wij dan ook af.

Een sterk negatief effect van de grondwaterstanddaling is te verwachten voor de realisatiekansen voor blauwgraslanden of overstromingsvegetaties. Het hele gebied stroomafwaarts van het inlaatwerk zal hiermee ongeschikt worden voor dit habitattype. Ten zuiden van de kronkelwaard kan dit ondervangen worden door de opgevulde voormalige beddingen (code $\mathrm{H}$ op de kaart met vergaven gronden, zie $\S 2.6)$ te herstellen door het opgebrachte materiaal te verwijderen. Omdat in dit eerste deel van de verlengde nevengeul het verdrogingseffect beperkt is, zal hiermee de realisatiekans voor dit habitattype toenemen ten opzichte van de berekende kansen in Figuur 4.4.

Omdat de geplande moerassige laagte (paaiplaats) bovenstrooms van de inlaat komt, is hier geen verdroging te verwachten. Door de inlaat zal de in Figuur 2.12 aangegeven inundatiefrequentie (jaarlijks) wel gehaald worden, wat gunstig is voor de paaiplaats. 


\section{$5 \quad$ Conclusie}

Ten aanzien van de vijf onderzoeksvragen komen we op basis van de LESA tot de volgende conclusies:

\section{Hoe zit het projectgebied fysisch-geografisch in elkaar?}

Het projectgebied ligt in het Vechtdal in het bereik van een afgesneden verlaten meanderbocht van de Vecht. De afsnijding heeft plaatsgevonden voor 1754. De geul is daarna verland en opgevuld met veen en klei. De binnenzijde van de meanderbocht bestaat uit een kronkelwaard met meanderruggen en -geulen. Vermoedelijk is tijdens de ruilverkaveling in de jaren zeventig van de vorige eeuw een deel van de kronkelwaard afgegraven waarmee de restgeul is gedempt. Het perceel is daarna geëgaliseerd. De drainagebasis in de dalvlakte wordt in grote mate bepaald door het peil van de Vecht. Aan de randen van het dal wordt de grondwaterstand beïnvloed door het grondwaterregiem op het terras. In de laagste delen van de dalvlakte treedt kwel aan maaiveld op.

\section{Verwachte invloed van het substraat op de hydro-morfologische ontwikkeling van de nevengeul}

De bedding van de ontwerp nevengeul ligt over vrijwel het gehele tracé in zandige Vechtafzettingen. De oevers van de ontwerp nevengeul liggen in het meest bovenstroomse deel van de geul (deeltraject A), geheel of gedeeltelijk in venig en kleiig substraat. Het cohesieve karakter van de bodem in de oeverzone van de nevengeul heeft hier een stabiliserende werking op potentiële morfologische processen in de geul. Laterale verplaatsing van de geul is op grond van de samenstelling van de bodem in de oeverzone en de relatief geringe breedte-diepteverhouding van de geul in deeltraject $A$ niet of nauwelijks te verwachten; grosso modo zal de nevengeul naar verwachting vrij stabiel in de dalvlakte liggen. De ontwerp nevengeul kan wel verticaal eroderen en als er onvoldoende sediment via de inlaat van de geul wordt aangevoerd, zal de bedding zich kunnen verdiepen. De samenstelling van het beddingsubstraat leent zich goed voor verticale erosie en ook het beddingverhang van de verlengde nevengeul blijft ondanks de verlenging nog relatief groot $(0,63 \mathrm{~m} / \mathrm{km})$.

De ontwerpbedding van de nevengeul ligt in deelgebied $B$ en $C$ eveneens in zandige Vechtafzettingen. Van de oevers van de nevengeul bestaat de bovenste 0,5-1,2 $\mathrm{m}$ uit klei. Op de overgang van deelgebied $B$ naar $C$ snijdt de bedding een pakket grof rivierzand aan. Het peilverschil tussen de Vecht en de nevengeul bedraagt hier ca. 0,80m. Vanuit de Vecht kan door de (grof)zandige ondergrond rivierkwel optreden naar de nevengeul. Deze kwelstroom zou destabiliserend kunnen werken op de oevers van de nevengeul, temeer ook omdat hier een afdekkend kleipakket ontbreekt. De kans op laterale verplaatsing van de geul is ook in deeltrajecten B en C gering. Evenals in deeltraject A is er bij onvoldoende sedimentaanvoer in deeltraject B en C kans op verticale erosie.

De aanleg van de nevengeul leidt naar verwachting vooral in deeltraject A lokaal binnen de dalvlakte tot een grondwaterstanddaling. Omdat in de verlengde nevengeul het peil aanzienlijk lager zal liggen dan in de restgeul zal de GLG, maar ook de GHG, in de omgeving van de nevengeul sterk dalen. Dat effect zal bij het inlaatwerk niet of nauwelijks aanwezig zijn en zal toenemen met de afstand.

\section{Welke locatie is gezien de eisen en randvoorwaarden die eraan worden gesteld geschikt als moerassige laagte annex vispaaiplaats?}

In het studiegebied komt een aantal natte terreindelen voor met grondwatertrap wIa en (w)IIa die hiervoor in aanmerking komen. Het zoekgebied voor en moerassige in Figuur 1.1 valt samen met een laagte met grondwatertrap IIa (Figuur 2.11). Dit vlak heeft een GHG op $5 \mathrm{~cm}-\mathrm{mv}$. en een GLG op 70 $\mathrm{cm}-\mathrm{mv}$. Afgraven van een deel van deze laagte met een wisselende diepte van $20 \mathrm{~cm}$ tot maximaal ca. $50 \mathrm{~cm}$ beneden het huidige maaiveld lijkt een goede uitgangsituatie te geven voor een moeraslaagte waarin het paaien kan plaatsvinden en de larven kunnen opgroeien. Omdat de geplande moerassige laagte (paaiplaats) bovenstrooms van de inlaat komt, is hier geen verdroging te 
verwachten. Door de inlaat zal de in Figuur 2.12 aangegeven inundatiefrequentie (jaarlijks) wel gehaald worden, wat gunstig is voor deze paaiplaats.

\section{Wat betekent de fysisch-geografische positie voor de realisatiekansen van gewenste natuurtypen?}

De droogste koppen van de kronkelwaardruggen lijken geschikt voor stroomdalgrasland (H6120V). Alleen hier is de GVG optimaal voor stroomdalgrasland, de lagere oeverwallen zijn minder geschikt. Op de hoogste delen van de kronkelwaardruggen is echter de inundatiefrequentie te laag. Daaruit volgt dat vooral de delen op de overgang naar de lagere delen van de kronkelwaard het kansrijkst zijn voor ontwikkeling naar stroomdalgraslanden. Het meest logisch is dat er in de kronkelwaard allerlei overgangen zullen optreden van stroomdalgraslanden naar droog schraalgrasland en heide. Alleen de allerlaagste terreindelen met grondwatertrap wIa en (w)IIa zijn geschikt voor blauwgraslanden (H6410). Voor alle andere delen is een te lage GVG de beprekende factor. De kansen voor H91E0C 'Vochtige alluviale bossen (beekbegeleidende bossen)' lijken beperkt tot de restgeul en in mindere mate tot de laagste delen van de voormalige beddingen.

\section{Hoe worden deze realisatiekansen beïnvloed door de voorgestelde inrichting?}

De grondwaterstanden zullen dalen als gevolg van het lagere peil in de verlengde nevengeul. Dat betekent een forse verdroging in het noordelijke deel van dit deelgebied. Voor stroomdalgraslanden betekent dat dat deze wat lager op de gradiënt tot ontwikkeling zullen komen en dat wellicht ook de oeverwal ten noordwesten van de inlaat deels geschikt wordt voor dit habitattype. De hoogste kop van de kronkelwaardrug zal hiermee zeker te droog worden. Dat zal nog sterker het geval zijn wanneer dit deel opgehoogd wordt tot 6,5 m +NAP, waardoor de gehele hoogte te droog en ver buiten het bereik van de verwachte inundaties zal komen. Deze ophoging raden wij dan ook af.

Een sterk negatief effect van de grondwaterstanddaling is te verwachten voor de realisatiekansen voor blauwgraslanden of overstromingsvegetaties. Het hele gebied stroomafwaarts van het inlaatwerk zal hiermee ongeschikt worden voor dit habitattype. Deels kan dit ondervangen worden door de opgevulde voormalige beddingen (code $\mathrm{H}$ op de kaart met vergaven gronden, zie $\S 2.6$ ) te herstellen door het opgebrachte materiaal te verwijderen. Omdat in dit eerste deel van de verlengde nevengeul het verdrogingseffect beperkt is, nemen als gevolg van het afgraven van het opgebrachte materiaal de realisatiekansen voor dit habitattype toe. 


\section{Literatuur}

Arcadis, 2017. Situatie Karshoek/Stegeren; Presentatietekening d.d. 15-9-2017. Arnhem, Arcadis. Booij, A.H., 1989. Bodemkaart van Nederland Schaal 1 : 50 000; Toelichting bij de kaartbladen 22 West en 22 Oost Coevorden. Wageningen, Staring Centrum/Stiboka.

Brouwer, F., Ten Cate, J.A.M. \& Scholten, A., 1992. Bodemgeografisch onderzoek in landinrichtingsgebieden; Bodemvorming, methoden en begrippen. Wageningen, DLO-Staring Centrum. Rapport 157.

De Bakker, H. \& Schelling, J., 1989. Systeem van bodemclassificatie voor Nederland; de hogere niveaus. Wageningen, Pudoc.

Jalink, Mark, Van Delft, Bas \& Leunk, Inke, 2017. Ecohydrologische verkenning Vechtdal OmmenMarienberg. Nieuwegein/Wageningen, KWR Water Research Institute/Wageningen Environmental Research (Alterra). KWR 2016.100.

Jalink, Mark \& Van Delft, Bas, 2017. LESA Overijsselse Vecht Fase 3/4: Veldonderzoek Karshoek en Stegerense Veld. Nieuwegein/Wageningen, KWR Water Research Institute/Wageningen Environmental Research (Alterra). KWR 2017.074.

Kemmers, R. H., Delft, S. P. J. van \& Gaast, J.W.J. van der, 2005. Kwel en Waternood; Ontwikkeling van een methode voor kartering van kwel en de evaluatie van de gevolgen van peilbeheer voor kwelpatronen. Wageningen, Alterra. Alterra-rapport 1034.

Kemmers, R. H., Van Delft, S.P.J., Van Riel, M.C., Hommel, P.W.F.M., Jansen, A.J.M., Klaver, B., Loeb, R., Runhaar, J. \& Smeenge, H., 2011. Landschapsleutel; Leidraad voor natuurontwikkeling. Wageningen, Alterra, onderdeel van Wageningen UR. Alterra-rapport 2140.

Maas, G. en E. van Slobbe, 2017. Projectplan Lumbricus; plan van aanpak Bypass Karshoek Stegeren. WUR, Wageningen.

Maas, Gilbert, Michaël van Buuren \& Bas van Delft, 2018. Verlenging nevengeul Junne door bouwen met natuur. Proefproject Boeiende Beekdalen van het LUMBRICUS programma; fase 1.

Wageningen, WENR. Rapportage in het kader van het Programma Lumbricus Boeiende Beekdalen.

Scheer, van der, J., 2017. Nieuwe meander Junne; hydraulisch ontwerp. Memo Waterschap Vechtstromen.

Ten Cate, J.A.M., Van Holst, A.F., Kleijer, H. \& Stolp, J., 1995. Handleiding bodemgeografisch onderzoek; Richtlijnen en voorschriften; Deel A: Bodem. Wageningen, SC-DLO. Technisch document 19A.

Van Delft, Bas, De Waal, Rein, Kemmers, Rolf, Mekkink, Peter \& Sevink, Jan, 2006. Field guide Humus Forms; Description and classification of humus forms for ecological applications. Wageningen, Alterra.

Van Delft, S. P. J., Maas, G. J. \& De Waal, R.W., 2015. "De Landschapsleutel OnLine." 2015, http://landschapsleutel.wur.nl/. Wageningen, Alterra - Wageningen UR.

Van Delft, S.P.J., De Groot, W.J.M. \& Maas, G. J., 2017. Bodemkartering van een deel van Landgoed Twickel; Kartering bodem en grondwater met beoordeling bosbouwgeschiktheid en natuurpotentie. Wageningen, Wageningen Environmental Research. WEnR-rapport 2857. 114 p. Van der Scheer, Jeroen, 2017. Nieuwe meander Junne; hydraulisch ontwerp. Almelo, Waterschap Vechtstromen. MEMO 18 september 2017.

Vechtstromen, Waterschap, 2016. Natuurlijk Vecht; Natura 2000 Vecht en Beneden Regge; Verkenning Vechtdal Samen Werkt Beter. Definitief 14 oktober 2015. Almelo, Waterschap Vechtstromen. 


\section{Bijlage 1 Landschapsontwikkeling op de kaart}

Kaarten Overijssel http://gisopenbaar.overijssel.nl/viewer/app/atlasvanoverijssel_basis/v1

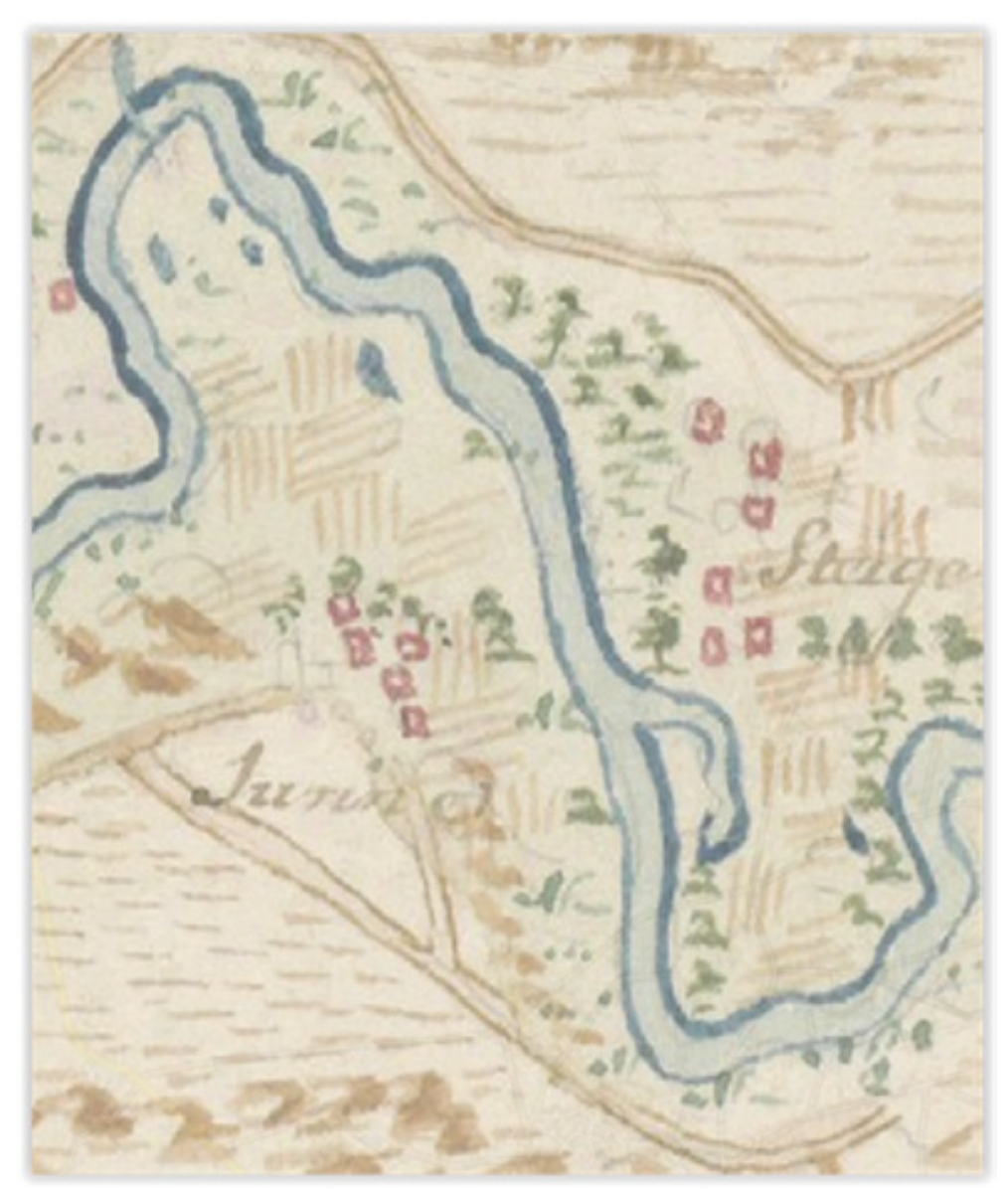

Figuur B1.1 1754 Hattinga (noord) Meander reeds verlaten, de loop tussen Prathoek en meander is recht. 


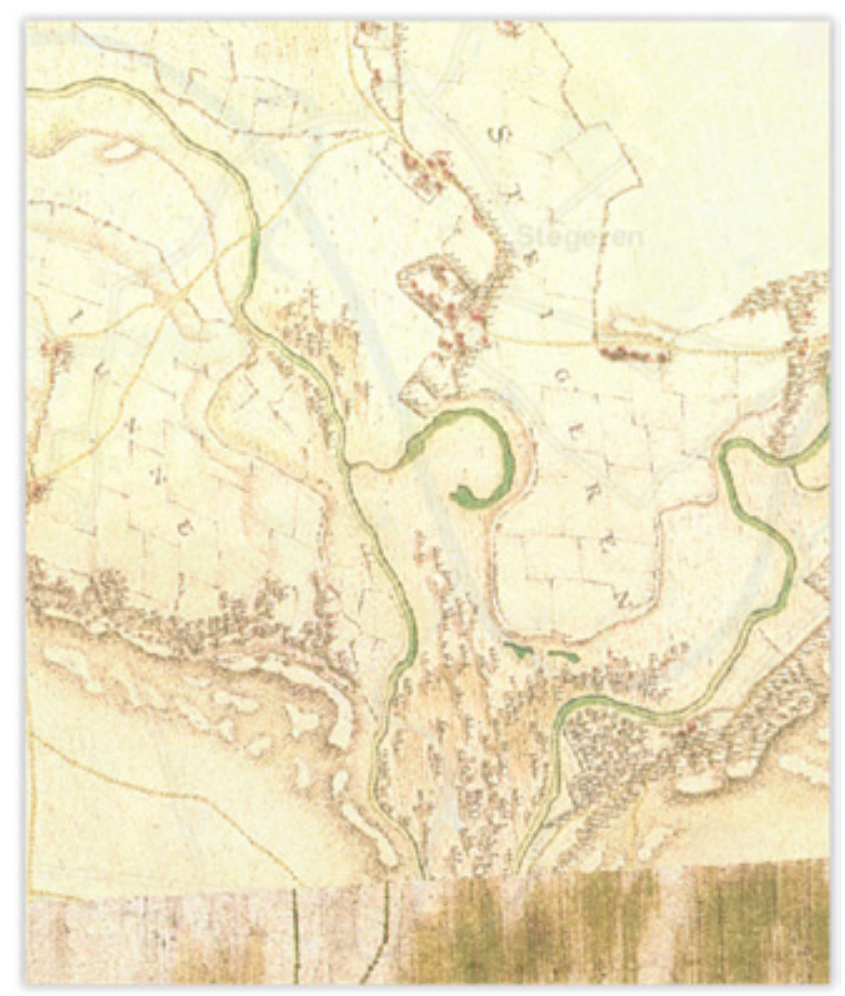

Figuur B1.2 1787 Hottinger Meander reeds verlaten, de loop tussen Prathoek en meander is recht.

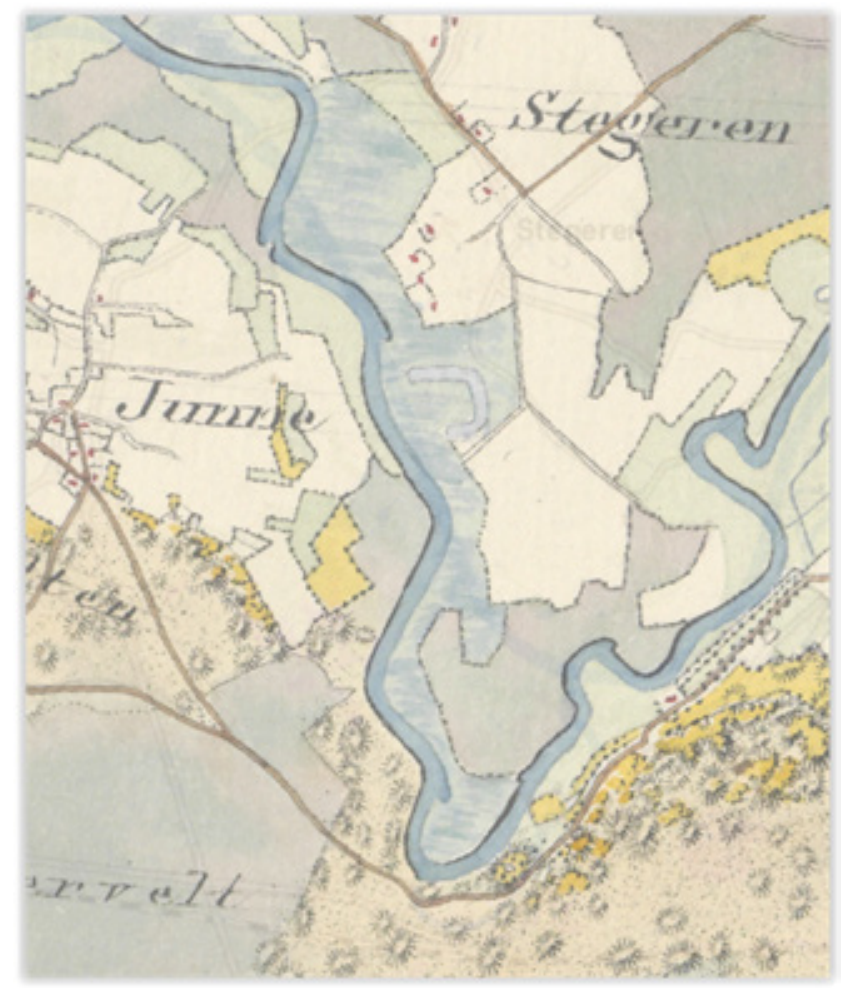

Figuur B1.3 1824 Huguenin kaart. 
Kaarten Topotijdreis http://www.topotijdreis.nl/

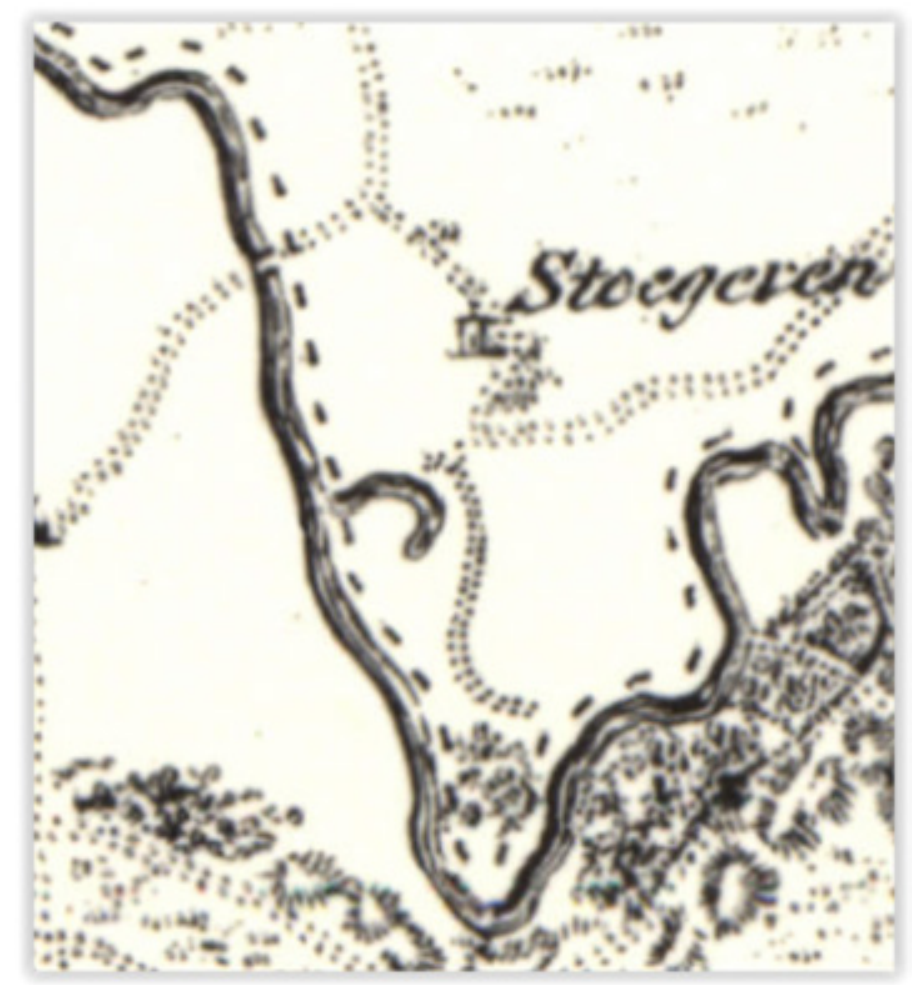

Figuur B1.4 1822 De meander bij de Spijkerweg is al verlaten en deels gedempt/verland.

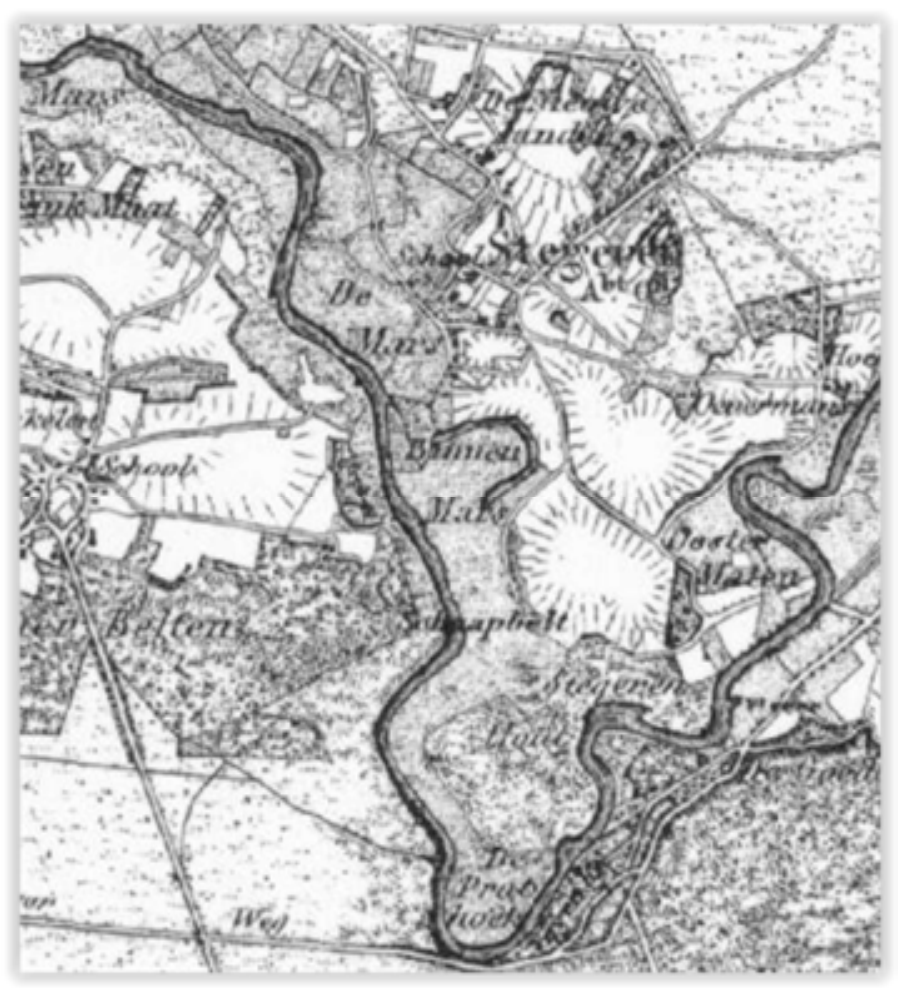

Figuur B1.5 1851 Meander watert via sloot af op Vecht. 


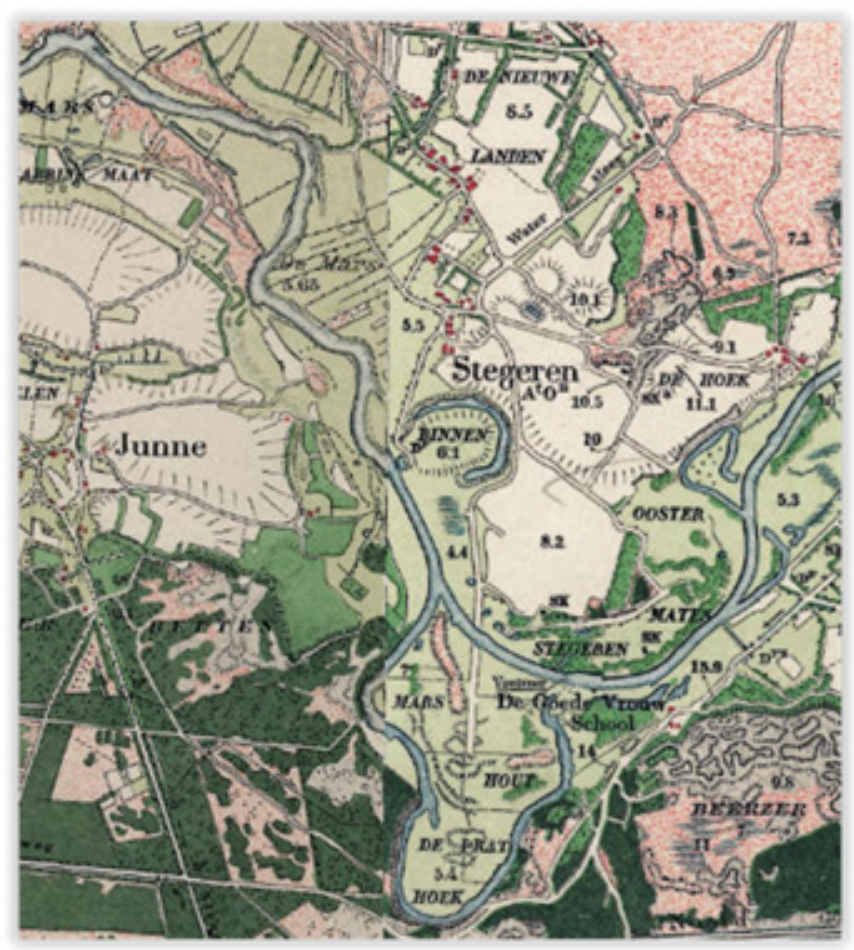

Figuur B1.6 1904 Meander Prathoek afgesneden, ontsluiting graslanden binnen meander via pad vanaf Stegeren. Moerassige laagte zichtbaar waar waarschijnlijk oude loop gelegen heeft tussen Prathoek en meander in loop vóór 1754. Slagenverkaveling hooilanden bij De Mars ten zuiden daarvan niet i.v.m. begrazing?

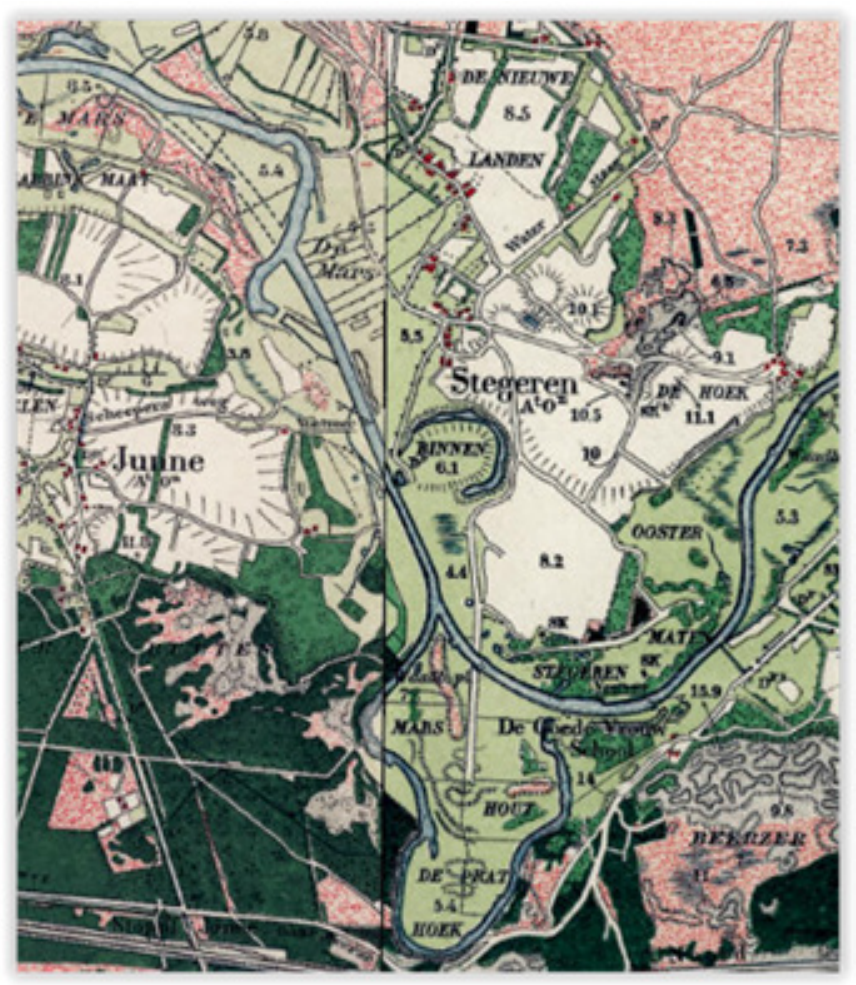

Figuur B1.7 1908 Bocht voorbij meander is nu ook afgesneden. Op de rechteroever is nog een restgeul zichtbaar. Langs de rand van de es ten oosten van de meander loopt weg naar pont voor Prathoek. 


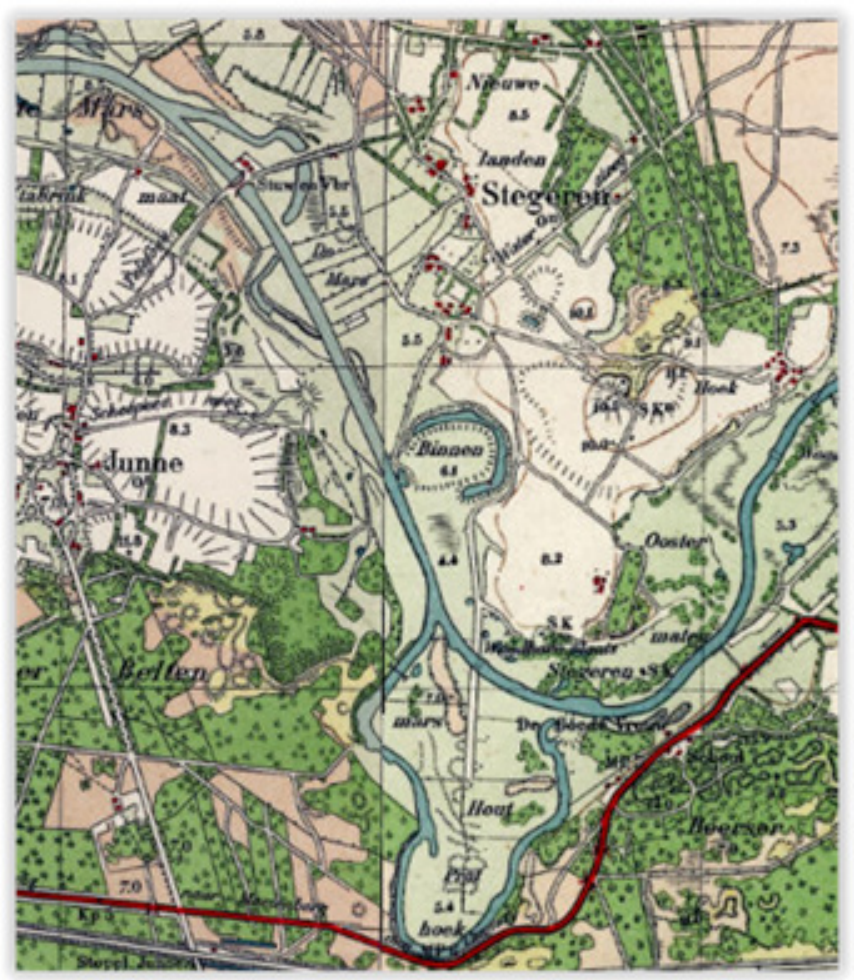

Figuur B1.8 1931 Meander bij Junne afgesneden, stuw bij Junne.
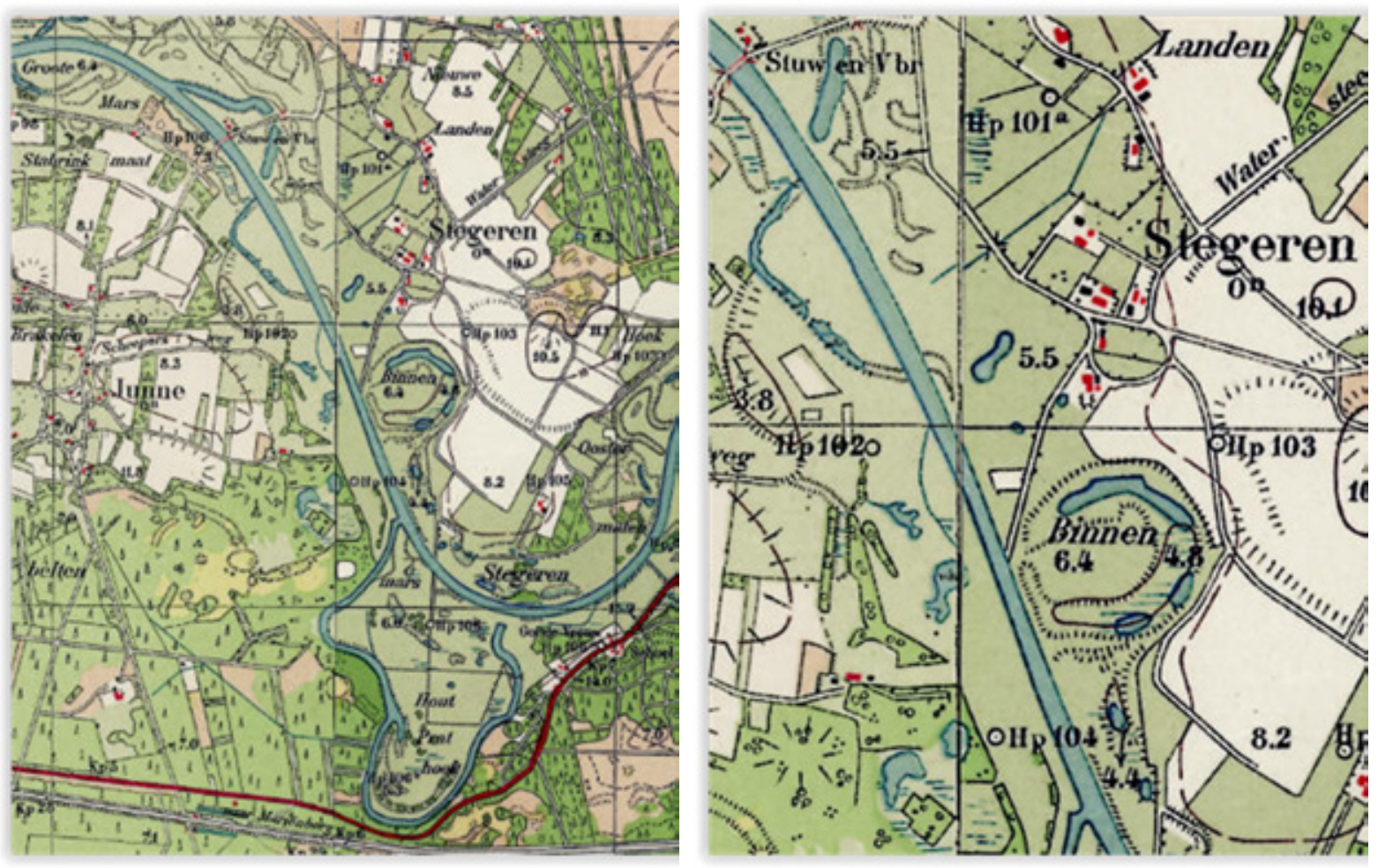

Figuur B1.9 1936 Deel meander bij Spijkerweg gedempt, nog wel zichtbaar. Reliëf rondom meander gedetailleerd aangegeven. Rest meander stroomafwaarts ronder aangegeven dan op oudere kaarten. Slagenverkaveling grotendeels verdwenen. In plaats daarvan veel reliëf aangegeven. 

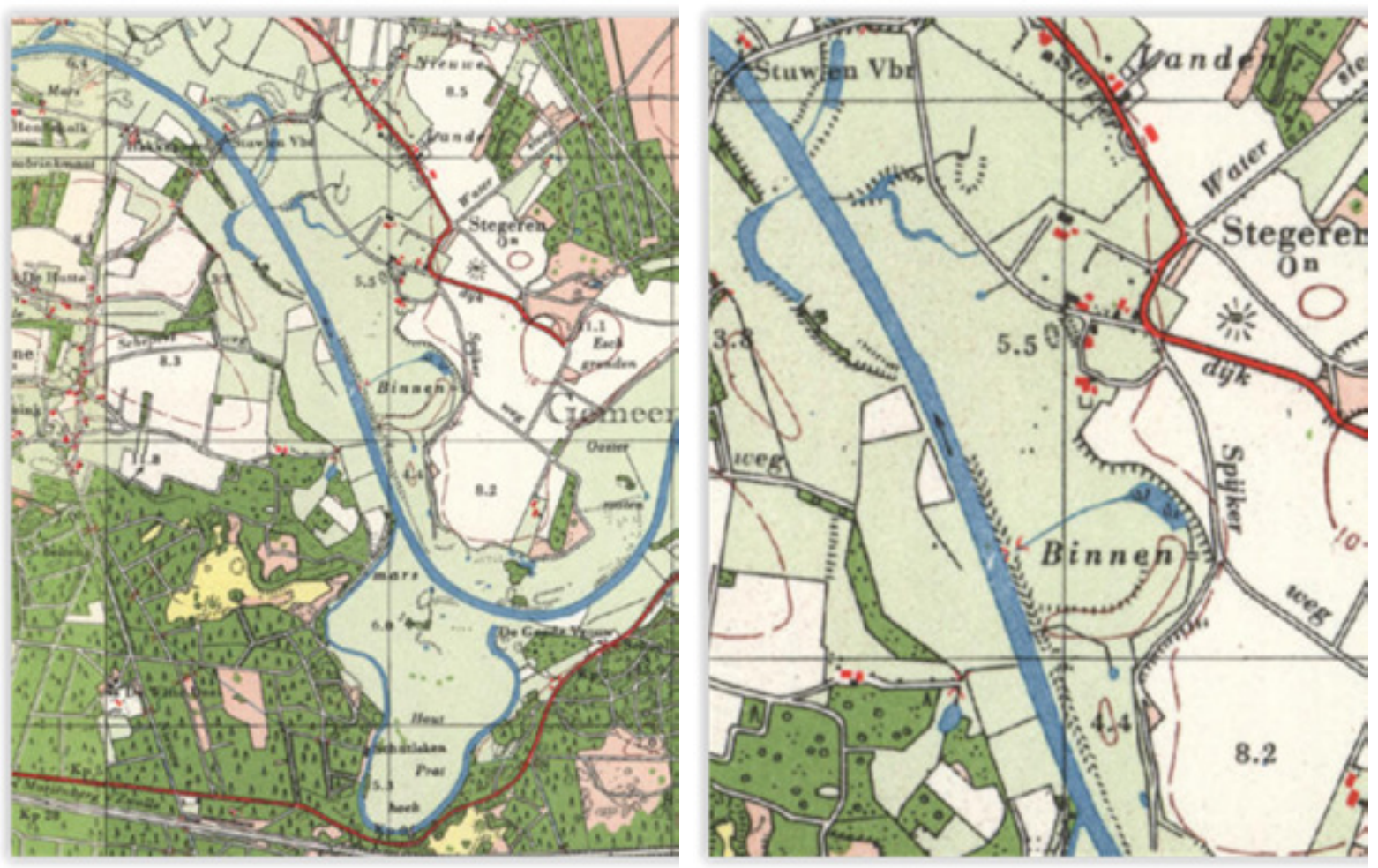

Figuur B1.10 1954 Meander Spijkerweg grotendeels gedempt tot huidige omvang. Ontwatering op de Vecht door duiker. Onts/uiting vanuit Stegeren verdwenen. Langs omgeving meander is voor het eerst kade zichtbaar.
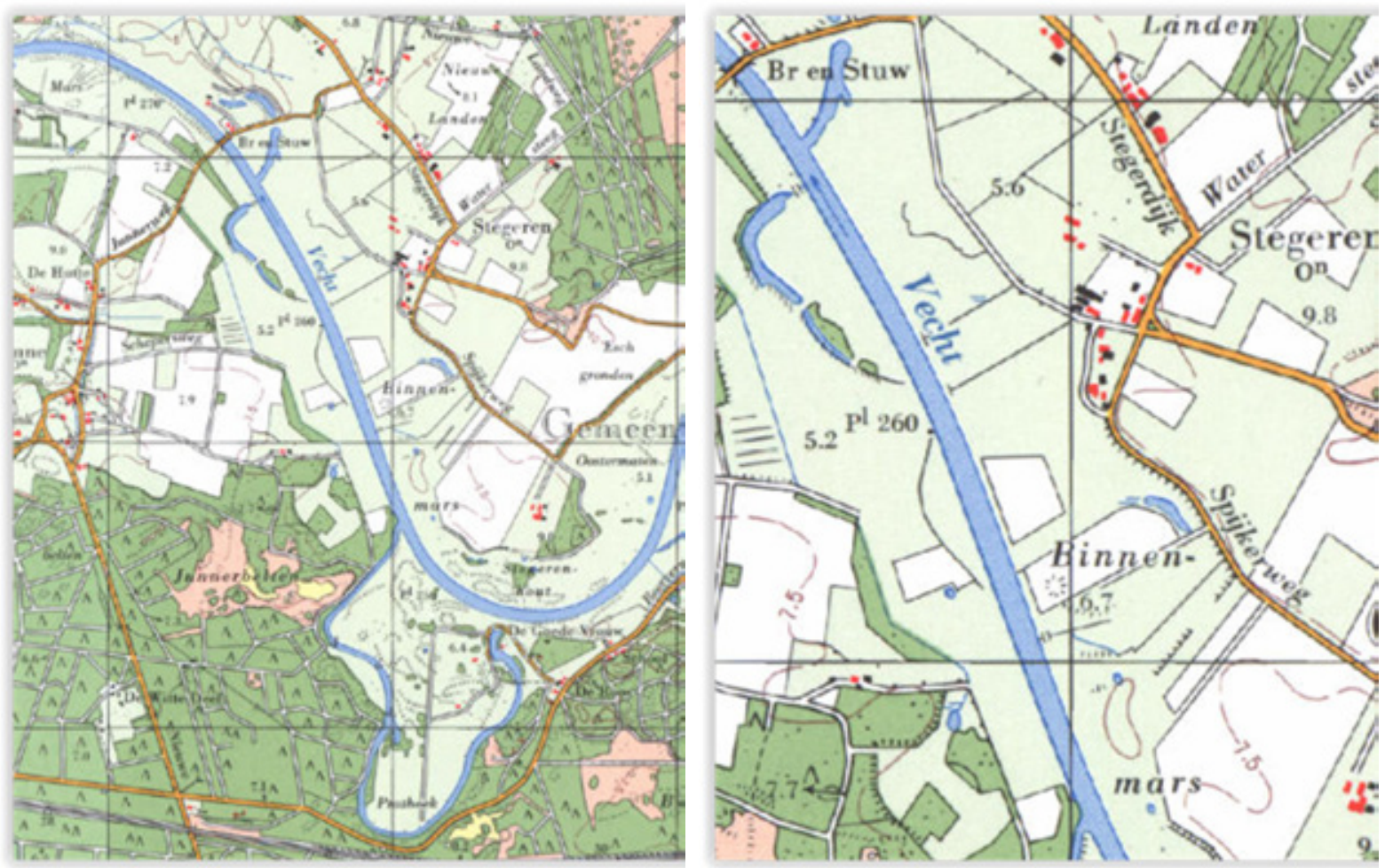

Figuur B1.11 1975 Nieuwe verkaveling, resten oude patronen grotendeels verdwenen. Spijkerweg verlegd langs rand Vechtdal. 

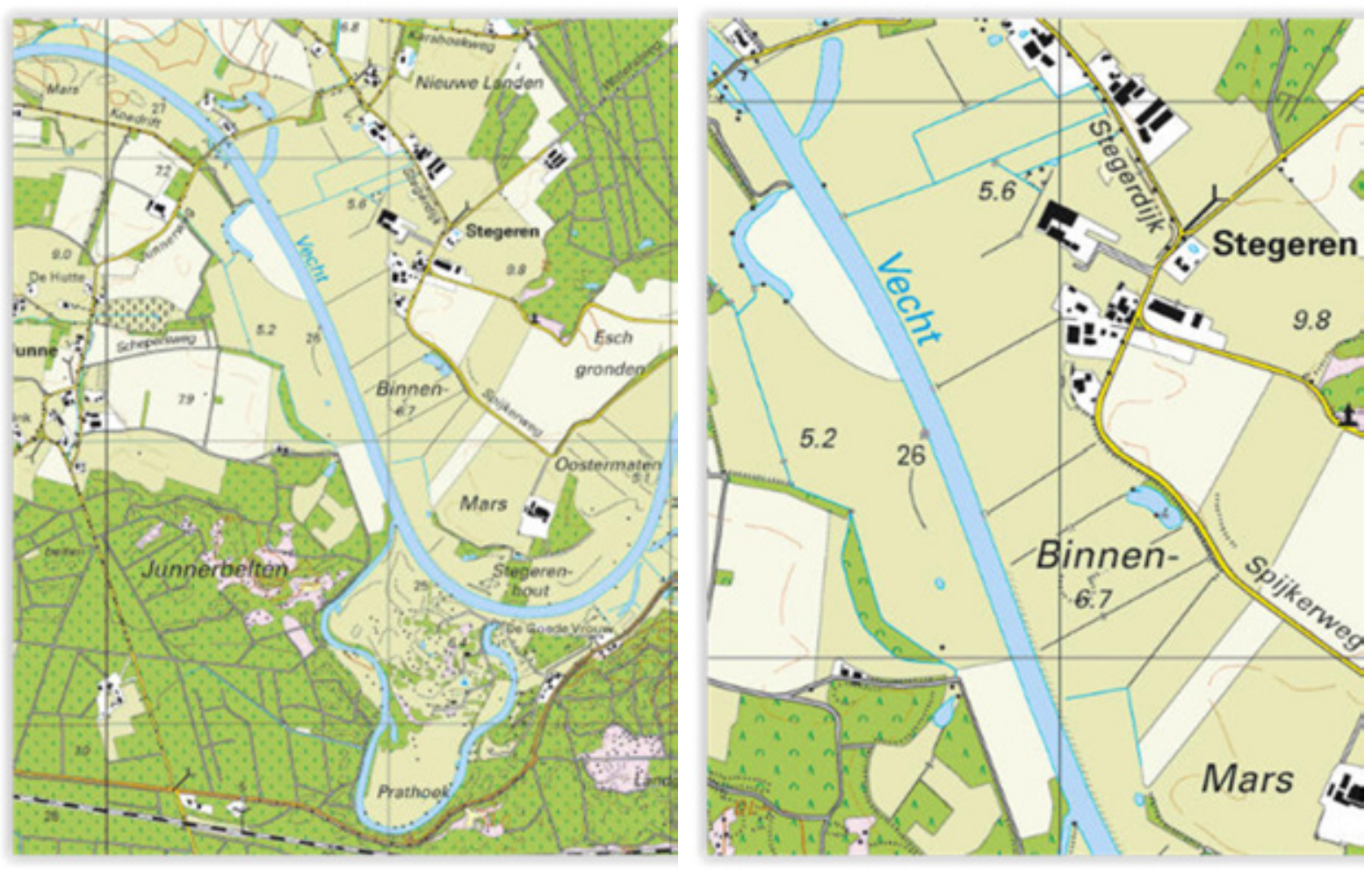

Figuur B1.12 2013 Sporen oude Vechtlopen grotendeels verdwenen.

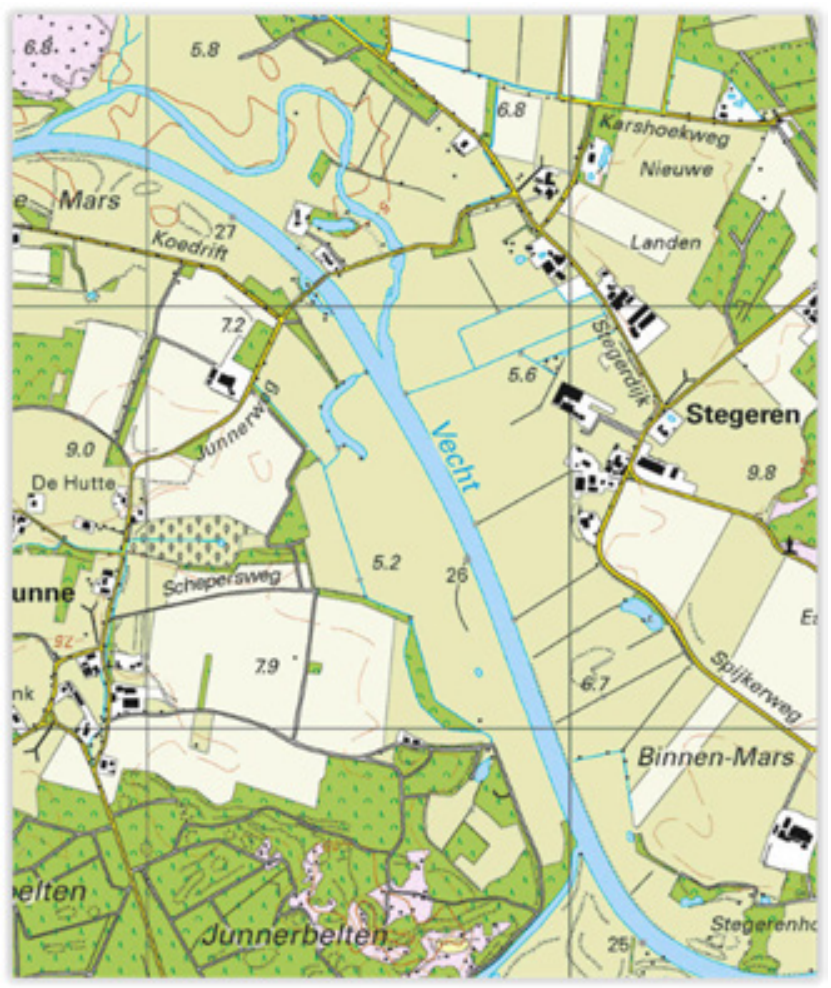

Figuur B1.13 2014 Bypass bij Junne gegraven. 


\section{Bijlage 2 Boorpuntenkaart}

Het bodemkundig veldwerk is eind september, begin oktober 2017 uitgevoerd. Binnen het projectgebied in Figuur 1 zijn 40 boringen verricht tot maximaal 2,5 m-mv. Hierbij zijn de volgende waarnemingen/metingen vastgelegd:

- Beschrijving van het bodemprofiel volgens de WEnR-methode (Ten Cate et al. 1995);

- Schatting van de GHG en GLG in het boorgat;

- Beschrijving van het humusprofiel volgens de Nederlandse humusvorm classificatie (Van Delft et al., 2006);

- Het pH-profiel in 15 boringen door op 4 tot 13 dieptes de bodem-pH te bepalen met indicatorstrookjes (in totaal 131 metingen);

- De actuele grondwaterstand in het boorgat bij 18 boringen;

- Het elektrisch geleidingsvermogen (EGV) van het grondwater in 13 boorgaten en van het oppervlaktewater op 2 plekken (in de Vecht in de oude Vechtarm);

- Bovenstaande gegevens zijn opgenomen in een GIS-systeem in een veldcomputer;

- In het veld is een eerste conceptbodemkaart getekend om de veldkenmerken zo goed mogelijk te kunnen benutten;

- Van een groot deel van de boringen zijn foto's gemaakt van landschap en bodemprofiel.

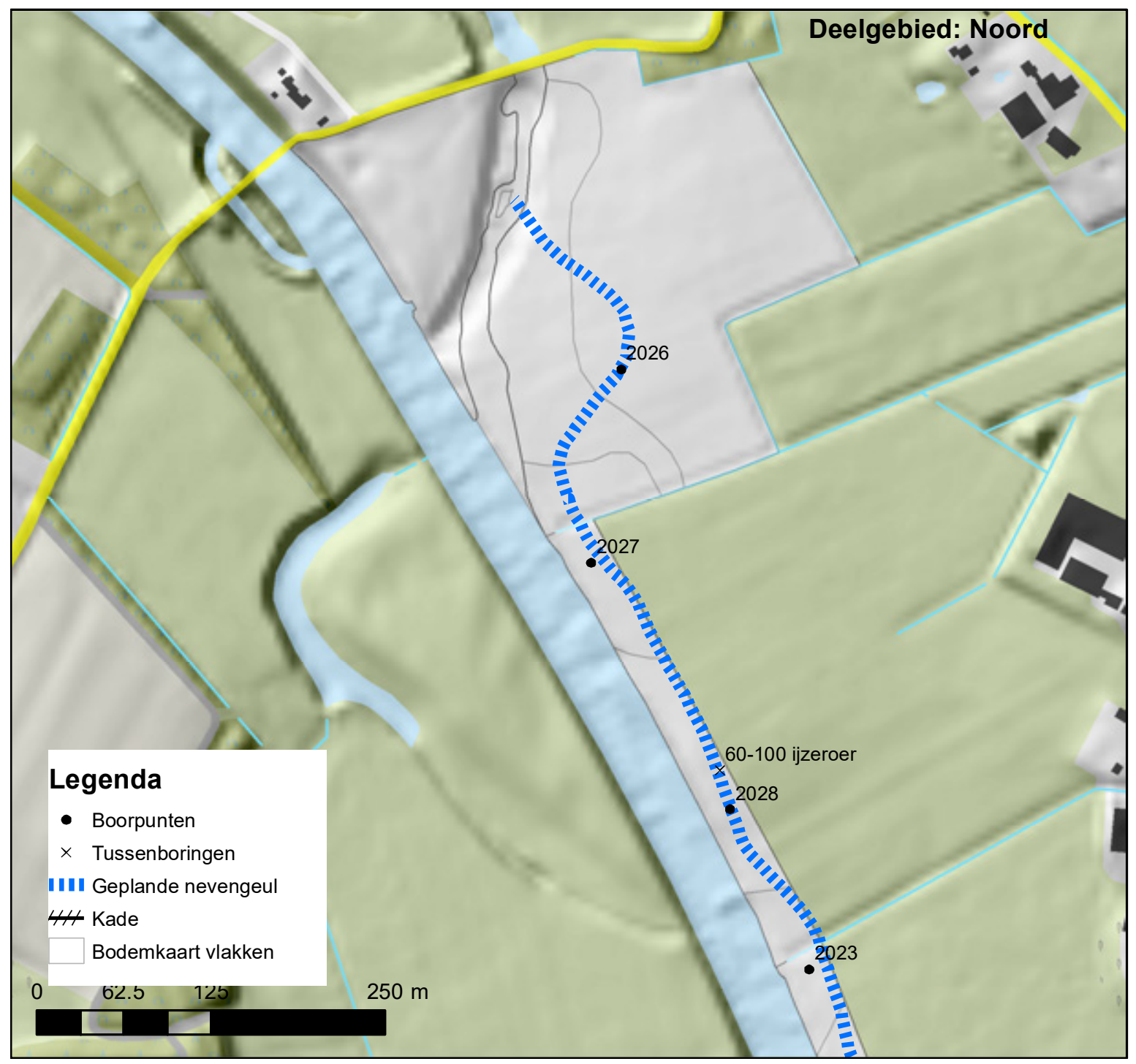




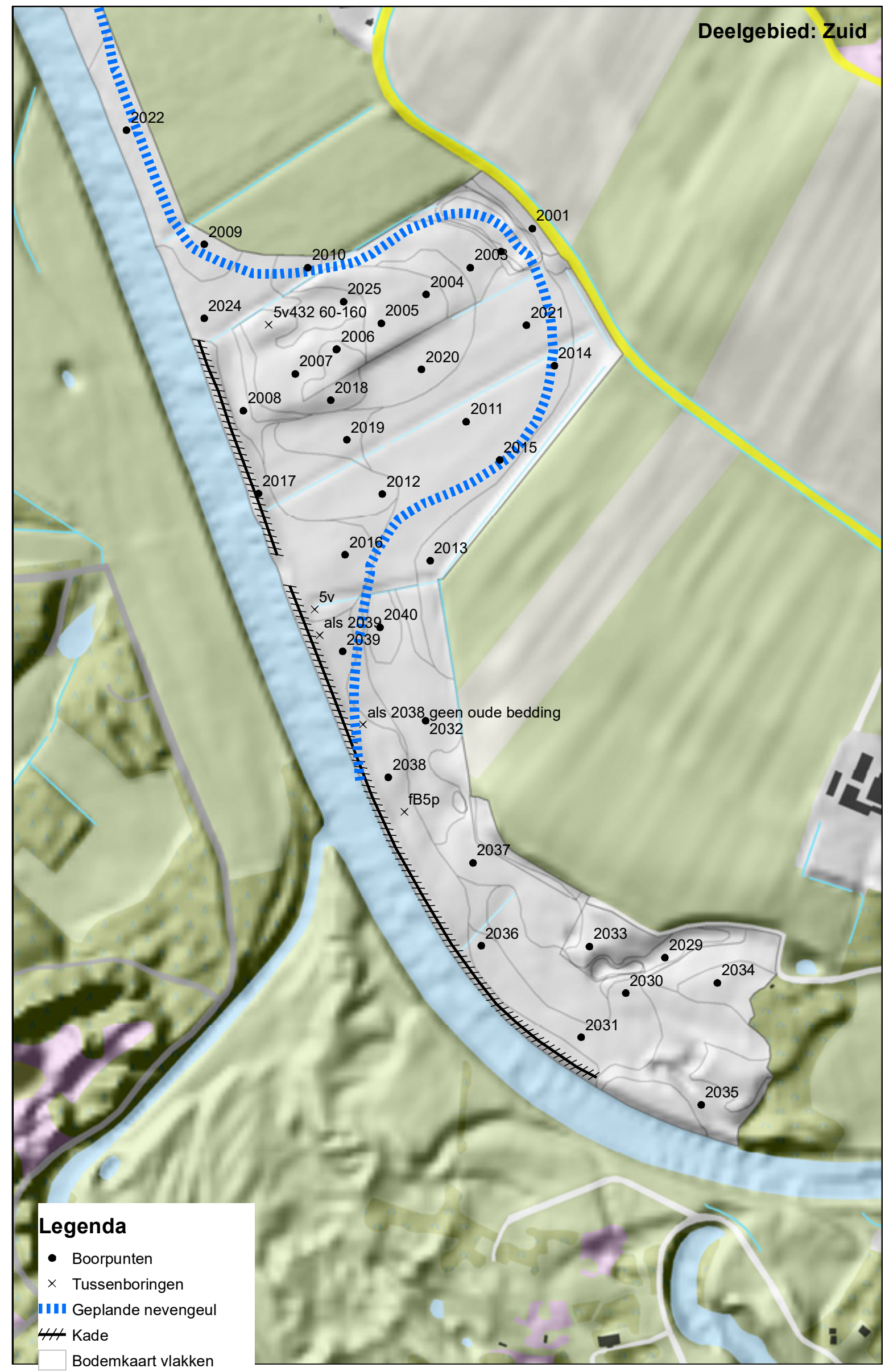




\section{Bijlage 3 Potentiële vegetaties}

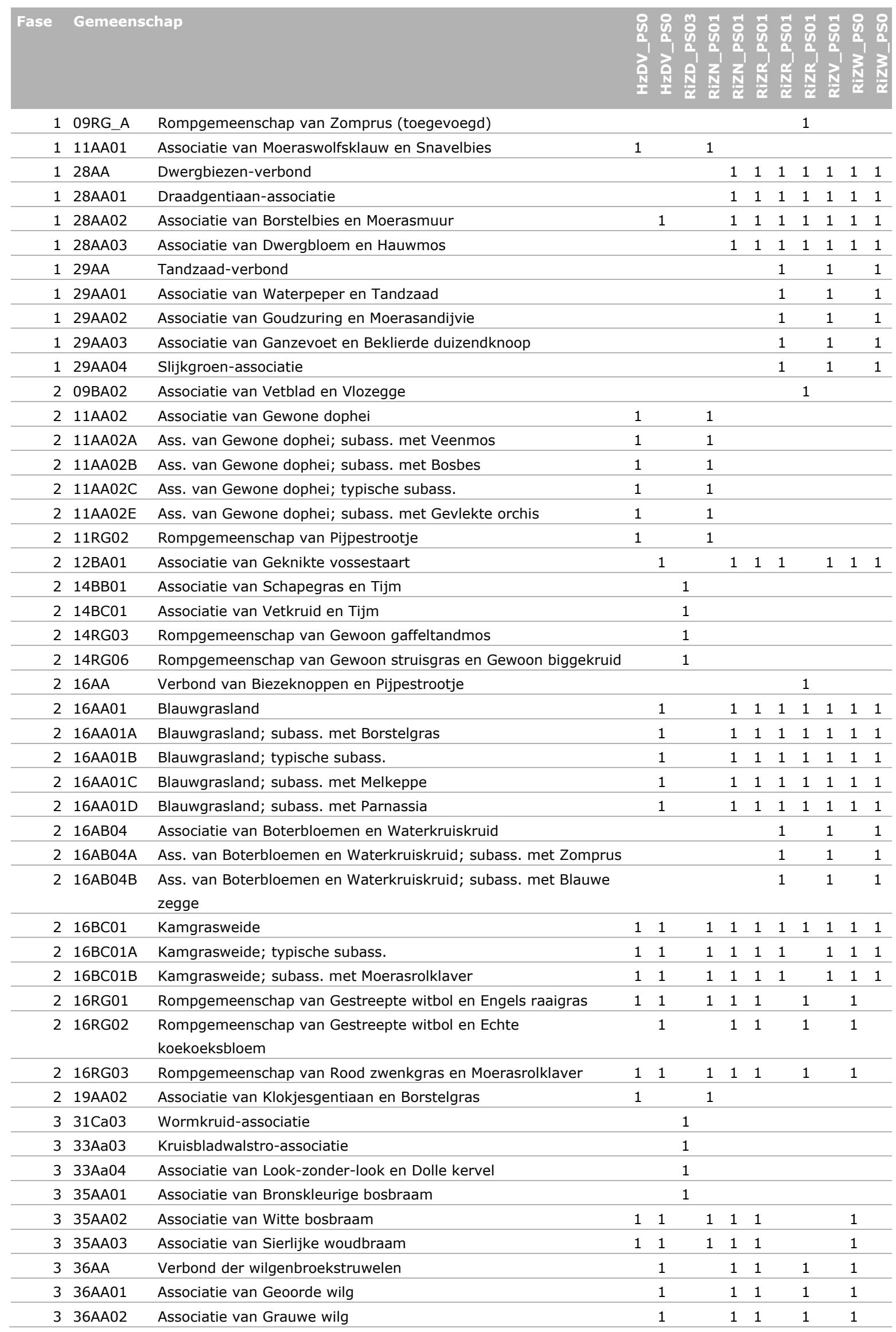




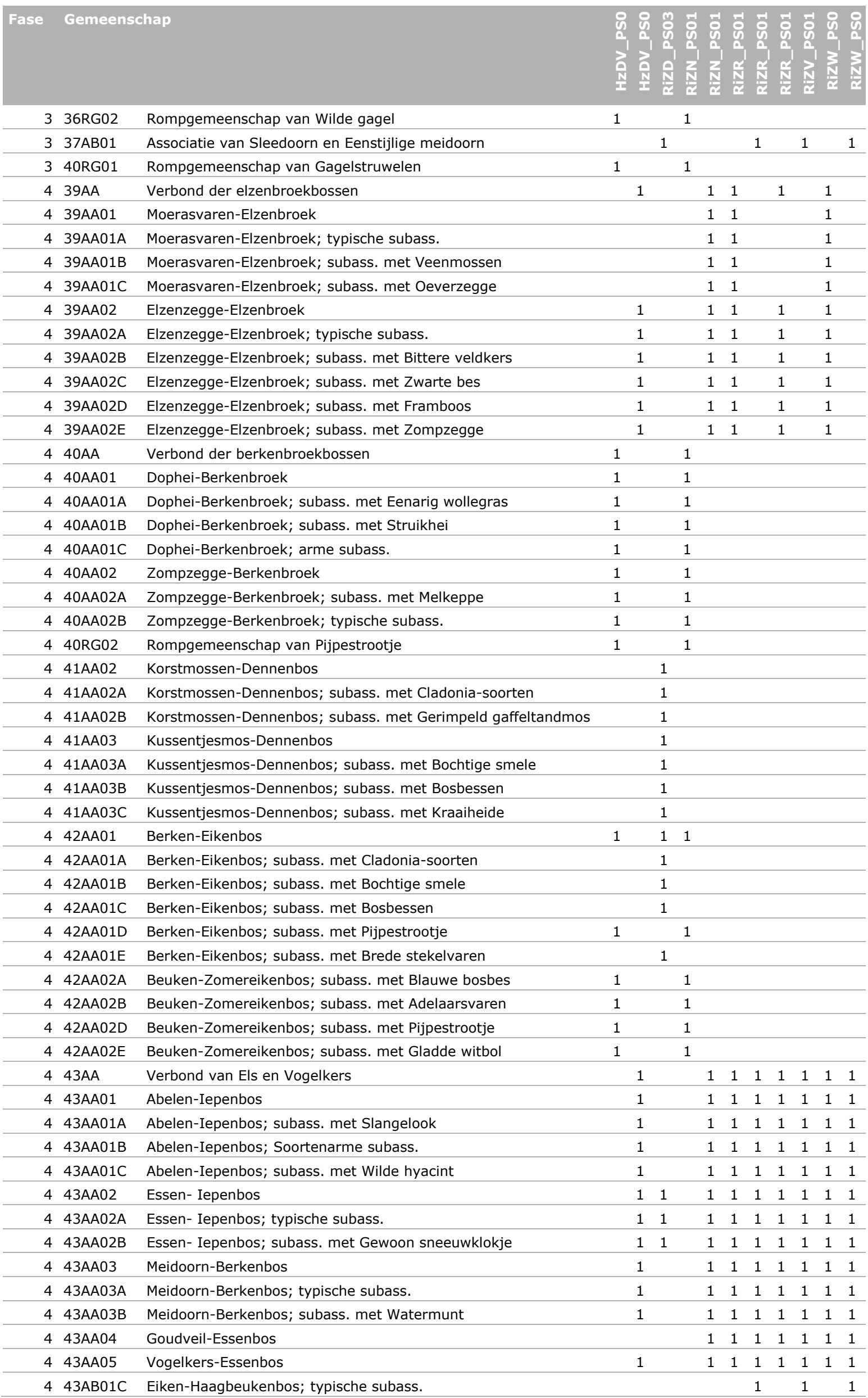




\section{Bijlage 4 Kenmerkende planten- gemeenschappen habitattypen}

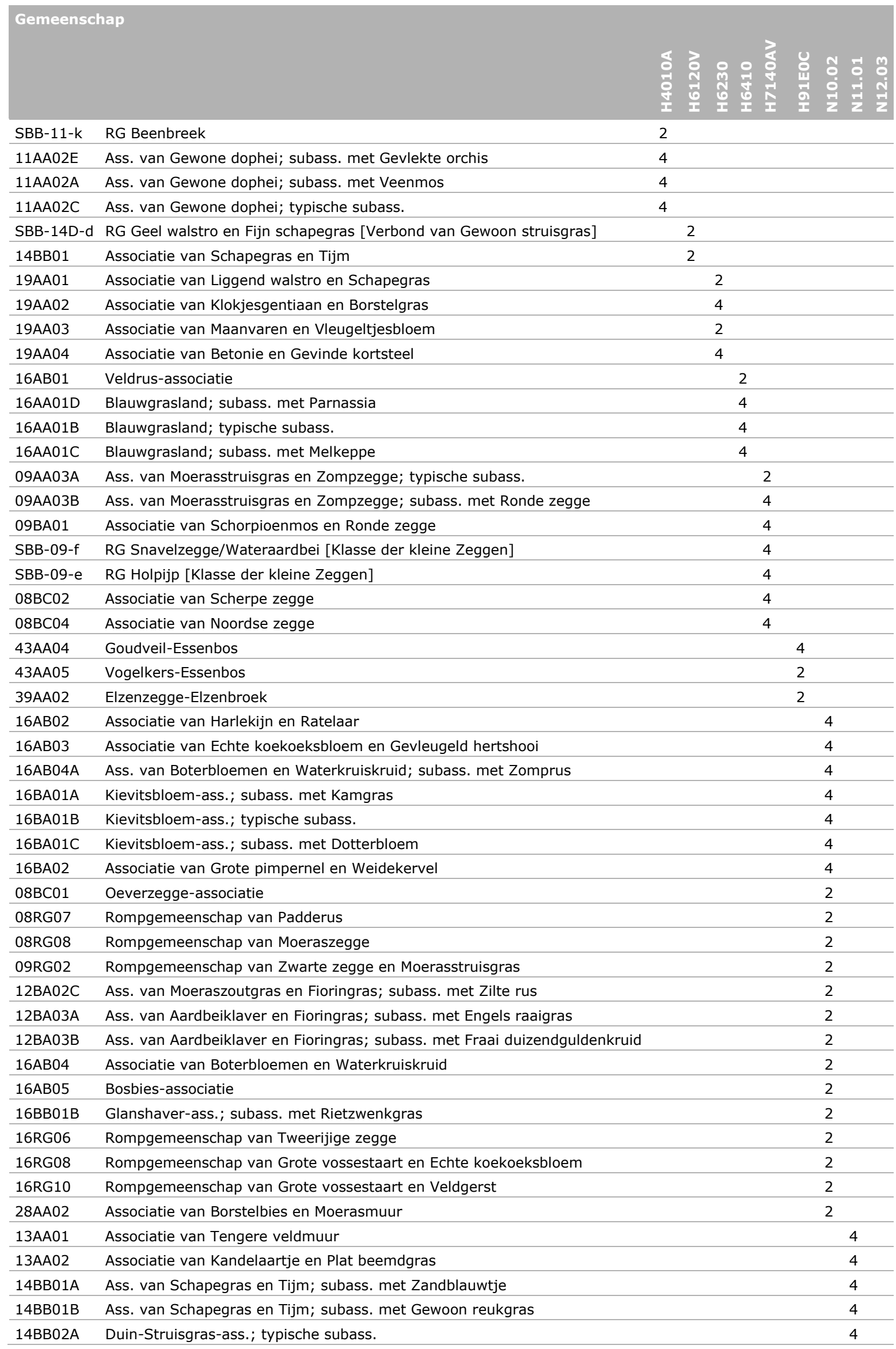


14BB02B Duin-Struisgras-ass.; subass. met Klavertjes

14BC01A Ass. van Vetkruid en Tijm; subass. met Klein vogelpootje

14BC01B Ass. van Vetkruid en Tijm; subass. met Sikkelklaver 4

14BC02A Ass. van Sikkelklaver en Zachte haver; subass. met Gewone veldbies 4

14BC02B Ass. van Sikkelklaver en Zachte haver; subass. met Glanshaver 4

14CB02A Ass. van Wondklaver en Nachtsilene; subass. met Muurpeper 4

14CB02B Ass. van Wondklaver en Nachtsilene; subass. met Pluimstaartmos 4

14RG04 Rompgemeenschap van Cipreswolfsmelk 4

14RG05 Rompgemeenschap van Heelbeen 4

15AA01 Kalkgrasland 4

14BA01 Vogelpootjes-associatie 2

14BB01C Ass. van Schapegras en Tijm; subass. met Zinkviooltje 2

14CB01A Duin-Paardebloem-ass.; subass. met kortsmossen 2

14CB01B Duin-Paardebloem-ass.; typische subass. 2

14CB01C Duin-Paardebloem-ass.; subass. met Bosaardbei 2

14CB01D Duin-Paardebloem-ass.; subass. met Smalle weegbree 2

14RG01 Rompgemeenschap van Zandzegge 2

14RG02 Rompgemeenschap van Vroege haver 2

14RG03 Rompgemeenschap van Gewoon gaffeltandmos 2

14RG06 Rompgemeenschap van Gewoon struisgras en Gewoon biggekruid 2

14RG07 Rompgemeenschap van Hard zwenkgras 2

16BB01D Glanshaver-ass.; subass. met Sikkelklaver 2

16BC01A Kamgrasweide; typische subass. 2

16BC01D Kamgrasweide; subass. met Ruige weegbree 2

$16 \mathrm{BC} 02$ Associatie van Ruige weegbree en Aarddistel 2

16RG12 Rompgemeenschap van Spits havikskruid 2

31AB03 Associatie van Ballote en andere Netels 2

31CA02 Kweekdravik-associatie 2

37AC04 Associatie van rozen en Liguster 2 


\section{Bijlage 5 Methoden voor het bepalen van de realisatiekansen}

\section{Beoordeling affiniteit habitattypen}

Voor het bepalen van de natuurpotenties is in deze kartering allereerst een vergelijking gemaakt van de potentiële vegetaties, horend bij de Fysisch-Geografische eenheden (zie Bijlage 3) met de kenmerkende plantengemeenschappen die horen bij de habitattypen die voor de onderzochte percelen getoetst zijn ( $\S 1.2$ ), om te beoordelen hoe goed het habitattype past bij de bodem. Daarvoor is recentelijk de term 'affiniteit' van het doeltype (beheertype of habitattype) met de FysischGeografische eenheid geïntroduceerd (Van Delft et al., 2017). Per habitattype is volgens onderstaande formule een affiniteitsindex bepaald, die aangeeft welk deel van de potentiële

plantengemeenschappen (volgens de Landschapsleutel) overeenkomt met de plantengemeenschappen voor dat habitattype (zie Bijlage 4).

$$
A f=\left(\frac{N O G}{N P O T}+\frac{N O G}{N K B T}\right) / 2
$$

Waarin: Af = Affiniteit habitattype met FG-eenheid; NOG = Aantal overeenkomstige gemeenschappen; NPOT = Aantal potentiële gemeenschappen in FG_ eenheid; NKBT = Aantal kenmerkende gemeenschappen in habitattype.

In deze formule wordt dus het aandeel overeenkomstige plantengemeenschappen beoordeeld ten opzichte van het aantal potentiële gemeenschappen in de Fysisch-Geografische eenheid én ten opzichte van het aantal kenmerkende gemeenschappen binnen het habitattype.

De maximale waarde van deze affiniteitsindex (theoretisch tussen 0 en 1 , hier niet hoger dan 0,69 ) kan tussen habitattypen sterk verschillen. In een aantal gevallen klopt dat ook, voor een deel komt het ook door onevenwichtigheid in het aantal potentiële plantengemeenschappen per FG-eenheid en het aantal kenmerkende plantengemeenschappen per habitattype. Zo worden in de Landschapsleutel bij sommige fysisch-geografische eenheden veel subassociaties genoemd en wordt bij sommige habitattypen een groot aantal kenmerkende plantengemeenschappen genoemd waarvan er in de FGeenheid slechts een klein deel voorkomt als potentiële vegetatie. Dit levert een relatief geringe overlap en daarmee lagere index op, terwijl de affiniteit van het habitattype met de FG-eenheid niet per se geringer is. De index moet daarom vooral indicatief geïnterpreteerd worden om de verschillende affiniteiten van een habitattype met meerdere FG-eenheden te vergelijken.

\footnotetext{
Abiotische randvoorwaarden habitattypen

Om de huidige abiotische condities binnen de fysiotopen te kunnen vergelijken met de abiotische randvoorwaarden voor een habitattype, hebben we vooral gebruikgemaakt van de abiotische randvoorwaarden zoals deze zijn geformuleerd in Waternood (Runhaar \& Hennekens, 2014). Voor elk habitattype is voor een aantal standplaatskenmerken grenswaarden aangegeven waarmee de optimale condities bepaald zijn (de groene lijn in Figuur 1); de grenswaarden worden dan aangeduid met B1 en B2. Daarnaast zijn er ook nog bereiken aangegeven waarbij het type wel kan voorkomen, maar waarbij de condities suboptimaal zijn ( $A 1$ - B1, blauwe lijn; B2 - A2, rode lijn). Buiten dit bereik (A1 A2) zijn de omstandigheden ongunstig en is het voorkomen van een type onwaarschijnlijk. Voor de habitattypen die voor de onderzochte percelen beoordeeld zijn, zijn in Tabel B5.1 de grenswaarden voor de belangrijkste randvoorwaarden opgenomen.
} 


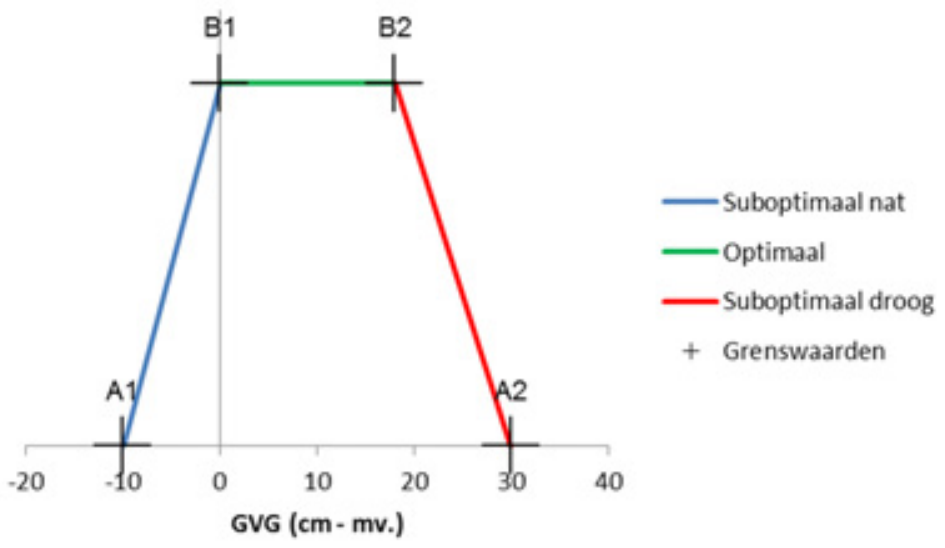

Figuur 1 Schematisch voorbeeld van de realisatiekansen voor een habitattype (H6410) bij de randvoorwaarden voor dat type (GVG).

Tabel B5.1 Abiotische randvoorwaarden voor de Habitattypen volgens Waternood (Runhaar \& Hennekens, 2014). De waarden -999 en 999 betekenen dat er geen ondergrens of bovengrens is voor de betreffende randvoorwaarde. Voor zuurgraad zijn de klassengrenzen gebruikt volgens de ecologische vereisten voor habitattypen (Runhaar et al., 2009).

\begin{tabular}{|c|c|c|c|c|c|c|c|c|c|c|c|}
\hline & & \multicolumn{10}{|c|}{ Grenswaarden } \\
\hline & & A1 & B1 & B2 & A2 & & & A1 & B1 & B2 & A2 \\
\hline \multirow[t]{3}{*}{ GVG cm - mv. } & $\mathrm{H} 4010 \mathrm{~A}$ & -10 & 5 & 29 & 50 & \multirow[t]{3}{*}{ Droogtestress dagen/jaar } & $\mathrm{H} 4010 \mathrm{~A}$ & -999 & -999 & 10 & 20 \\
\hline & $\mathrm{H} 6410$ & -10 & 0 & 18 & 30 & & $\mathrm{H} 6410$ & -999 & -999 & 2 & 12 \\
\hline & H7140AV & -15 & -10 & 5 & 20 & & H7140AV & 0 & 0 & 0 & 0 \\
\hline \multirow[t]{4}{*}{ GLG cm - mv. } & $\mathrm{H} 4010 \mathrm{~A}$ & 0 & 0 & 0 & 0 & \multirow[t]{4}{*}{ Zuurgraad pH-KCl } & $\mathrm{H} 4010 \mathrm{~A}$ & 3.5 & 3.5 & 2.8 & 0 \\
\hline & H6120V & 0 & 0 & 0 & 0 & & H6120V & 6 & 5 & 4.1 & 3.3 \\
\hline & $\mathrm{H} 6410$ & 0 & 0 & 0 & 0 & & $\mathrm{H} 6410$ & 6.8 & 6.1 & 4.1 & 3.5 \\
\hline & H7140AV & -999 & -999 & 26 & 50 & & H7140AV & 7 & 6 & 4.1 & 3.5 \\
\hline
\end{tabular}

Naast de abiotische randvoorwaarden uit Waternood hebben wij gebruikgemaakt van referentiewaarden uit eigen onderzoek (Beets et al., 2000/2005; Van Delft, 2013; Kemmers et al., 2011; De Waal \& Van Delft, 2014).

\section{Realisatiekansen habitattypen}

Voor de vergelijking van de actuele situatie met de gewenste situatie voor de habitattypen hebben wij de abiotische randvoorwaarden overgenomen uit Waternood, versie 3 (Runhaar \& Hennekens 2014). Een voorbeeld is gegeven in Figuur 2, waar het bereik voor de GVG in twee fysiotopen (met een andere codering dan in dit rapport) is uitgezet tegen de abiotische randvoorwaarde voor habitattype H6410 (Blauwgraslanden). Het horizontale deel van de grafiek voor H6410 stelt het optimale bereik voor ('Opt' tussen B1 en B2); in de beide schuine delen wordt het suboptimale bereik aan de natte kant (links: 'Sub-' tussen A1 en B1) en de droge kant (rechts: 'Sub+' tussen B2 en A2) voorgesteld. Bij M2 overlapt het bereik voor de GVG met het suboptimale bereik van H6410 aan de droge kant en een klein stukje met het optimale bereik, het grootste deel van het bereik van M2 is te droog (IndexGVG = 0.79). Daardoor wordt de GVG in deze fysiotoop als minder geschikt beoordeeld voor dit habitattype. Fysiotoop L2 blijkt qua GVG beter geschikt te zijn. Het grootste deel van het bereik voor GVG valt samen met het optimaal bereik voor het habitattype, de rest valt binnen het suboptimale deel aan de natte kant (IndexGVG $=-0.21$ ). 


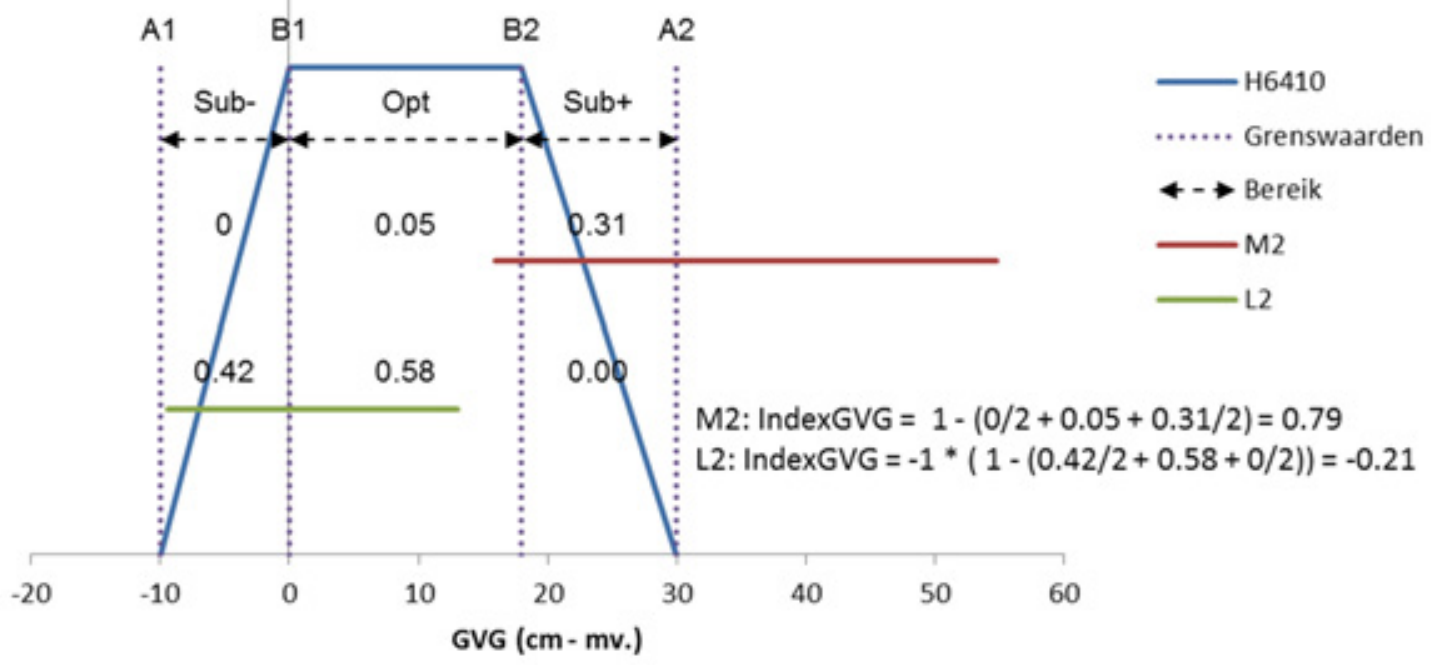

Figuur 2 Schematisch voorbeeld van de vergelijking van het bereik voor de GVG in de fysiotopen M2 en L2 met de abiotische randvoorwaarden van habitattype H6410 (Blauwgraslanden). De fractie van het bereik in een fysiotoop dat samenvalt met elk deelbereik van de randvoorwaarden, is aangegeven boven het bereik voor de fysiotopen (sub- = suboptimaal links, Opt=optimaal en Sub+ = Suboptimaal rechts). De totale overlap is berekend uit de som van deze fracties, waar de waarden in de suboptimale bereiken gehalveerd is. Bij M2 is dat 0 voor Sub-, 0.05 voor Opt en 0.31 voor Sub+. De warden voor Sub+/- worden gehalveerd, dus: de overlap is $0 / 2+0.05+0.31 / 2=0.21$. De index voor GVG is berekend uit 1 - de totale overlap. Bij L2 ligt het zwaartepunt van het bereik links (natter) van het bereik van het habitattype, daarom is de index negatief gemaakt. De index geeft dus de mate van beperking aan die volgt uit het bereik in de fysiotoop: $0=$ geen beperking; $1=$ ongeschikt, te droog; -1 = ongeschikt, te nat; tussenliggende waarden geven een meer of minder grote beperking aan.

Tabel B5.2 Bereik voor de actuele standplaatskenmerken voor grondwaterstanden (GHG, GVG, GLG in $\mathrm{cm}-m v .$, droogtestress (aantal dagen met vochttekort) en zuurgraad ( $\mathrm{pH}-\mathrm{KCl}$ ) binnen de fysiotopen.

\begin{tabular}{|c|c|c|c|c|c|c|c|c|c|c|c|}
\hline \multirow[b]{2}{*}{ Fysiotoop } & \multirow[b]{2}{*}{ Gt } & \multicolumn{2}{|c|}{$\begin{array}{l}\text { GVG } \\
\mathrm{cm}-\mathrm{mv} \text {. }\end{array}$} & \multicolumn{2}{|c|}{$\begin{array}{l}\text { GHG } \\
\mathrm{cm}-\mathrm{mv} .\end{array}$} & \multicolumn{2}{|l|}{$\begin{array}{l}\text { GLG } \\
\mathrm{cm}-\mathrm{mv} .\end{array}$} & \multicolumn{2}{|l|}{$\begin{array}{l}\text { Droogtestress } \\
\text { Dagen/jaar }\end{array}$} & \multicolumn{2}{|l|}{$\begin{array}{l}\text { Zuurgraad } \\
\mathrm{pH}-\mathrm{KCl}\end{array}$} \\
\hline & & Min & Max & Min & Max & Min & Max & Min & Max & Min & Max \\
\hline HzBD PS012 NA & IIIa & 27.8 & 48.1 & 15 & 30 & 70 & 120 & 0 & 0 & 3.28 & 3.47 \\
\hline HzBD PS013 NA & IIIa & 7.2 & 38.0 & -10 & 15 & 65 & 130 & 0 & 0 & 3.37 & 5.95 \\
\hline HzBD PS013 ZN & IIa & -3.3 & 28.1 & -20 & 10 & 50 & 95 & 0 & 0 & 5.76 & 6.23 \\
\hline HzDV_PS012 VN & $\mathrm{Va}$ & 32.3 & 51.5 & 10 & 30 & 120 & 140 & 0 & 4 & 3.85 & 4.14 \\
\hline HzDV_PS012 VO & IIIb-Vb & 42.5 & 69.6 & 25 & 40 & 110 & 200 & 0 & 35 & 3.18 & 3.37 \\
\hline RiZD_PS031C DR & VI-VIII & 69.6 & 109.1 & 55 & 90 & 130 & 200 & 2 & 35 & 4.23 & 4.42 \\
\hline RiZD_PS031C VO & IIIb-Vb & 35.1 & 65.9 & 20 & 45 & 90 & 155 & 0 & 17 & 4.23 & 4.42 \\
\hline RiZN_PS012 DR & VI-VIII & 56.0 & 97.8 & 40 & 80 & 120 & 180 & 0 & 26 & 3.37 & 3.85 \\
\hline RiZN_PS013 NA & IIIa & 17.6 & 41.9 & 0 & 20 & 80 & 130 & 0 & 2 & 4.14 & 4.33 \\
\hline RiZN_PS013 VO & IIIb-Vb & 33.4 & 56.0 & 20 & 40 & 80 & 120 & 0 & 0 & 4.23 & 4.42 \\
\hline RiZN_PS013 ZN & wIa-IIa & 8.6 & 27.8 & -5 & 15 & 50 & 70 & 0 & 0 & 4.23 & 4.42 \\
\hline RiZR_PS013 NA & IIIa & 17.6 & 38.5 & 0 & 20 & 80 & 110 & 0 & 0 & 4.14 & 4.33 \\
\hline RiZR_PS014 NA & IIIa & 31.2 & 42.5 & 15 & 25 & 90 & 110 & 0 & 0 & 4.14 & 4.33 \\
\hline RiZR_PS014 ZN & wIa-IIa & 8.6 & 24.7 & -5 & 10 & 50 & 75 & 0 & 0 & 3.47 & 4.42 \\
\hline RiZR_PS016 ZN & wIa-IIa & -18.0 & 2.9 & -30 & -10 & 10 & 40 & 0 & 0 & 5.76 & 6.71 \\
\hline RiZV_PS014 NA & IIIa & 17.6 & 48.1 & 0 & 30 & 80 & 120 & 0 & 0 & 4.14 & 4.71 \\
\hline RiZV_PS014 VO & IIIb-Vb & 31.7 & 65.1 & 20 & 45 & 70 & 150 & 0 & 9 & 4.14 & 4.52 \\
\hline RiZV_PS014 ZN & wIa-IIa & 8.6 & 33.4 & -5 & 20 & 50 & 80 & 0 & 0 & 4.33 & 4.80 \\
\hline RiZW_PS013 VO & IIIb-Vb & 36.8 & 58.9 & 20 & 35 & 100 & 160 & 0 & 14 & 4.23 & 4.42 \\
\hline RiZW_PS014 VO & IIIb-Vb & 36.8 & 58.9 & 20 & 35 & 100 & 160 & 0 & 14 & 4.23 & 4.42 \\
\hline
\end{tabular}


Volgens dit principe hebben we in Bijlage 6 alle combinaties voor fysiotoop en habitattype beoordeeld voor GVG, GLG óf droogtestress en zuurgraad. Hierbij zijn de waarden van de standplaatsfactoren per fysiotoop in Tabel B5.2 vergeleken met de abiotische randvoorwaarden van de habitattypen volgens Tabel 5.1. Voor elke standplaatsfactor is de mate van beperking bepaald door de fracties overlap in het optimale bereik en de beide suboptimale bereiken samen te nemen, waarbij het optimale bereik een zwaarder gewicht heeft gekregen (Figuur 2 ). De fractie overlap ( $0=$ geen, $1=$ volledig) is omgerekend naar een index voor de mate van beperking: index = 1 - overlap (overlap $1=$ index 0 ; overlap $0=$ index 1 ). Bij overlap $<1$ (index voor beperking $>0$ ) is aangegeven in welke richting de beperking werkt: een positieve index wil zeggen 'te droog' of 'te basisch', een negatieve index betekent 'te nat' of 'te zuur'.

Tabel 5.3 Realisatiekans (Real. 1 en Real. 2) per fysiotoop voor de meest waarschijnlijke habitattypen (Doelt. 1 en Doelt. 2). Deze habitattypen volgen uit de beoordeling van de affiniteit van de habitattypen met de Fysisch-Geografische eenheden ( $\$ 4.2$ en Figuur 4.2). Door voor deze habitattypen de overeenkomst van de standplaatsfactoren binnen het fysiotoop met de abiotische randvoorwaarden van de habitattypen te vergelijken, is de realisatiekans berekend.

\begin{tabular}{|c|c|c|c|c|c|c|c|c|c|}
\hline \multirow[b]{2}{*}{ Fysiotoop } & \multirow[b]{2}{*}{ Opp } & \multicolumn{4}{|c|}{ Korte vegetaties } & \multicolumn{4}{|l|}{ Bos } \\
\hline & & Doelt. 1 & Real. 1 & Doelt. 2 & Real. 2 & Doelt. 1 & Real. 1 & Doelt. 2 & Real. 2 \\
\hline HzDV_PS012 VN & 1.01 & $\mathrm{H} 4010 \mathrm{~A}$ & 0 & H7140AV & 0 & geen & 0 & geen & 0 \\
\hline RiZD_PS031C DR & 1.64 & H6120V & 0.78 & N11.01 & 0 & geen & 0 & geen & 0 \\
\hline RiZD_PS031C VO & 1.62 & H6120V & 0.1 & N11.01 & 0 & geen & 0 & geen & 0 \\
\hline RiZN_PS013 NA & 5.27 & $\mathrm{H} 6410$ & 0.26 & N10.02 & 0 & H91E0C & 0 & geen & 0 \\
\hline RiZN_PS013 VO & 0.55 & $\mathrm{H} 6410$ & 0 & N10.02 & 0 & H91E0C & 0 & geen & 0 \\
\hline RiZN_PS013 ZN & 1.12 & $\mathrm{H} 6410$ & 0.75 & N10.02 & 0 & H91E0C & 0.245 & geen & 0 \\
\hline RiZR_PS013 NA & 0.98 & $\mathrm{H} 6410$ & 0.31 & N10.02 & 0 & H91E0C & 0 & geen & 0 \\
\hline RiZV_PS014 NA & 1.31 & $\mathrm{H} 6410$ & 0.21 & N10.02 & 0 & H91E0C & 0 & geen & 0 \\
\hline RiZV_PS014 VO & 0.87 & H6410 & 0 & N10.02 & 0 & H91E0C & 0 & geen & 0 \\
\hline RiZV_PS014 ZN & 1.16 & $\mathrm{H} 6410$ & 0.62 & N10.02 & 0 & H91E0C & 0.146 & geen & 0 \\
\hline RiZW_PS013 VO & 5.44 & $\mathrm{H} 6410$ & 0 & N10.02 & 0 & H91E0C & 0 & geen & 0 \\
\hline RiZW_PS014 VO & 1.84 & H6410 & 0 & N10.02 & 0 & H91E0C & 0 & geen & 0 \\
\hline
\end{tabular}

Per fysiotoop zijn de realisatiekansen voor de meest waarschijnlijke habitattypen in korte vegetaties en bos berekend (Tabel 5.3). In een aantal gevallen blijkt de groeiplaats niet geschikt te zijn voor de habitattypen die er het beste bij passen op grond van de landschapsecologisch positie. In de onderzochte percelen is bijvoorbeeld voor de realisatiekans voor H4010A 'Vochtige heiden (hogere zandgronden)' 0 in fysiotopen waar dit habitattype wel goed bij zou passen. In Bijlage 6 zijn de knelpunten per standplaatsfactor opgenomen. Hieruit blijkt dat de $\mathrm{pH}$ in deze percelen vaak te hoog is voor heide. Dat komt door de inspoeling van calciumionen uit het kalkrijke, opgebrachte materiaal, waardoor de zuurgraad niet past bij de Fysisch-Geografische eenheid. Waarschijnlijk is dat een tijdelijke beperking, omdat het in principe infiltratieprofielen zijn die op termijn zullen verzuren (Bijlage 6). In andere situaties is de groeiplaats te droog (bijvoorbeeld voor H6410 'Blauwgraslanden') of te nat (bijvoorbeeld voor H9120 'Beukenbossen met hulst'). Op basis van de hoogste realisatiekans binnen een fysiotoop is voor korte vegetaties en bos in Figuur 4.2 en Figuur 4.3 aangegeven wat de meest waarschijnlijke habitattypen zijn. 


\section{Bijlage 6 Realisatiekansen habitattypen}

In onderstaande tabel zijn per fysiotoop de indexen berekend die aangeven of de actuele grondwaterstanden en zuurgraad voldoen aan de abiotische randvoorwaarden van de habitattypen. De index geeft aan in hoeverre de waarden afwijken van de randvoorwaarden: $0=$ voldoet geheel, $1=$ voldoet niet, te droog/te basisch, -1 voldoet niet, te nat/te zuur. Waarden ongelijk aan 0 en tussen -1 en 1 geven een gedeeltelijke beperking aan. $9=$ er is geen randvoorwaarde geformuleerd. In de kolom 'Real.' is de realisatiekans berekend (tussen 0 en 1 ) op basis van de indexen. Onder aan de tabel is per fysiotoop aangegeven wat het meest waarschijnlijke habitattype (Doelt. 1) is (met de hoogste realisatiekans) en wat een ander mogelijk habitattype is (met de op één na hoogste realisatiekans). Dit is apart aangegeven voor korte vegetaties en bos. Dat is afhankelijk van het beheer. De methode is beschreven in Bijlage 5.

\begin{tabular}{|c|c|c|c|c|c|c|c|c|c|c|c|}
\hline \multirow[b]{2}{*}{ Fysiotoop } & \multirow[b]{2}{*}{ Opp } & \multicolumn{4}{|c|}{ Indexen H4010A } & \multirow[t]{2}{*}{ Real. } & \multicolumn{4}{|c|}{ Indexen H6120V } & \multirow[t]{2}{*}{ Real. } \\
\hline & & GVG & GLG & DS & ZG & & GVG & GLG & DS & ZG & \\
\hline HzDV_PS012 VN & 1.01 & 0.54 & 9 & 0 & 1 & 0 & -1 & 9 & 0 & -0.44 & 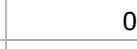 \\
\hline HzDV_PS012 VO & 0.58 & 0.86 & 9 & 0.57 & 0 & 0.06 & -0.82 & 9 & 0 & -0.81 & 0.03 \\
\hline RiZD_PS031C DR & 1.64 & 1 & 9 & 0.61 & 1 & 0 & -0.22 & 9 & 0 & 0 & 0.78 \\
\hline RiZD_PS031C Vo & 1.62 & 0.76 & 9 & 0.21 & 1 & 0 & -0.9 & 9 & 0 & 0 & 0.1 \\
\hline RiZN_PS012 DR & 1.66 & 1 & 9 & 0.42 & 0.74 & 0 & -0.42 & 9 & 0 & -0.5 & 0.29 \\
\hline RiZN_PS013 NA & 5.27 & 0.26 & 9 & 0 & 1 & 0 & -1 & 9 & 0 & 0 & 0 \\
\hline RiZN_PS013 VO & 0.55 & 0.63 & 9 & 0 & 1 & 0 & -1 & 9 & 0 & 0 & 0 \\
\hline RiZN_PS013 ZN & 1.12 & 0 & 9 & 0 & 1 & 0 & -1 & 9 & 0 & 0 & 0 \\
\hline RiZR_PS013 NA & 0.98 & 0.23 & 9 & 0 & 1 & 0 & -1 & 9 & 0 & 0 & 0 \\
\hline RiZR_PS014 NA & 0.53 & 0.5 & 9 & 0 & 1 & 0 & -1 & 9 & 0 & 0 & 0 \\
\hline RiZR_PS014 ZN & 1.56 & 0 & 9 & 0 & 0.97 & 0.03 & -1 & 9 & 0 & -0.33 & 0 \\
\hline RiZR_PS016 ZN & 0.19 & -0.69 & 9 & 0 & 1 & 0 & -1 & 9 & 0 & 0.87 & 0 \\
\hline RiZV_PS014 NA & 1.31 & 0.31 & 9 & 0 & 1 & 0 & -1 & 9 & 0 & 0 & 0 \\
\hline RiZV_PS014 VO & 0.87 & 0.73 & 9 & 0 & 1 & 0 & -0.92 & 9 & 0 & 0 & 0.08 \\
\hline RiZV_PS014 ZN & 1.16 & 0.09 & 9 & 0 & 1 & 0 & -1 & 9 & 0 & 0 & 0 \\
\hline RiZW_PS013 VO & 5.44 & 0.7 & 9 & 0.14 & 1 & 0 & -1 & 9 & 0 & 0 & 0 \\
\hline RiZW_PS014 VO & 1.84 & 0.7 & 9 & 0.14 & 1 & 0 & -1 & 9 & 0 & 0 & 0 \\
\hline
\end{tabular}

\begin{tabular}{|c|c|c|c|c|c|c|c|c|c|c|c|}
\hline \multirow[b]{2}{*}{ Fysiotoop } & \multirow[b]{2}{*}{ Opp } & \multicolumn{4}{|c|}{ Indexen H6230 } & \multirow[t]{2}{*}{ Real. } & \multicolumn{4}{|c|}{ Indexen H6410 } & \multirow[t]{2}{*}{ Real. } \\
\hline & & GVG & GLG & DS & ZG & & GVG & GLG & DS & ZG & \\
\hline HzDV_PS012 VN & 1.01 & -0.41 & 9 & 0 & 0 & 0.59 & 1 & 9 & 0.25 & -0.44 & 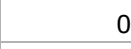 \\
\hline HzDV_PS012 VO & 0.58 & -0.1 & 9 & 0.1 & -0.5 & 0.4 & 1 & 9 & 0.8 & -1 & 0 \\
\hline RiZD_PS031C DR & 1.64 & 0 & 9 & 0.11 & 0 & 0.89 & 1 & 9 & 0.85 & 0 & 4 \\
\hline RiZD_PS031C VO & 1.62 & -0.21 & 9 & 0 & 0 & 0.79 & 1 & 9 & 0.59 & 0 & 0 \\
\hline RiZN_PS012 DR & 1.66 & 0 & 9 & 0 & -0.13 & 0.87 & 1 & 9 & 0.73 & -0.63 & 0 \\
\hline RiZN_PS013 NA & 5.27 & -0.5 & 9 & 0 & 0 & 0.5 & 0.74 & 9 & 0 & 0 & 0.26 \\
\hline RiZN_PS013 VO & 0.55 & -0.32 & 9 & 0 & 0 & 0.68 & 1 & 9 & 0 & 0 & 0 \\
\hline RiZN_PS013 ZN & 1.12 & -0.5 & 9 & 0 & 0 & 0.5 & 0.25 & 9 & 0 & 0 & 0.75 \\
\hline RiZR_PS013 NA & 0.98 & -0.5 & 9 & 0 & 0 & 0.5 & 0.69 & 9 & 0 & 0 & 0.31 \\
\hline RiZR_PS014 NA & 0.53 & -0.5 & 9 & 0 & 0 & 0.5 & 1 & 9 & 0 & 0 & 0 \\
\hline RiZR_PS014 ZN & 1.56 & -0.5 & 9 & 0 & -0.02 & 0.49 & 0.21 & 9 & 0 & -0.35 & 0.52 \\
\hline RiZR_PS016 ZN & 0.19 & -1 & 9 & 0 & 0.82 & 0 & -0.62 & 9 & 0 & 0.32 & 0.26 \\
\hline RiZV_PS014 NA & 1.31 & -0.5 & 9 & 0 & 0 & 0.5 & 0.79 & 9 & 0 & 0 & 0.21 \\
\hline RiZV_PS014 VO & 0.87 & -0.24 & 9 & 0 & 0 & 0.76 & 1 & 9 & 0.39 & 0 & 0 \\
\hline RiZV_PS014 ZN & 1.16 & -0.5 & 9 & 0 & 0 & 0.5 & 0.38 & 9 & 0 & 0 & 0.62 \\
\hline RiZW_PS013 VO & 5.44 & -0.25 & 9 & 0 & 0 & 0.75 & 1 & 9 & 0.5 & 0 & 0 \\
\hline RiZW_PS014 VO & 1.84 & -0.25 & 9 & 0 & 0 & 0.75 & 1 & 9 & 0.5 & 0 & 0 \\
\hline
\end{tabular}




\begin{tabular}{|c|c|c|c|c|c|c|c|c|c|c|c|}
\hline \multirow[b]{2}{*}{ Fysiotoop } & \multirow[b]{2}{*}{ Opp } & \multicolumn{4}{|c|}{ Indexen H7140AV } & \multirow[t]{2}{*}{ Real. } & \multicolumn{4}{|c|}{ Indexen H91E0C } & \multirow[t]{2}{*}{ Real. } \\
\hline & & GVG & GLG & DS & ZG & & GVG & GLG & DS & ZG & \\
\hline HzDV_PS012 VN & 1.01 & 1 & 1 & 9 & -0.44 & 0 & 0.5 & 1 & 9 & -0.5 & 0 \\
\hline HzDV_PS012 VO & 0.58 & 1 & 1 & 9 & -1 & 0 & 0.5 & 1 & 9 & -0.5 & 0 \\
\hline RiZD_PS031C DR & 1.64 & 1 & 1 & 9 & 0 & 0 & 0.87 & 1 & 9 & -0.5 & 0 \\
\hline RiZD_PS031C Vo & 1.62 & 1 & 1 & 9 & 0 & 0 & 0.5 & 1 & 9 & -0.5 & 0 \\
\hline RiZN_PS012 DR & 1.66 & 1 & 1 & 9 & -0.63 & 0 & 0.71 & 1 & 9 & -0.5 & 0 \\
\hline RiZN_PS013 NA & 5.27 & 0.95 & 1 & 9 & 0 & 0 & 0.31 & 1 & 9 & -0.5 & 0 \\
\hline RiZN_PS013 VO & 0.55 & 1 & 1 & 9 & 0 & 0 & 0.5 & 1 & 9 & -0.5 & 0 \\
\hline RiZN_PS013 ZN & 1.12 & 0.7 & 1 & 9 & 0 & 0 & 0.02 & 0.5 & 9 & -0.5 & 0.24 \\
\hline RiZR_PS013 NA & 0.98 & 0.94 & 1 & 9 & 0 & 0 & 0.28 & 1 & 9 & -0.5 & 0 \\
\hline RiZR_PS014 NA & 0.53 & 1 & 1 & 9 & 0 & 0 & 0.5 & 1 & 9 & -0.5 & 0 \\
\hline RiZR_PS014 ZN & 1.56 & 0.64 & 1 & 9 & -0.35 & 0 & 0 & 0.6 & 9 & -0.5 & 0.2 \\
\hline RiZR_PS016 ZN & 0.19 & -0.26 & 0.23 & 9 & 0.37 & 0.35 & -0.48 & 0 & 9 & 0 & 0.52 \\
\hline RiZV_PS014 NA & 1.31 & 0.96 & 1 & 9 & 0 & 0 & 0.35 & 1 & 9 & -0.5 & 0 \\
\hline RiZV_PS014 VO & 0.87 & 1 & 1 & 9 & 0 & 0 & 0.5 & 1 & 9 & -0.5 & 0 \\
\hline RiZV_PS014 ZN & 1.16 & 0.77 & 1 & 9 & 0 & 0 & 0.13 & 0.67 & 9 & -0.5 & 0.15 \\
\hline RiZW_PS013 VO & 5.44 & 1 & 1 & 9 & 0 & 0 & 0.5 & 1 & 9 & -0.5 & 0 \\
\hline \multirow[t]{2}{*}{ RiZW_PS014 VO } & 1.84 & 1 & 1 & 9 & 0 & 0 & 0.5 & 1 & 9 & -0.5 & 0 \\
\hline & & \multicolumn{4}{|c|}{ Indexen $\mathrm{N} 10.02$} & Real. & \multicolumn{4}{|c|}{ Indexen N11.01 } & \multirow[t]{2}{*}{ Real. } \\
\hline Fysiotoop & Opp & GVG & GLG & DS & $Z \mathrm{G}$ & & GVG & GLG & DS & $\mathrm{ZG}$ & \\
\hline HzDV_PS012 VN & 1.01 & 0.5 & 1 & 0 & -0.94 & 0 & -0.5 & 1 & 0 & -0.44 & 0 \\
\hline HzDV_PS012 VO & 0.58 & 0.68 & 1 & 0.54 & -1 & 0 & -0.5 & 1 & 0 & -1 & 0 \\
\hline RiZD_PS031C DR & 1.64 & 1 & 1 & 0.57 & -0.5 & 0 & -0.19 & 1 & 0 & 0 & 0 \\
\hline RiZD_PS031C VO & 1.62 & 0.6 & 1 & 0.29 & -0.5 & 0 & -0.5 & 1 & 0 & 0 & 0 \\
\hline RiZN_PS012 DR & 1.66 & 0.95 & 1 & 0.38 & -1 & 0 & -0.34 & 1 & 0 & -0.63 & 0 \\
\hline RiZN_PS013 NA & 5.27 & 0.32 & 1 & 0 & -0.5 & 0 & -0.5 & 1 & 0 & 0 & 0 \\
\hline RiZN_PS013 VO & 0.55 & 0.5 & 1 & 0 & -0.5 & 0 & -0.5 & 1 & 0 & 0 & 0 \\
\hline RiZN_PS013 ZN & 1.12 & 0.03 & 1 & 0 & -0.5 & 0 & -0.54 & 1 & 0 & 0 & 0 \\
\hline RiZR_PS013 NA & 0.98 & 0.29 & 1 & 0 & -0.5 & 0 & -0.5 & 1 & 0 & 0 & 0 \\
\hline RiZR_PS014 NA & 0.53 & 0.5 & 1 & 0 & -0.5 & 0 & -0.5 & 1 & 0 & 0 & 0 \\
\hline RiZR_PS014 ZN & 1.56 & 0 & 1 & 0 & -0.83 & 0 & -0.55 & 1 & 0 & -0.35 & 0 \\
\hline RiZR_PS016 ZN & 0.19 & -0.5 & 1 & 0 & 0 & 0 & -1 & 1 & 0 & 0 & 0 \\
\hline RiZV_PS014 NA & 1.31 & 0.35 & 1 & 0 & -0.5 & 0 & -0.5 & 1 & 0 & 0 & 0 \\
\hline RiZV_PS014 VO & 0.87 & 0.58 & 1 & 0.11 & -0.5 & 0 & -0.5 & 1 & 0 & 0 & 0 \\
\hline RiZV_PS014 ZN & 1.16 & 0.14 & 1 & 0 & -0.5 & 0 & -0.53 & 1 & 0 & 0 & 0 \\
\hline RiZW_PS013 VO & 5.44 & 0.5 & 1 & 0.25 & -0.5 & 0 & -0.5 & 1 & 0 & 0 & 0 \\
\hline RiZW_PS014 VO & 1.84 & 0.5 & 1 & 0.25 & -0.5 & 0 & -0.5 & 1 & 0 & 0 & 0 \\
\hline
\end{tabular}


Wageningen Environmental Research Postbus 47

6700 AA Wageningen

T 0317480700

www.wur.nl/environmental-research

Wageningen Environmental Research

Rapport 2917

ISSN 1566-7197
De missie van Wageningen University \& Research is 'To explore the potential of nature to improve the quality of life'. Binnen Wageningen University \& Research bundelen Wageningen University en gespecialiseerde onderzoeksinstituten van Stichting Wageningen Research hun krachten om bij te dragen aan de oplossing van belangrijke vragen in het domein van gezonde voeding en leefomgeving. Met ongeveer 30 vestigingen, 5.000 medewerkers en 10.000 studenten behoort Wageningen University \& Research wereldwijd tot de aansprekende kennisinstellingen binnen haar domein. De integrale benadering van de vraagstukken en de samenwerking tussen verschillende disciplines vormen het hart van de unieke Wageningen aanpak. 



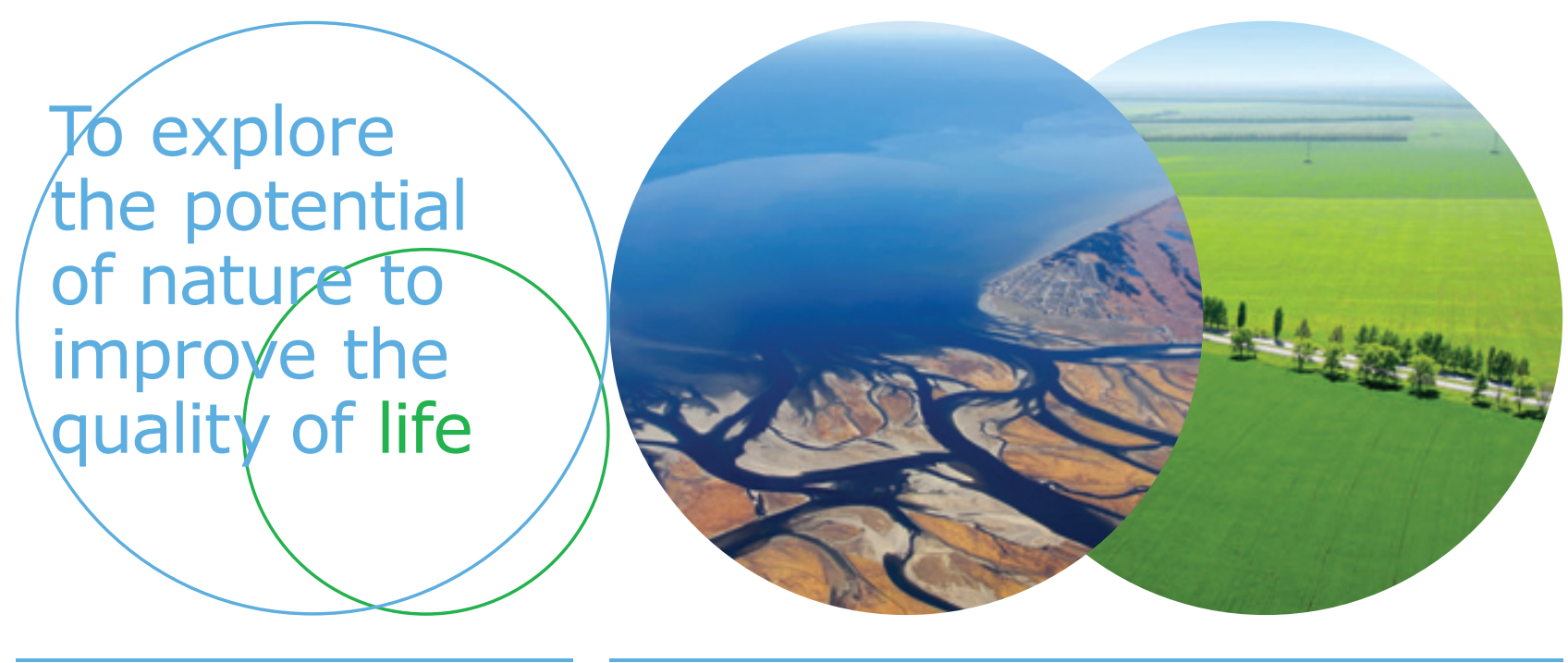

Wageningen Environmental Research Postbus 47

$6700 \mathrm{AB}$ Wageningen

T 317480700

www.wur.nl/environmental-research

Rapport 2917

ISSN 1566-7197
De missie van Wageningen University \& Research is 'To explore the potential of nature to improve the quality of life'. Binnen Wageningen University \& Research bundelen Wageningen University en gespecialiseerde onderzoeksinstituten van Stichting Wageningen Research hun krachten om bij te dragen aan de oplossing van belangrijke vragen in het domein van gezonde voeding en leefomgeving. Met ongeveer 30 vestigingen, 5.000 medewerkers en 10.000 studenten behoort Wageningen University \& Research wereldwijd tot de aansprekende kennisinstellingen binnen haar domein. De integrale benadering van de vraagstukken en de samenwerking tussen verschillende disciplines vormen het hart van de unieke Wageningen aanpak. 